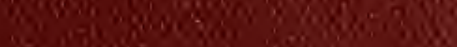

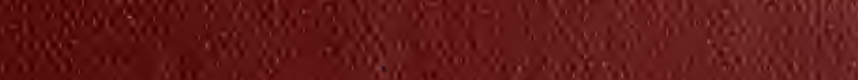

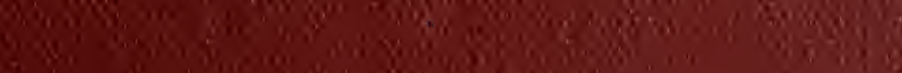

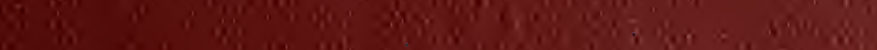

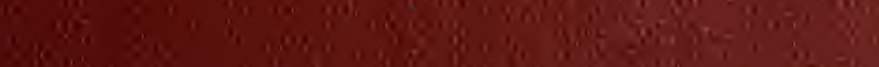
a

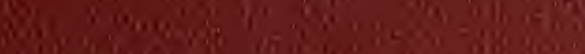

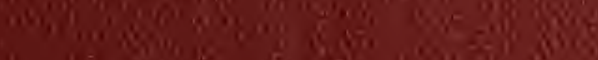

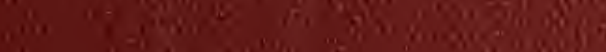
1. as

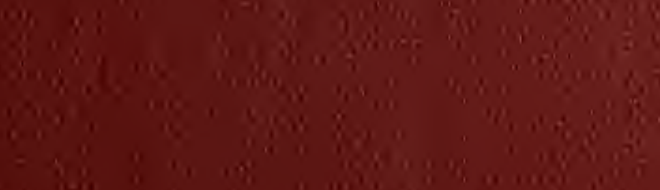

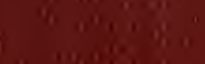<smiles>[Ge]c1c#cc#cc1</smiles>

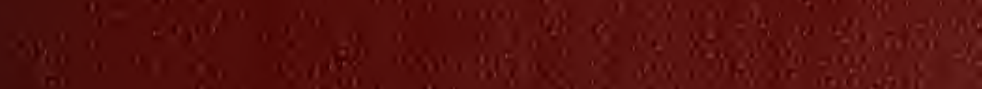

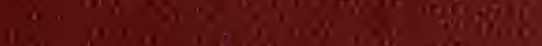

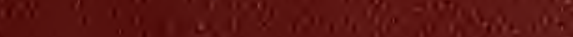

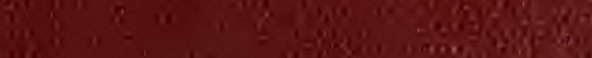

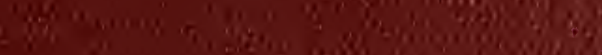

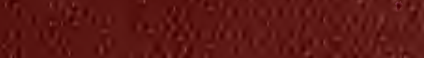
G.

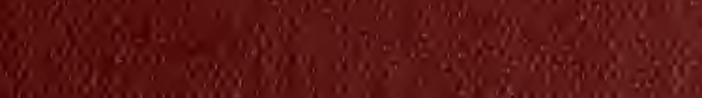

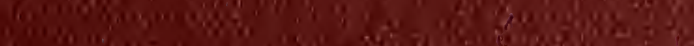

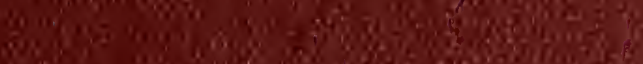

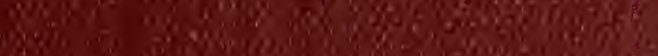

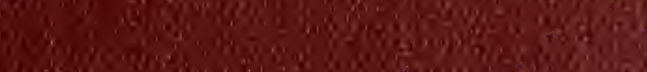

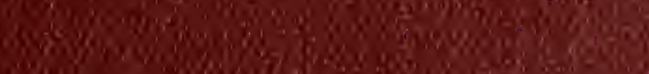

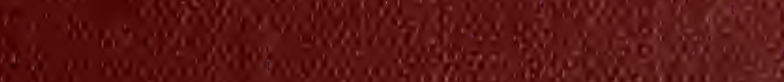

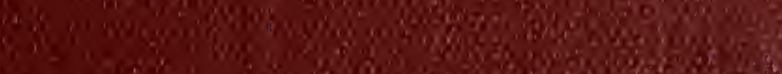



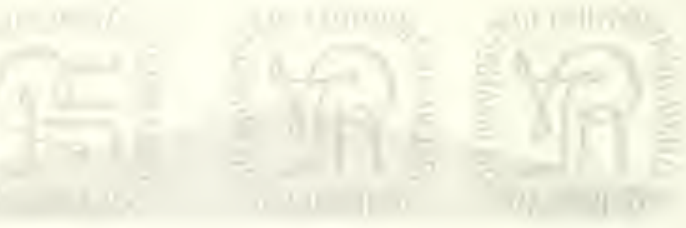

Digitized by the Internet Archive in 2008 with funding from Microsoft Corporation 


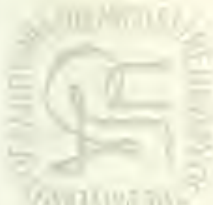

Q⿳⺈⿴囗十⺝⿱艹
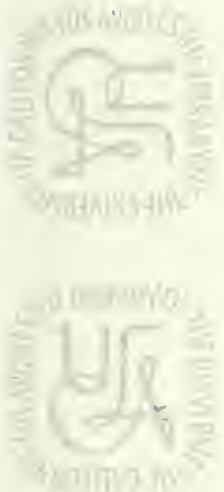

14 Dnutrit.
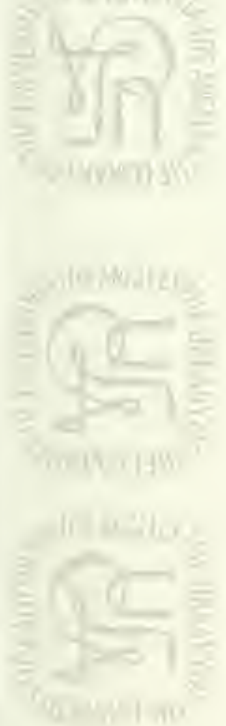

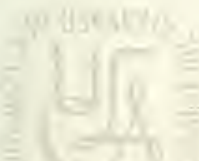

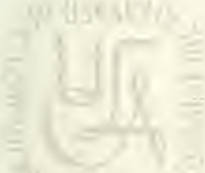

$96 m+17+114$
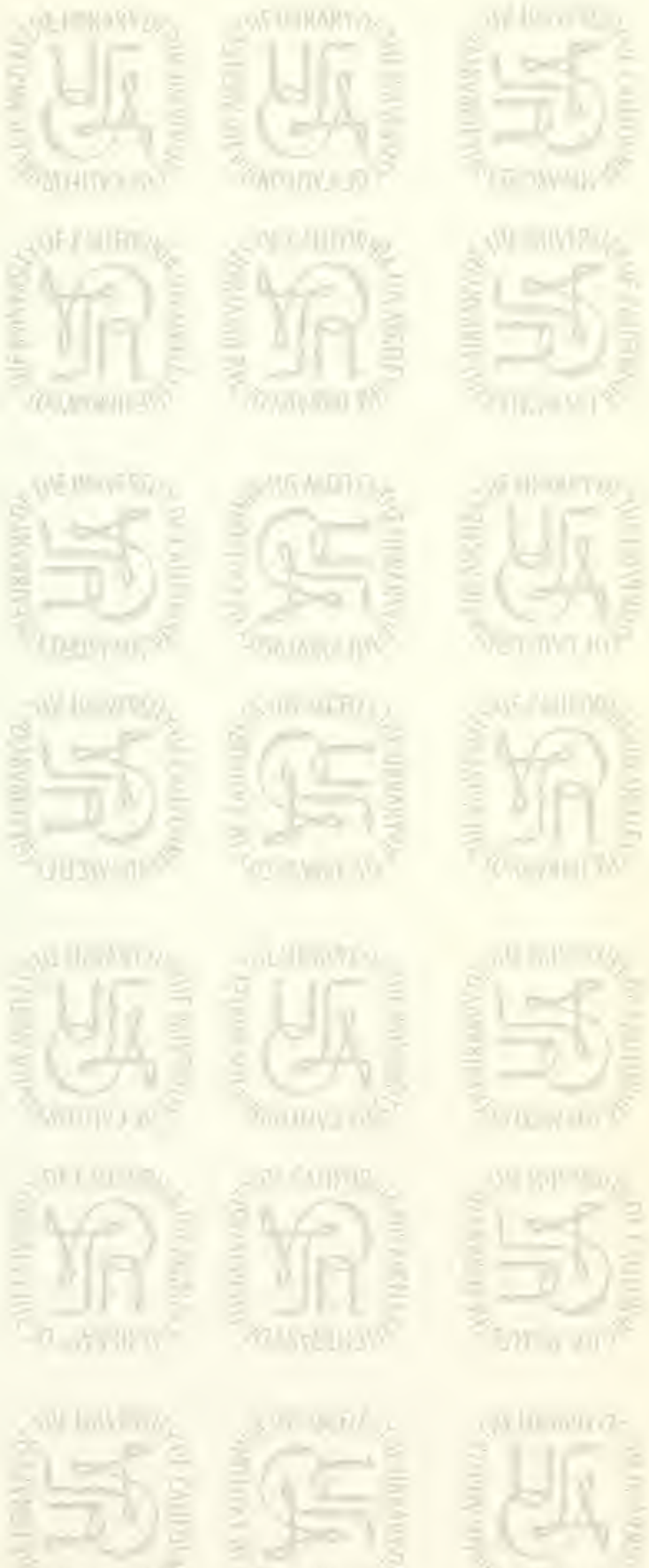

y.til witin-

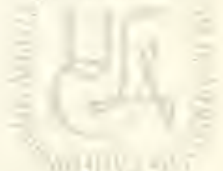







\section{TABOO AND GENETICS}

A STUDY OF THE BIOLOGICAL SOCIOLOGICAL AND PSYCHOLOGICAL FOUNDATION OF THE FAMILY 



\section{Taboo and Genetics}

A STUDY OF THE BIOLOGICAL, SOCIOLOGICAL AND PSYCHOLOGICAL FOUNDATION OF THE FAMILY

BY

M. M. KNIGHT, Ph.D.

IVA LOWTHER PETERS, Ph.D. PHYLLIS BLANCHARD, PH.D.

Author of The Adolescent Girl

LONDON :

KEGAN PAUL, TRENCH, TRUBNER \& CO., LTD. NEW YORK: MOFFAT, YARD \& CO. 

DEDICATED TO OUR FRIEND AND TEACHER, FRANK HAMILTON HANKINS 



\section{PREFACE}

Scientific discovery, especially in biology, during the past two decades has made necessary an entire restatement of the sociological problem of sex. Ward's so-called "gynæcocentric" theory, as sketched in Chapter I4 of his Pure Sociology, has been almost a bible on the sex problem to sociologists, in spite of the fact that modern laboratory experimentation has disproved it in almost every detail. While a comparatively small number of people read this theory from the original source, it is still being scattered far and wide in the form of quotations, paraphrases, and interpretations by more popular writers. It is therefore necessary to gather together the biological data which are available from technical experimentation and medical research, in order that its social implications may be utilized to show the obsoleteness of this older and unscientific statement of the sex problem in society.

In order to have a thoroughly comprehensive survey of the institutions connected with sexual relationships and the family and their entire significance for human life, it is also necessary to approach them from the ethnological and psychological points of view. The influence of vii 
the primitive sex taboos on the evolution of the social mores and family life has received too little attention in the whole literature of sexual ethics and the sociology of sex. That these old customs have had an inestimable influence upon the members of the group, modern psychology has recently come to recognize. It therefore seems advantageous to include these psychological findings in the same book with the discussion of the sex taboos and other material with which it must so largely deal.

These fields-biology, ethnology, and psychology - are so complicated and so far apart technically, although their social implications are so closely interwoven, that it has seemed best to divide the treatment between three different writers, each of whom has devoted much study to his special phase of the subject. This leads to a very simple arrangement of the material. The first part deals with the physical or biological basis of the sex problem, which all societies from the most primitive to the most advanced have had and still have to build upon. The second part deals with the various ideas man has developed in his quest for a satisfactory adaptation of this physical basis to his own requirements. Part three attempts to analyze the effect of this long history of social experimentation upon the human psyche in its modern social milieu. 
In the social evolution of the human mind, the deepest desires of the individual have been often necessarily sacrificed to the needs of the group. Sometimes they have been unnecessarily sacrificed, since human intelligence is, unfortunately, not omniscient. Nevertheless, the sum total of human knowledge has now become great enough so that it is at least well to pause and take account of its bearing on the age-old problem of family life, in order that our evolution henceforth may be guarded by rational control rather than trial and error in so far as is possible. Such a summarization of our actual knowledge of the biology, sociology and psychology of the foundations of the family institution this book aims to present, and if it can at the same time suggest a starting point for a more rationalized system of social control in this field, its purpose will have been accomplished.

The Authors. 



\section{CONTENTS}

\section{PART I}

By M. M. KNight, FH.D.

\section{The New Biology and the Sex Problem in Society}

CHAPTER

I. The Problem Defined . . • 3

What is sex ? A sexual and mixed reproduction.

Origin of sexual reproduction. Advantage of sex in chance of survival. Germ and body cells. Limitations of biology in social problems. Sex always present in higher animals. Sex in mammals - the problem in the human species. Application of the laboratory method.

II. SEx IN TERMS OF INTERNAL SECRETIONS Continuity of germ plasm. The sex chromosome. The internal secretions and the sex complex. The male and the female type of body. How removal of sex glands affects body type. Sex determination. Share of the egg and sperm in inheritance. The nature of sexsexual selection of little importance. The four main types of secretory systems. Sex and sex instincts of rats modified by surgery. Dual basis for sex. Opposite sex basis in every individual. The Free-Martin cattle. Partial reversal of sex in human species.

III. Sex and Sex Differences as Quanti-

\section{TATIVE.}

Intersexes in moths. Bird intersexes. Higher metabolism of males. Quantitative difference between sex factors. Old ideas of intersexuality. Modern surgery and human intersexes. Quantitative theory a Mendelian explanation. Peculiar complication in the case of man. Chemical life-cycles of the sexes. Functional-reproductive period and the sex problem. Relative significance of physiological sex differences. 
IV. Sex Specialization and Group Sur-

Adaptation and specialization. Reproduction a group-not an individual problem. Conflict between specialization and adaptation. Intelligence makes for economy in adjustment to environment. Reproduction, not production, the chief factor in the sex problem.

V. Racial Degeneration and the NecesSITY FOR RATIONALIZATION OF THE

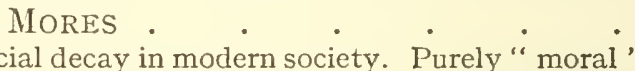

Racial decay in modern society. Purely " moral "
control dysgenic in civilized society. New machinery for social control. Mistaken notion that reproduction is an individual problem. Economic and other factors in the group problem of reproduction.

\section{PART II}

By Iva Lowther Peters, Ph.D.

\section{The Institutionalized Sex Taboo}

I. The Primitive Attitude Toward Sex AND WOMANHOOD . Primitive social control. Its rigidity. Its neces-
sity. The universality of this control in the form of taboos. Connection between the universal attitude of primitive peoples toward woman as shown in the Institutionalized Sex Taboo and the magico-religious belief in Mana. Relation of Mana to Taboo. Discussion of Sympathetic Magic and the associated idea of danger from contact. Difficulties in the way of an inclusive definition of Taboo. Its dual nature. Comparison of concepts of Crawley, Frazer, Marett, and others. Conclusion that Taboo is Negative Mana. Contribution of modern psychology to the study of Taboo. Freud's analogy between the dualistic attitude toward the tabooed object and the ambivalence of the emotions. The understanding of this dualism together with the primitive belief in Mana and Sympathetic Magic 


\section{CONTENTS}

xiii

CHAPTER

explains much in the attitude of man toward woman. The vast amount of evidence in the taboos of many peoples of dualism in the attitude toward woman. Possible physiological explanation of this dualistic attitude of man toward woman found in a period before self-control had in some measure replaced social control, in the reaction of weakness and disgust following sex festivals.

iI. From the Dawn of History: Woman

\section{AS SAINT AND WITCH}

Taboos of first chapter indicate that in the early ages the fear of contamination by woman predominated. Later emphasis fell on her mystic and uncanny power. Ancient fertility cults. Temple prostitution, dedication of virgins, etc. Ancient priestesses and prophetesses. Medicine early developed by woman added to belief in her power. Woman's psychic quality of intuition : its origin-theories-conclusion that this quality is probably physiological in origin, but aggravated by taboo repressions. Transformation in attitude toward woman in the early Christian period. Psychological reasons for the persistence in religion of a Mother Goddess. Development of the Christian concept. Preservation of ancient woman cults as demonology. Early Christian attitude toward woman as unclean and in league with demons. Culmination of belief in demonic power of woman in witchcraft persecutions. All women affected by the belief in witches and in the uncleanness of woman. Gradual development on the basis of the beliefs outlined of an ideally pure and immaculate Model Woman.

III. The DuAlism in MOdern LifE: THE

InSTITUTIONAL TABOO • . • The Taboo and modern institutions. Survival of ideas of the uncleanness of woman. Taboo and the family. The "good " woman. The "bad" woman. Increase in the number of women who do not fit into the ancient classifications.

IV. Dysgenic Influences of the InstituTIONAL TABOO

PAGE 
CHAPTER

education of girls a dysgenic influence. Prostitution and the family. Influence of ancient standards of "good " and "bad." The illegitimate child. Effect of fear, anger, etc., on posterity. The attitude of economically independent women toward marriage.

\section{PART III}

By Phyllis Blanchard, Ph.D.

The Sex Problem in the Light of Modern PSYCHOLOGY

I. Sex in Terms of Modern Psychology

Bearing of modern psychology on the sex problem. Conditioning of the sexual impulse. Vicarious expression of the sexual impulse. Unconscious factors of the sex life. Taboo control has conditioned the natural biological tendencies of individuals to conform to arbitrary standards of masculinity and femininity. Conflict between individual desires and social standards.

\section{How Our Institutions Fit Tndividual} Sex Psychology . . . .

Social institutions controlling sex activities based on the assumption that all women are adapted to as well as specialized for reproduction. Neurotic tendencies which unfit women for marriage-the desire for domination. Sexual anæsthesia another neurotic trait which interferes with marital harmony. The conditioning of the sexual impulse to the parent ideal and the erotic fetish as factors which determine mating. Homosexual tendencies and their part in the sex problem. The conflict between the desire for marriage and egoistic ambitions. The social regulations from the viewpoint of individual psychology. 


\section{CONTENTS}

III. Dysgenic Nature of Certain Factors of Sex Psychology and Necessity FOR a Social Therapy . • . 238

mating determined by unconscious psychological motives instead of eugenic considerations. Some of the best male and female stock refusing marriage and parenthood. The race is reproduced largely by the inferior and average stocks and very little by the superior stock. As a therapeutic measure, society should utilize psychological knowledge as a new method of control. Romantic love and conjugal love-a new ideal of love. The solution of the conflict between individual and group interests. 



\section{PART I}

THE NEW BIOLOGY AND THE SEX PROBLEM IN SOGIETY BY

M. M. KNIGHT, PH.D. 



\section{CHAPTER I}

THE PROBLEM DEFINED

What is sex? Asexual and mixed reproduction; Origin of sexual reproduction; Advantage of sex in chance of survival ; Germ and body cells ; Limitations of biology in social problems; Sex always present in higher animals; Sex in mammals; The sex problem in the human species; Application of laboratory method.

Sex, like all complicated phenomena, defies being crowded into a simple definition. In an animal or plant individual it is expressed by and linked with the ability to produce egg- or sperm-cells (ova or spermatozoa). Sexual reproduction is simply the chain of events following the union of the egg and sperm to produce a new individual. Looked at from another angle, it is that sort of reproduction which requires two differentiated individuals: the male, which produces spermatoza, and the female, which produces ova. In the case of very simple forms, it would be simply the union or conjugation of a male and a female individual and the reproductive process involved. Where there is no differentiation into male and fernale there is no sex. 
An individual which produces both spermand egg-cells within its body is termed an hermaphrodite. Very few hermaphrodites exist among the vertebrates, although they may be found in one or two species (e.g., the hagfish). There are no truly hermaphroditic mammals, i.e., individuals in which both the male and the female germ cells function, except perhaps in rare instances.

Sexless or asexual reproduction assumes various forms. What is usually considered the most primitive of these is fission or simple division, in which the cell divides into two equal, identical parts. There is of course no suggestion of sex here. It is fairly safe to assume that life began thus in the world, as neuter or sexless -i.e., with no suggestion of either maleness or femaleness.*

*This asexual type of reproduction has been misinterpreted by a whole school of non-biological writers, who have followed the lead of Lester F. Ward, in his classification of these neuterorganisms as females. Ward says ("Pure Sociology," Ch. I4): "It does no violence to language or science to say that life begins with the female organism and is carried on a long distance by means of females alone. In all the different forms of asexual reproduction from fission to parthenogenesis, the female may in this sense be said to exist alone and perform all the functions of life including reproduction. In a word, life begins as female" (p. 3I3). Adding to this statement the assertion that the male developed at first as a mere parasite, in the actual, physical sense, Ward proceeds to build up his famous Gynæcocentric Theory, which is familiar to all students of social science, and need not be elaborated here. It is obvious that a thorough biological knowledge destroys the fundamental concept on which this theory is founded, for there is no doubt that life begins as neuter or sexless, and not as female. 
There are a number of other forms of asexual reproduction, or the "vegetative type " (Abbott's term, which includes fission, budding, polysporogonia and simple spore formation). Budding (as in yeast) and spore formation are familiar to us in plants. Such forms are too distant from man, in structure and function, for profitable direct comparison. Especially is this true with respect to sex, which they do not possess.

Parthenogenesis includes very diverse and anomalous cases. The term signifies the ability of females to reproduce in such species for one or a number of generations without males. Many forms of this class (or more strictly, these classes) have apparently become specialized or degenerated, having once been more truly sexual. Parthenogenesis (division and development of an egg without the agency of male sperm) has been brought about artificially by Jacques Loeb in species as complicated as frogs. $(I, 2$.$) All the frogs produced were males, so$ that the race (of frogs) could not even be theoretically carried on by that method.

The origin of sexual reproduction in animals must have been something as follows: The first method of reproduction was by a simple division of the unicellular organism to form two new individuals. At times, a fusion of two independent individuals occurred. This was 
known as conjugation, and is seen among Paramecia and some other species to-day. Its value is probably a reinvigoration of the vitality of the individual. Next there was probably a tendency for the organism to break up into many parts which subsequently united with each other. Gradually some of these uniting cells came to contain more food material than the others. As a result of their increased size, they possessed less power of motion than the others, and in time lost their cilia (or flagella) entirely and were brought into contact with the smaller cells only by the motion of the latter. Finally, in colonial forms, most of the cells in the colony ceased to have any share in reproduction, that function being relegated to the activities of a few cells which broke away and united with others similarly adrift. These cells functioning for reproduction continued to differentiate more and more, until large ova and small, motiles permtozoa were definitely developed.

The clearest evidences as to the stages in the evolution of sexual reproduction is found in the plant world among the green algæ. (3.), In the lower orders of one-celled algæ, reproduction takes place by simple cell division. In some families, this simple division results in the production of several new individuals instead of only two from each parent cell. A slightly 


\section{TABOO AND GENETICS}

different condition is found in those orders where the numerous cells thus produced by simple division of the parent organism unite in pairs to produce new individuals after a brief independent existence of their own. These free-swimming cells, which apparently are formed only to reunite with each other, are called zoospores, while the organism which results from their fusion is known as a zygospore. The zygospore thus formed slowly increases in size, until it in its turn develops a new generation of zoöspores. In still other forms, in place of the zoöspores, more highly differentiated cells, known as eggs and sperms, are developed, and these unite to produce the new individuals. Both eggs and sperms are believed to have been derived from simpler ancestral types of ciliated cells which were similar in structure and closely resembled zoöspores.*

Having once originated, the sexual type of reproduction possessed a definite survival value which assured its continuation. Sex makes possible a crossing of strains, which evidently possesses some great advantage, since the few simple forms which have no such division of reproductive functions have undergone no great

*'This evidence, which points to the conclusion that in the early origin of sexual reproduction the males and females were differentiated and developed from a uniform type of ancestral cell, quite controverts Ward's point that the male originated as a kind of parasite. 
development and all the higher, more complicated animals are sexual. This crossing of strains may make possible greater variety, it may help in crossing out or weakening variations which are too far from the average, or both.

Schäfer (4) thinks that an exchange of nuclear substance probably gives a sort of chemical rejuvenation and very likely stimulates division. At any rate, the groups in which the reproductive process became thus partitioned between two kinds of individuals, male and female, not only survived, but they underwent an amazing development compared with those which remained sexless.

There came a time in the evolution of the groups possessing sexual reproduction, when increasing specialization necessitated the division into reproductive and non-reproductive cells. When a simple cell reproduces by dividing into two similar parts, each developing into a new individual like the parent, this parent no longer exists as a cell, but the material which composed it still exists in the new ones. The old cell did not " die "-no body was left behind. Since this nuclear substance exists in the new cells, and since these generations go on indefinitely, the cells are in a sense " immortal " or deathless. In a one-celled individual, there is no distinction between germinal and bodily functions. In the more complicated organisms, however, there are 
innumerable kinds of cells, a few (the germ cells) specialized for reproduction, the others forming the body which eats, moves, sees, feels, and in the case of man, thinks. But the germ-cells or germplasm continue to be immortal or deathless in the same sense as in the simplest organisms. The body, in a historical sense, grew up around the germ-cells, taking over functions a little at a time, until in the higher animals nutrition and other activities and a large part even of the reproductive process itself is carried on by bodycells.

When we think of a man or woman, we think of an individual only one of whose innumerable activities-reproduction-is carried on by germcells, and this one only at the very beginning of the life of a new individual. Human societies, needless to remark, are not organized by germplasms, but by brains and hands-composed of body cells. If these brains and hands-if human bodies-did not wear out or become destroyed, we should not need to trouble ourselves so much about the germplasm, whose sole function in human society is to replace them.

Since the individual human bodies and minds which seek after the things to which we mortals attach value-moral worth, esthetic and other pleasure, achievement and the like-do have to be replaced every few years, the germplasms from which new individuals must come have 
always been and always will be of fundamental importance. It is always the product of the germplasm which concerns us, and we are interested in the germ-cells themselves only in relation to their capacity to produce individuals of value to society.

So let us not go erring about in the philosophical ether, imagining that because the amueba may not be specialized for anything over and above nutrition and reproduction that these are necessarily the "main business" or " chief ends" of human societies. Better say that although we have become developed and specialized for a million other activities we are still bound by those fundamental necessities. As to "Nature's purposes" about which the older sex literature has had so much to say, the idea is essentially religious rather than scientific. If such " purposes " indeed exist in the universe, man evidently does not feel particularly bound by them. We do not hesitate to put a cornfield where "Nature" had a forest, or to replace a barren hillside by the sea with a city.

Necessities and possibilities, not "purposes" in nature, claim our attention-reproduction being one of those embarrassing necessities, viewed through the eyes of man, the one evaluating animal in the world. Thus in reasoning from biology to social problems, it is fundamental to remember that man as an animal is tremen- 
dously differentiated in functions, and that most of the activities we look upon as distinctively human depend upon the body rather than the germ-cells.

It follows that biology is the foundation rather than the house, if we may use so crude a figure. The solidity of the foundation is very important, but it does not dictate the details as to how the superstructure shall be arranged.

Civilization would not be civilization if we had to spend most of our time thinking about the biological basis. If we wish to think of "Nature's" proscriptions or plans as controlling animal life, the anthropomorphism is substantially harmless. But man keeps out of the way of most of such proscriptions, has plans of his own, and has acquired considerable skill in varying his projects without running foul of such biological prohibitions.

It is time to abandon the notion that biology prescribes in detail how we shall run society. True, this foundation has never received a surplus of intelligent consideration. Sometimes human societies have built so foolishly upon it that the result has been collapse. Somebody is always digging around it in quest of evidence of some vanished idyllic state of things which, having had and discarded, we should return to. This little excursion into biology is made in the full consciousness that social mandates are not 
to be found there. Human projects are the primary material of social science. It is indispensable to check these against biological fact, in order to ascertain which are feasible and which are not. The biological basis may help in explaining old social structures or in planning new ones; but much wild social theory has been born of a failure to appreciate the limitations of such material.

All the so-called higher animals, mammals and others, are divided into two sexes, male and female. Besides the differentiation of germ-cells there are rather obvious differences in the bodies of the two sexes. In common with many other mammals, the human male has a larger and stronger body, on an average, than has the human female. This is true also of the anthropoid apes, the species which most resemble man physically and are commonly supposed to be his nearest blood relatives in the animal kingdom. It has been true of man himself as far back as we have any records.

Such differences are only superficial-the real ones go deeper. We are not so much interested in how they originated in the world as in how they do come about in the individual. At least, we can come a good deal nearer ascertaining the latter than the former. In either case, our real purpose is to determine as nearly as possible what the unlikeness really consists 
of and so help people to sensibly make up their minds what can be done about it.

To define sex with rigid accuracy as the term applies to human beings, it is necessary to tell what it is in mammals, since man is a mammal. The presence of distinct body-cells is not peculiar to mammals, but there is one respect in which these latter are quite different from non-mammals: A mammalian individual, beginning like a non-mammal with a fertilized egg, has a period of intra-maternal development which a non-mammal has not. That is, a non-mammalian is a fertilized egg plus its parental (or extra-parental) environment; but a mammalian individual is a fertilized egg, phus its intra-maternal environment, plus its nonparental environment.

Here in a nutshell is the biological basis of sex problem in human society. Human individuals do wear out and have to be replaced by reproduction. In the reproductive process, the female, as in mammals generally, is specialized to provide an intra-maternal environment (approximately nine months in the human species) for each new individual, and lactation or suckling afterward. The biological phase of the sex problem in society consists in studying the nature of that specialization. From the purely sociological standpoint, the sex problem concerns the customs and institutions which 
have grown up or may grow up to meet the need of society for reproduction.

The point which most concerns us is in how far biological data can be applied to the sex problem in society. Systematic dissections or breeding experiments upon human beings, thought out in advance and under control in a laboratory, are subject to obvious limitations. Surgical operations, where careful data are kept, often answer the same purpose as concerns some details; but these alone would give us a fragmentary record of how a fertilized egg becomes a conscious human being of one sex or the other. The practice of medicine often throws light on important points. Observation of abnormal cases plays its part in adding to our knowledge. Carefully compiled records of what does occur in inheritance, while lacking many of the checks of planned and controlled experiments, to some extent take the place of the systematic breeding possible with animals. At best, however, the limitations in experimentation with human subjects would give us a rather disconnected record were it not for the data of experimental biology.

How may such biological material be safely used? Indiscriminately employed, it is worse than useless - it can be confusing or actually misleading. It is probably never safe to say, or even to infer directly, that because of this 


\section{TABOO AND GENETICS}

or that animal structure or behaviour we should do thus and so in human society. On this point sociology-especially the sociology of sexmust frankly admit its mistakes and break with much of its cherished past.

The social problem of sex consists of fitting the best possible institutions on to the biological foundation as we find it in the human species. Hence all our reasoning about which institution or custom is preferable must refer directly to the human bodies which compose society. We can use laboratory evidence about the bodies of other animals to help us in understanding the physical structure and functions of the human body; but we must stop trying to apply the sex-ways of birds, spiders or even cows (which are at least mammals) to human society, which is not made up of any of these.

It is possible to be quite sure that some facts carefully observed about mammals in a biological laboratory apply to similar structures in man, also a mammal. Because of this relationship, the data from medicine and surgery are priceless. Thus we are enabled to check up our systematic experimental knowledge of animals by an ascertained fact here and there in the human material, and to get a fairly exact idea of how great the correspondence actually is. Gaps thus filled in are narrow enough, and our certainty of the ground on either side sufficiently 
great, to give a good deal of justifiable assurance.

If we use our general biological evidence in this way, merely to help in clearing up points about human biology, we need not be entirely limited to mammals. Some sex phenomena are quite general, and may be drawn from the sexual species most convenient to study and control in experiments. When we get away from mammalian forms, however, we must be very sure that the cases used for illustrations are of general application, are similar in respect to the points compared, or that any vital differences are understood and conscientiously pointed out.

Too much stress cannot be laid upon the point that such animal data, carefully checked up with the human material, cannot safely be used for any other purpose than to discover what the facts are about the human body. When the discussion of human social institutions is taken up in Part II, the obvious assumption will always be that these rest upon human biology, and that we must not let our minds wander into vague analogies concerning birds, spiders or crustacea.

\section{BIBLIOGRAPHY FOR CHAPTER I}

I. Loeb, Jacques. Artificial Parthenogenesis and Fertilization. Chicago, Igr3. 


\section{TABOO AND GENETICS}

2. Loeb, Jacques. The Organism as a Whole. N.Y., I9I6, p. I25-brief summary of results of (I).

3. Bower, Kerr \& Agar. Sex and Heredity. N.Y., I9I9, II9 pp.

4. Schäfer, E. A. Nature, Origin and Maintenance of Life. Science, n. s., Vol. 36, pp. 306 f., IgI2.

5. Guyer, M. F. Being Well-Born. Indianapolis, IgI6. p. I23. 


\section{CHAPTER II}

\section{SEX IN TERMS OF INTERNAL SECRETIONS}

Continuity of germplasm; The sex chromosome; The internal secretions and the sex complex; The male and the female type of body; How removal of sex glands affects body type; Sex determination; Share of egg and sperm in heredity; Nature of sex-sexual selection of little importance; The four main types of secretory systems; Sex and sex-instincts of rats modified by surgery; Dual basis for sex; Oppositesex basis in every individual ; The Free-Martin cattle; Partial reversal of sex in man.

In Chapter I, the "immortality" of the protoplasm in the germ cells of higher animals, as well as in simpler forms without distinct bodies, was mentioned. In these higher animals this protoplasm is known as germplasm, that in body cells as somatoplasm.

All that is really meant by "immortality" in a germplasm is continuity. That is, while an individual may consist of a colony of millions of cells, all of these spring from one cell and it a germ cell-the fertilized ovum. This first divides to form a new group of germ cells, which are within the embryo or new body when it begins to develop, and so on through indefinite 


\section{TABOO AND GENETICS}

generations. Thus the germ cells in an individual living to-day are the lineal descendants, by simple division, of the germ cells in his ancestors as many generations, or thousands of generations, ago as we care to imagine. All the complicated body specializations and sex phenomena may be regarded as super-imposed upon or grouped around this succession of germ cells, continuous by simple division.

The type of body in each generation depends upon this germplasm, but the germplasm is not supposed to be in any way modified by the body (except, of course, that severe enough accidents might damage it). Thus we resemble our parents only because the germplasm which directs our development is a split-off portion of the same continuous line of germ cells which directed their development, that of their fathers, and so on back. This now universally accepted theory is called the "continuity of the germplasm."

It will be seen at once that this seems to preclude any possibility of a child's inheriting from its parents anything which these did not themselves inherit. The bodies of each generation are, so to speak, mere "buds" from the continuous lines of germplasm. If we develop our muscles or our musical talent, this development is of the body and dies with it, though the physical basis or capacity we ourselves inherited 
is still in the germplasm and is therefore passed along to our children. We may also furnish our children an environment which will stimulate their desire and lend opportunity for similar or greater advancement than our own. This is social inheritance, or the product of environment - easy to confuse with that of heredity and very difficult to separate, especially in the case of mental traits.

It will likewise become clear as we proceed that there is no mechanism or relationship known to biology which could account for what is popularly termed " pre-natal influence." A developing embryo has its own circulation, so insulated from that of the mother that only a few of the most virulent and insidious disease germe can ever pass the barrier. The general health of the mother is of utmost importance to the vitality, chances of life, constitution and immunity from disease of the unborn child. Especially must she be free from diseases which may be communicated to the child either before or at the time of birth. This applies particularly to gonorrhœa, one of the most widely prevalent as well as most ancient of maladies, and syphilis, another disastrous and very common plague which is directly communicable. As to "birthmarks" and the like being directly caused by things the mother has seen or thought about, such beliefs seem to be founded on a few re- 


\section{TABOO AND GENETICS}

markable pure coincidences and a great deal of folk-lore.

Reproduction in its simplest form is, then, simply the division of one cell into two parts, each of which develops into a replica of the original. Division is also the first stage in reproduction in the most complicated animal bodies. To get an idea of what takes place in such a division we must remember that a cell consists of three distinct parts: (a) the protoplasm or cytoplasm, (b) the nucleus, and (c) a small body known as the centrosome which need not be discussed here.

When a cell division takes place, the nucleus breaks up into a number of thread-like portions which are known as chromosomes. There are supposed to be 24 pairs, or 48 , in the human cell. All the evidence indicates that these chromosomes carry the "factors " in inheritance which produces the characters or characteristics of the individual body.

In mitosis or ordinary cell division, these chromosomes split lengthwise, so that the new cells always have the same number as the original one. When the germ-cells of the male and female make the division which marks the first step in reproduction, however, the process is different. Half the chromatin material passes into each of the two cells formed. This is called maturation, or the maturation division, and the 
new cells have only half the original number of chromosomes. Each of these divides again by mitosis (the chromosomes splitting lengthwise), the half or haploid number remaining. The result is the gametes (literally " marrying cells "-from the Greek gamé, signifying marriage). Those from the male are called sperms or spermatozoa and those from the female eggs or ova. (The divisions to form ova present certain complications which need not be taken up in detail here.) Of the 24 chromosomes in each sperm or egg we are here concerned with only one, known as the sex chromosome because, in addition to transmitting other characteristics, it determines the sex of the new individual.

Neither the ovum nor the spermatozoon (the human race is referred to) is capable alone of developing into a new individual. They must join in the process known as fertilization. The sperm penetrates the egg (within the body of the female) and the 24 chromosomes from each source, male and female, are re-grouped in a new nucleus with 48 chromosomes-the full number. The chances are half and half that the new individual thus begun will be of a given sex, for the following reason: There is a structural difference, supposed to be fundamentally chemical, between the cells of a female body and those of a male. The result is that the gametes (sperm and eggs) they respectively produce in 
maturation are not exactly alike as to chromosome composition. All the eggs contain what is known as the " $\mathrm{X}$ " type of sex chromosome. But only half the male sperm have this type -in the other half is found one of somewhat different type, known as "Y." (This, again, is for the human species-in some animals the mechanism and arrangement is somewhat different.) If a sperm and egg both carrying the $\mathrm{X}$-type of chromosome unite in fertilization, the resulting embryo is a female. If an $\mathrm{X}$ unites with a $\mathrm{Y}$, the result is a male. Since each combination happens in about half the cases, the race is about half male and half female.

Thus sex is inherited, like other characters, by the action of the chromatin material of the cell nucleus. As Goldschmidt (I) remarks, this theory of the visible mechanism of sex distribution "is to-day so far proven that the demonstration stands on the level of an experimental proof in physics or chemistry." But why and how does this nuclear material determine sex? In other words, what is the nature of the process of differentiation into male and female which it sets in motion?

To begin with, we must give some account of the difference between the cells of male and female origin, an unlikeness capable of producing the two distinct types of gametes, not only in external appearance, but in chromosome makeup 
as well. It is due to the presence in the bodies of higher animals of a considerable number of glands, such as the thyroid in the throat and the suprarenals just over the kidneys. These pour secretions into the blood stream, determining its chemical quality and hence how it will influence the growth or, when grown, the stable structure of other organs and cells. They are called endocrine glands or organs, and their chemical contributions to the blood are known as hormones.

Sometimes those which do nothing but furnish these secretions are spoken of as "ductless glands," from their structure. The hormones (endocrine or internal secretions) do not come from the ductless glands alone-but the liver and other glands contribute hormones to the blood stream, in addition to their other functions. Some authorities think that " every cell in the body is an organ of internal secretion" (2), and that thus each influences all the others. The sex glands are especially important as endocrine organs; in fact the somatic cells are organized around the germ cells, as pointed out above. Hence the sex glands may be considered as the keys or central factors in the two chemical systems, the male and the female type.

These various hormones or chemical controllers in the blood interact in a nicely balanced chemical system. Taken as a whole this is often 
called the "secretory balance" or "internal secretory balance." This balance is literally the key to the sex differences we see, because it lies back of them; i.e., there are two general types of secretory balance, one for males and one for females. Not only are the secretions from the male and the female sex glands themselves quite unlike, but the whole chemical system, balance or "complex" involved is different. Because of this dual basis for metabolism or body chemistry, centring in the sex glands, no organ or cell in a male body can be exactly like the corresponding one in a female body.

In highly organized forms like the mammals (including man), sex is linked up with all the internal secretions, and hence is of the whole body. (3.) As Bell (2, p. 5) states it: "We must focus at one and the same time the two essential processes of life-the individual metabolism and the reproductive metabolism. They are interdependent. Indeed, the individual metabolism is the reproductive metabolism."

Here, then, is the reason men have larger, differently formed bodies than women-why they have heavier bones, tend to grow beards, and so on. The sex glands are only part of what we may call a well-organized chemical laboratory, delivering various products to the blood, but always in the same general proportions for a given sex. The ingredients which 
come from the sex glands are also qualitatively different, as has been repeatedly proved by injections and otherwise.

Each of these sex types, male and female, varies somewhat within itself, as is true of everything living. The two are not so far apart but that they may overlap occasionally in some details. For instance, some women are larger than are some men-have lower pitched voices, etc. The whole bodily metabolism, resting as it does upon a chemical complex, is obviously more like the male average in some women than it is in others, and vice versa. But the average physical make-up which we find associated with the male and female sex glands, respectively, is distinctive in each case, and a vast majority of individuals of each sex conform nearly enough to the average so that classification presents no difficulty.

The extreme as well as the average body types existing in the presence of the respective types of sex-glands are different. For example, we find an occasional hen with male spurs, comb or wattles, though she is a normal female in every other respect, and lays eggs. (4.) But we never find a functional female (which lays eggs) with all the typical characteristics of the male body. Body variation can go only so far in the presence of each type of primary sexuality (i.e., sexglands). 


\section{TABOO AND GENETICS}

The bodily peculiarities of each sex, as distinguished from the sex-glands or gonads themselves, are known as secondary sex characters. To put our statement in the paragraph above in another form, the primary and secondary sex do not always correspond in all details. We shall find as we proceed that our original tentative definition of sex as the ability to produce in the one case sperm, in the other eggs, is sometimes difficult to apply. What shall we say of a sterile individual, which produces neither? The problem is especially embarrassing when the primary and secondary sex do not correspond, as is sometimes the case.

Even in a fully grown animal, to remove or exchange the sex glands (by surgery) modifies the bodily type. One of the most familiar cases of removal is the gelding or desexed horse. His appearance and disposition are different from the stallion, especially if the operation takes place while he is very young. The reason he resembles a normal male in many respects is simply that sexuality in such highly-organized mammals is of the whole body, not of the sexglands or organs alone.

Suppose this horse was desexed at two years old. Nearly three years had elapsed since he was a fertilized egg. During the eleven months or so he spent within his mother, he developed a very complicated body. Beginning as a male, 
with a male-type metabolism (that is, as the result of a union between an $\mathrm{X}$ and a $\mathrm{Y}$ chromosome, not two X's), all his glands, as well as the body structures they control, developed in its presence. Not only the sex glands, but the liver, suprarenals, thyroid-the whole body in fact-became adjusted to the male type. He had long before birth what we call a male sex complex. Complex it is, but it is, nevertheless, easy enough to imagine its nature for illustrative purposes. It is simply all the endocrine or hormone-producing organs organized into a balanced chemical system-adjusted to each other.

When the horse had had this body and this gland system for nearly three years (eleven months within his mother's body and twentyfour outside), it had become pretty well organised and fixed. When a single chemical element (the hormones from the sex-glands) was withdrawn, the system (thus stereotyped in a developed body and glands) was modified but not entirely upset. The sex complex remained male in many respects. It had come to depend upon the other chemical plants, so to speak, quite as much as upon the sex glands. The later the castration is performed-the more fixed the body and gland type has become-the closer the horse will resemble a normal male. Much laboratory experimentation now goes to 
show that some accident while this horse was still a fertilized egg or a very small embryo might have upset this male type of body chemistry-perhaps even caused him to develop into a female instead, if it took place early enough. This is well illustrated by the so-called "Free-Martin" cattle, to be described later.

For a long time a controversy raged as to whether sex is determined at the time of fertilization, before or after. Biologists now generally prefer to say that a fertilized egg is "predisposed" to maleness or femaleness, instead of "determined." The word " determined " suggests finality, whereas the embryo appears to have in the beginning only a strong tendency or predisposition toward one sex type or the other. It is now quite commonly believed that this predisposition arises from the quantity rather than the quality or kind of factors in the chemical impetus in the nuclei of the conjugating gametes. A later chapter will be devoted to explaining the quantitative theory of sex.

Hence the modern theory of "sex determination " has become :

I. That the chemical factors which give rise to one sex or the other are present in the sperm and ovum before fertilization;

2. That a tendency or predisposition toward maleness or femaleness arises at 
the time of fertilization, depending upon which type of sperm unites with the uniform type of egg (in some species the sperm is uniform while the egg varies);

3. That this predisposition is:

a. Weaker at first, before it builds up much of a body and gland system to fix it ;

b. Increasingly stronger as the new body becomes organized and developed;

c. Liable to partial or complete upset in the very early stages ;

d. Probably quantitative-stronger in some cases than in others.

The new definition is, then, really a combination and amplification of the three older points of view.

The term "sex determination" does not mean to the biologist the changing or determining of the sex at will on the part of the experimenter. This might be done by what is known as " selective fertilization " artificially with only the kind of sperm ( $\mathrm{X}$ or $\mathrm{Y}$ as to chromosomes) which would produce the desired result. There is as yet no way to thus select the sperm of higher animals. It has been authoritatively claimed that feeding with certain chemicals, and other methods to be discussed later, has affected the sex of offspring. These experiments (and 
controversies) need not detain us, since they are not applicable to the human species.

Let us consider this fertilized egg-the contributions of the father and the mother. The total length of the spermatozoon is only about $\mathrm{I} / 300$ of an inch, and $4 / 5$ of this is the tail. This tail does not enter the egg, and has no other known function than that of a propeller. Its movement has been studied and found to be about I/8 of an inch per minute. Only the head and neck enter the egg. This head consists almost entirely of the nuclear material which is supposed to determine the characters of the future individual.

The ovum or egg contributed by the mother is much larger-nearly round in shape and about I/I20 of an inch in diameter. Besides its nucleus, it contains a considerable amount of what used to be considered as "stored nutritive material" for the early development of the individual.

In ancient times the female was quite commonly supposed to be a mere medium of development for the male seed. Thus the Laws of Manu stated that woman was the soil in which the male seed was planted. In the Greek Eumenides, Orestes' mother did not generate him, but only received and nursed the germ. These quaint ideas of course originated merely from observation of the fact that the woman 
carries the young until birth, and must not lead us to imagine that the ancients actually separated the germ and somatic cells in their thinking.

A modern version of this old belief was the idea advanced by Harvey that the ovum consisted of fluid in which the embryo appeared by spontaneous generation. Loeuwenhoek's development of the microscope in the I 7 th century led immediately to the discovery of the spermatozoon by one of his students. At the time, the "preformation theory" was probably the most widely accepted-i.e., that the adult form exists in miniature in the egg or germ, development being merely an unfolding of these preformed parts. With the discovery of the spermatozoon the preformationists were divided into two schools, one (the ovists) holding that the ovum was the container of the miniature individual, the other (animalculists) according this function to the spermatozoon. According to the ovists, the ovum needed merely the stimulation of the spermatozoon to cause its contained individual to undergo development, while the animaliculsts looked upon the spermatozoon as the essential embryo container, the ovum serving merely as a suitable food supply or growing place.

This nine-lived notion of male supremacy in inheritance was rather reinforced than removed 


\section{TABOO AND GENETICS}

by the breeding of domestic animals in the still more recent past. Attention has been focused on a few great males. For example, the breed of American trotting horses all goes back to one sire-Hambletonian Io. The great Orloff Stud Book, registering over a million individuals, is in the beginning founded on a single horse-a male. It is not strange that we still find among some breeders vestiges of the ancient belief that the male predominates in inheritance. A superior male can impress his characters in a single year upon roo times as many colts as a female of equal quality could produce in her lifetime. So slight an incident in his life is this reproductive process for each individual that he could if he devoted his life solely to reproduction stamp his characters upon a thousand times as many colts as could a female. Thus under artificial breeding conditions, the good males do have a tremendously disproportionate share in improving the whole breed of horses, though each single horse gets his qualities equally from his male and female parents.

Though Mendel knew an astonishing amount about inheritance a half-century ago, it is worth noting that the foundation upon which rests our present knowledge of sex has been discovered less than twenty years before-the reference is, of course, to the chromosomes as the carriers of inheritance. While from the standpoint of 


\section{4 TABOO AND GENETICS}

biology the opinions of two decades ago about sex literally belong to a different age, some of them have been so persistent in sociological thought and writings that they must be briefly reviewed in order that the reader may be on his guard against them. Books which still have a wide circulation deal with the sex problem in terms of a biology now no more tenable than the flatness of the earth.

On the one hand were the ancient traditions of male predominance in inheritance, reinforced by the peculiar emphasis which animal breeding places upon males. On the other hand, biologist like Andrew Wilson (5) had argued as early as the seventies of the past century for female predominance, from the general evidence of spiders, birds, etc. Lester F. Ward crystallized the arguments for this view in an article entitled "Our Better Halves" in The Formm in I888. This philosophy of sex, which he christened the "Gynæcocentric Theory," is best known as expanded into the fourteenth chapter of his "Pure Sociology," published fifteen years later. Its publication at this late date gave it an unfortunate vitality long after its main tenets had been disproved in the biological laboratory. Germ-cell and body-cell functions were not separated. Arguments from social structures, from cosmic, natural and human history, much of it deduced by analogy, were jumbled together 


\section{TABOO AND GENETICS}

in a fashion which seems amazing to us now, though common enough thirty years ago. It was not a wild hypothesis in I888, its real date, but its repeated republication (in the original and in the works of other writers who accepted it as authoritative) since I903 has done much to discredit sociology with biologists and, what is more serious, to muddle ideas about sex and society.

In I903, Weismann's theory of the continuity of the germplasm was ten years old. De Vries' experiments in variation and Mendel's rediscovered work on plant hybridization had hopelessly undermined the older notion that the evolution or progress of species has taken place through the inheritance of acquired characters -that is, that the individuals developed or adapted themselves to suit their surroundings and that these body-modifications were inherited by their offspring. As pointed out in Chapter I, biologists have accepted Weismann's theory of a continuous germplasm, and that this germplasm, not the body, is the carrier of inheritance. Nobody has so far produced evidence of any trace of any biological mechanism whereby development of part of the body-say the biceps of the brain-of the individual could possibly produce such a specific modification of the germplasm he carries as to result in the inheritance of a similar development by his offspring. 


\section{TABOO AND GENETICS}

Mendel's experiments had shown that the characters we inherit are units or combinations of units, very difficult to permanently change or modify. They combine with each other in all sorts of complicated ways. Sometimes one will "dominate" another, causing it to disappear for a generation or more; but it is not broken up. These characters have a remarkable way of becoming " segregated" once more-that is, of appearing intact later on.

While it follows from Weismann's theory that an adaptation acquired by an individual during his lifetime cannot be transmitted to his offspring, it remained for De Vries to show authoritatively that evolution can, and does, take place without this. Once this was established, biologists cheerfully abandoned the earlier notion. Lester Ward and the biologists of his day in general not only believed in the transmission of acquired characters, but they filled the obvious gaps which occurred in trying to apply this theory to the observed facts by placing a fantastic emphasis upon sexual selection. That is, much progress was accounted for through the selection by the females of the superior males. This, as a prime factor in evolution, has since been almost "wholly discredited" (Kellogg's phrase) by the careful experiments of Mayer, Soule, Douglass, Dürigen, Morgan and others. The belief in sexual 
selection involved a long string of corollaries, of which biology has about purged itself, but they hang on tenaciously in sociological and popular literature. For instance, Ward believed in the tendency of opposites to mate (tall men with short women, blonds with brunettes, etc.), although Karl Pearson had published a statistical refutation in his Grammar of Science, which had run through two editions when the Pure Sociology appeared. The greater variability of males than females, another gynæcocentric dogma had also been attacked by Pearson on statistical evidence in 1897 (in the well-known essay on Variation in Man and Woman, in Chances of Death) and has become increasingly unacceptable through the researches of Mrs. Hollingworth $(6,7,8)$. The idea of a vanished age of mother-rule in human society, so essential to the complete theory, has long since been modified by anthropologists.

De Vries' experiments showed that a moderately simple fact practically makes all these complicated theories unnecessary. No two living things are exactly alike-that is, all living matter is more or less variable. Some variations are more fortunate than others, and these variants are the ones which survivethe ones best adapted to their environment. Given this fact of the constant variation of living matter, natural selection (i.e., survival 
of the fittest and elimination of the unfit) is the mechanism of evolution or progress which best accounts for the observed facts. Such variation is called "chance variation," not because it takes place by "chance" in the properly accepted sense of the term, but because it is so tremendously varied-is evidently due to such complicated and little-understood circumstances - that it can best be studied mathematically, using statistical applications of the "theory of probabilities."

The fine-spun, elaborate theories about sex, so current twenty years ago, have fallen into almost complete desuetude among scientists. With the discovery of the place of the chromosomes in inheritance, biologists began to give their almost undivided attention to a rigid laboratory examination of the cell. This has included sex phenomena since McClung and Sutton pointed out the function of the sex chromosome in I902 and I903. Present-day "theories" are little more than working hypotheses, developed, not in a library or study, but with one eye glued to a high-power microscope.

Besides its faulty foundation as to facts, the old gynæcocentric theory involved a method of treatment by historical analogy which biologists have almost entirely discarded. Anyone inerested in the relative value of different kinds 


\section{TABOO AND GENETICS}

of biological data for social problems would do well to read the opening chapter of Prof. Morgan's " Critique of the Theory of Evolution" (9), for even a summary of which space is lacking here. College reference shelves are still stocked with books on sex sociology which are totally oblivious of present-day biology. For example, Mrs Gilman (Man-Made World), Mrs Hartley (Truth About Woman) and the Nearings (Woman and Social Progress) adhere to Ward's theory in substantially its primitive form, and not even sociologists like Professor Thomas (Sex and Society) have been able to entirely break away from it.

The old question of male and female predominance in inheritance has been to a considerable extent cleared up, to the discomfiture of both sides to the controversy. Most exhaustive experiments failed to trace any characters to any other part of either sperm or egg than the nucleus. Transmission of characteristics seemed to be absolutely equal by the two parents. The male nucleus enters the egg practically naked. Hence if the characters are transmitted equally, there is certainly ground for supposing that only the nucleus of the egg has such functions, and that the remainder merely provides material for early development. Yet this does not seem to be strictly true.

Parthenogenesis (development of eggs with- 


\section{TABOO AND GENETICS}

out agency of male sperm) proves that in many simple forms the female nucleus alone possesses all the essential determiners for a new individual. Boveri's classic experiment (Io) proved the same thing for the male nucleus. He removed the nuclei from sea-urchin eggs and replaced them with male nuclei. Normal individuals developed. To make things still more certain, he replaced the female nucleus with a male one from a different variety of sea-urchin. The resulting individual exhibited the characteristics of the male mucleus only-none of those of the species represented by the egg. Here, then, was inheritance definitely traced to the nucleus. If this nucleus is a male the characters are those of the male line; if a female those of the female line, and in sexual reproduction where the two are fused, half and half.

Yet the fact remained that all efforts to develop the spermatozoon alone (without the agency of any egg material at all) into an individual had signally failed. Conklin (II) had found out in I904 and I905 that the egg cytoplasm in Ascidians is not only composed of different materials, but that these give rise to definite structures in the embryo later on. So a good many biologists believed, and still believe (I2, I3, I4) that the egg is, before fertilization, a sort of "rough preformation of the future embryo" and that the Mendelian factors in 


\section{TABOO AND GENETICS}

the nuclei " only impress the individual (and variety) characters upon this rough block."

If we look at these views from one angle, the apparent conflict disappears, as Professor Conklin (I5) points out. We can still presume that all the factors of inheritance are carried in the nucleus. But instead of commencing the life history of the individual at fertilization, we must date it back, to the beginning of the development of the egg in the ovary. Whatever rude characters the egg possesses at the time of fertilization were developed under the influence of the nucleus, which in turn got them half and half from its male and female parents. These characters carried by the female across one generation are so rudimentary that they are completely covered up, in the developing embryo, by those of the new nucleus formed by the union of the sperm with the egg in fertilization.

In case fertilization does not take place, this rude beginning in the egg is lost. Since no characteristic sex is assumed until after fertilization, we may say that life begins as neuter in the individual, as it is presumed to have done in the world. It will occur to those inclined to speculation or philosophic analysis that by the word "neuter" we may mean any one or all of three things: (a) neither male nor female; (b) both male and female, as yet undifferentiated, 
or (c) potentially either male or female. Clearly, the above explanation assumes a certain germinal specialization of the female to reproduction, in addition to the body specialization for the intra-parental environment (in mammals).

A tremendous amount of laboratory experimentation upon animals has been done in late years to determine the nature of sex. For example, Goodale (r6) castrated a brown leghorn cockerel twenty-three days old and dropped pieces of the ovary of a female bird of the same brood and strain into the abdominal cavity. These adhered and built up circulatory systems, as an autopsy later showed. This cockerel, whose male sex glands had been exchanged for female ones, developed the female body, and colouration so completely that expert breeders of the strain pronounced it a female. He found that simply removing the female sex glands invariably led to the development of spurs and male plumage. But simple removal of the male sex glands did not alter plumage. To make sure, he replaced the male sex glands with female, and found that the former male developed female plumage.

This obviously signifies that in birds the female is an inhibited male. (4, p. 49.) Either sex when castrated has male feathers-the male has them either with or without testes, unless they are inhibited by the presence of (trans- 


\section{TABOO AND GENETICS}

planted) ovaries. It will be remembered that the sociological theory of sex held by Ward, Mrs. Hartley and a host of others was founded on the supposition that evolution or development of a species is chiefly due to selection by the females of the better males, a conclusion based almost entirely on bird evidence. Ward (I7) states that " the change or progress, as it may be called, has been wholly in the male, the female remaining unchanged"; also that "the male side of nature shot up and blossomed out in an unnatural, fantastic way . . ." Speaking of the highly-coloured males, especially among birds, the same writer states that "the normal colour (italics ours) is that of the young and the female, and the colour of the male is the result of his excessive variability." Goodale's results completely refute this idea, and should bury for ever the well-known sociological notion of " male afflorescence."

The general doctrine of a stable, "race-type" female and a highly variable male has been widely circulated. In tracing it back through voluminous literature, it appears to have been founded on an article published by W. I. Brooks in the Popular Science Monthly for June, I879, fourteen years before Weissmann's enunciation of the theory of continuity of the germ-plasm. Like Wallace, Brooks continued to study and experiment till the last, and finally withdrew 
from his earlier position on sexual selection. However, this has not prevented others from continuing to quote his discarded viewsinnocently, of course.

Havelock Ellis (I8) and G. Stanley Hall (I9) have applied the idea of a "race-type" female with peculiar insistence to the human race. Goodale has finally killed the bird evidence upon which earlier workers so largely founded this doctrine, by showing that the "race type" toward which birds tend unless inhibited by the female ovarian secretion is the male type, not the female. There is a great difference in the way the internal secretions act in birds and in man, as will be pointed out later. It is so important that such a major point as general variability must be supported and corroborated by mammalian evidence to prove anything positively for man. As already noted, the statistical studies of Pearson and Mrs. Hollingworth et al. have yielded uniformly negative results.

In the utilization of data gathered from nonhuman species, certain differences in the systems of internal secretion must be taken into account. Birds differ from the human species as to internal secretory action in two vital particulars: In the higher mammals, sex depends upon a "complex" of all the glands interacting, instead of upon the sex glands alone as in birds; (b) The male bird instead of the female is homo- 
gametic for sex-i.e., the sperm instead of the eggs is uniform as to the sex chromosome.

Insects are (in some cases at least) like birds as to the odd chromosone-the opposite of man. But as to secondary sex-characters they differ from both. These characters do not depend upon any condition of the sex organs, but are determined directly by the chemical factors which determine sex itself. (20.)

In crustacea, the male is an inhibited female (the exact opposite of birds), as shown by the experiments of Giard and Geoffrey Smith on crabs. A parasite, Sacculina neglecta, sometimes drives root-like growths into the spider crab, causing slow castration. The females thus desexed do not assume the male type of body, but castrated males vary so far toward the female type that some lay eggs ( 3 , p. I43; 20). It is the discovery of such distinctions which makes it necessary to re-examine all the older biological evidence on the sex problem, and to discard most of it as insufficiently exact.

The work of Steinach (12, pp. 225f.) on rats is another well-known example of changing sex characters by surgery. Steinach found that an ovary transplanted into a male body changed its characteristics and instincts into the female type. The growth of the male sex organs he found to be definitely inhibited by the ovaries. He went so far as to transplant the whole 
uterus and tube into the male body, where it developed normally. One of the most interesting of his results is the observation of how the instincts were changed along with the type of body. The feminized males behaved like normal females toward the other males and toward females. Likewise they were treated as normal females by the males.

It would be impossible to give here any just idea of the vast amount of rigid scientific experimentation which has been carried on in this field, or the certainty of many of the results. Sex is really known, about as well as anything can be known, to arise from the chemical causes discussed above. That is, the endocrine explanation is the correct one.

One of the most significant results of the transplantation experiments is the evidence that each individual carries the fundamental bases for both sexes. When Goodale changed a male bird into a female as to secondary characters and instincts by replacing one secretion with another, he was faced with the following problem : How can a single secretion be responsible for innumerable changes as to feather length, form and colouring, as to spurs, comb and almost an endless array of other details? To suppose that a secretion could be so complicated in its action as to determine each one of a thousand different items of structure, colour 


\section{TABOO AND GENETICS}

and behaviour would be preposterous. Besides, we know that some of these internal secretions are not excessively complicated-for instance adrenalin (the suprarenal secretion) can be compounded in the laboratory. We may say that it cannot possibly be that the ovarian or testicular secretion is composed of enough different chemical substances to produce each different effect.

There remains only the supposition that the female already possesses the genetic basis for becoming a male, and vice versa. This is in accord with the observed facts. In countless experiments it is shown that the transformed female becomes like the male of her own strain and brood-to state it simply, like the male she would have been if she had not been a female. If we think of this basis as single, then it must exhibit itself in one way in the presence of the male secretions, in another way under the influence of the female secretions. In this way a very simple chemical agent in the secretion might account for the whole difference-merely causing a genetic basis already present to express itself in the one or the other manner.

This may be illustrated by the familiar case of the crustacea Artemia salina and Artemia Milhausenii. These are so unlike that they were long supposed to be different species; but it was later discovered that the genetic basis is 
exactly the same. One lives in 4 to $8 \%$ salt water, the other in $25 \%$ or over. If, however, the fresh-water variety is put in the saltier water with the salt-water variety, all develop exactly alike, into the salt-water kind. Likewise, if the salt-water variety is developed in fresh water, it assumes all the characteristics of the fresh-water kind. Thus the addition or subtraction of a single chemical agent-common salt-makes all the difference.

If this basis for sex is single, it is represented by the male plumage in domestic birds, the secretions from the sex-glands acting as modifiers. But a great deal of evidence has been produced to show that the genetic basis, in man and some other forms at least, is double. That is, we must think of two genetic bases existing in each individual-each representing one of the two types of secondary sex characters. The primary sex (i.e., the sex glands) would then determine which is to express itself. In the domestic birds described above, the male type of body appears in the absence of the ovarian secretion, and the female type in its presence. In man and the more highly organized mammals, we must use "secretions" in the plural, since a number of them, from different glands, act together in a " complex." Goodale, experimenting with birds, was unable to definitely decide whether the basis for sex was single 
or double in that material, though he favoured the latter explanation.

Dr Bell, the English gynecologist, using human surgical cases as a basis, commits himself strongly to the dual basis. (2, p. I3.) "Every fertilized ovum," he says, " is potentially bisexual," but has "a predominating tendency ... toward masculinity or femininity." But "at the same time," he remarks, "it is equally obvious that latent traits of the opposite sex are always present." After discussing mental traits observed in each sex which normally belong to the other, he concludes as follows: "If further evidence of this bisexuality, which exists in everyone, were required, it is to be found in the embryological remains of the latent sex, which always exist in the genital ducts."

In some lower forms, dual sexuality is apparent until the animal is fairly well developed. In frogs, for example, the sex glands of both sexes contain eggs in early life, and it is not possible to tell them apart with certainty, until they are about four months old. (I2, p.I25.) Then the eggs gradually disappear in the male.

However, we need not depend upon nonmammalian evidence for either the secretory explanation or the dual basis. An ideal case would be to observe the effects of circulating the blood of one sex in a developing embryo of 
the other. This blood-transfusion occurs in nature in the "Free-Martin" cattle. (2I.)

Two embryos (twins) begin to develop in separate membranes or chorions. At an early stage in this development, however, the arteries and veins of the two become connected, so that the blood of each may circulate through the body of the other. "If both are males or both are females no harm results from this ...." since the chemical balance which determines the bodily form in each case is of the same type. But if one is a male and the other a female, the male secretory balance dominates the female in a very peculiar fashion. The female reproductive system is largely suppressed. She even develops certain male organs, and her general bodily appearance is so decidedly masculine that until Dr Lillie worked out the case she had always been supposed to be a non-functional male. She is sterile. The blood transfusion not only alters the sex-type of her body, but it actually modifies the sex glands themselves, so that the ovary resembles a testicle, though dissection proves the contrary.

Why does not the female become a true, functional male? Perhaps she does in some cases. Such a one would not be investigated, since there would be no visible peculiarity. In all the cases examined, the embryo had begun its female development and specialization under 
the influence of a predisposition of the female type in the fertilized egg, before the transfusion began. There is no absolutely convincing mammalian evidence of the complete upset of this predisposition, so all one can say is that it is theoretically possible. Cases of partial reversal, sometimes called "intersexes," are common enough. In birds and insects, where the material is less expensive and experimentation simpler, males have been produced from female-predisposed fertilized eggs and vice versa, as we shall see in the next chapter.

Dr Bell (2, pp. I33f.) points out that the so-called human " hermaphrodites" are simply partial reversals of the sex type from that originally fixed in the fertilized egg. As has been remarked earlier in these pages, there is rarely if ever true hermaphroditism in higher animals-i.e., cases of two functional sexes in the same individual. In fact, the pathological cases in the human species called by that name are probably not capable of reproduction at all.*

* Note on human hermaphroditism: This subject has been treated in a considerable medical literature. See, for example, Alienist and Neurologist for August, I9I 6 , and New York Medical Journal for Oct. 23, I9I5. It has been claimed that both human and higher mammalian " hermaphrodites" have actually functioned for both sexes. Obviously, absolute certainty about cause and effect in such cases, where human beings are concerned, is next to impossible, because of lack of scientific, laboratory control. If a case of complete functional hermaphroditism in the human species could be established beyond question, it would indicate that the male secretory balance in man does not inhibit the female organs to 
Like the Free-Martin cattle, some accident has resulted in a mixture of male and female characteristics. This accident occurs after a certain amount of embryonic development has taken place under the influence of the original predisposition of the fertilized egg. The delicate secretory balance, so complex in man, is upset. With partially developed organs of one type and with a blood-chemistry of the opposite one, some curious results follow, as the illustrative plates in Dr Bell's book show.

It should be remembered that sex in higher mammals is of the whole body, and depends upon all the secretions. Hence an accident to one of the other glands may upset the balance as well as one to the sex glands themselves. For example, I $5 \%$ of Neugebauer's (22) cases of female tubular partial hermaphroditism had abnormal growths in the suprarenals.

Thus in the human species, it is possible for one type of sex glands to exist in the opposite

the same extent that it apparently does in the Free-Martin cattle. If established, the idea of "male dominance" in the human species would be undermined in a new place. Such cases, if they occur at all, are exceedingly rare, but are of theoretical interest. We must not rush to conclusions, as the earlier sociologists used to do. Such a case would require careful analysis. Its very uniqueness would suggest that it may not be due to the ordinary causes of hermaphroditism, but might arise from some obscure and unusual cause such as the fusion of two embryos at a very early stage. The biochemistry involved is so intricate and so little understood that any deduction from the known facts would be purely speculative. 
type of body, as we saw it to be in cattlethough it apparently could not occur unless compensated for in some way by the other secretions. This is a very great departure from birds, rats and guinea pigs, whose bodies change over their sex type when the gonads are transplanted. Birds take on the male appearance when the sex glands are removed (or retain it, if they are males). This is not true of man. The chemical life processes of the two sexes after puberty in the human species are quite characteristic. The male and female types are both very different from the infantile. When it becomes necessary to desex men, the resulting condition is infantile, not female. (23.)

The desexed man is of course the eunuch of ancient literature. If desexed near maturity, he might look like a normal man in many respects; but if the operation were performed before puberty, his development is simply arrested and remains infantile-incomplete. Only in 1878 was the practice of desexing boys to get the famous adult male soprano voices for the Sistine Choir discontinued.

Removal of the ovaries in women likewise produces an. infantile condition, which is pronounced only in case the operation takes place very young. (24.) From his clinical experience, $\operatorname{Dr}$ Bell (2, p. I60) concludes that no very definite modifications can be produced in an 
adult woman by withdrawal of the ovarian secretion alone. "There must be," he says, "some gross change in those parts of the endocritic system, especially apart from the genital glands, which normally produce masculinitya potentiality that appears to be concentrated in the suprarenals, the pituitary and probably in the pineal."

What, then, do we mean by "male" and "female" in man? Take Dr Russell Andrews' patient: photographs (2, plate opposite p. 243) show a rounded bodily outline, hairless face, well-developed mammæ-the female sex charateristics in every respect which the ordinary person could detect. Yet an operation proved that the sex glands themselves were male.

Presumably extreme cases like the above are rare. Obviously operations cannot be performed on all those with female-type bodies who do not bear children, to determine the primary sex, and conversely with men. This does, however, point the obvious question : Are not some we classify as men more male or masculine than others-some we classify as women more feminine than others? Bearing in mind the fact that the genetic basis for both sexes exists in each individual, are not some women more masculine than others, some men more feminine than others? However much we 


\section{TABOO AND GENETICS}

may object to stating it just that way, the biological fact remains thus. The Greeks called these intermediate types urnings-modern biology knows them as "intersexes."

Only within the past few years have the general phenomena of intersexuality been cleared up to any considerable extent-naturally on the basis of the secretory explanation of sex. This secretory or endocrine idea has also given us an entirely new view of sex differences. These are best discussed as functional rather than as structural. To correlate this material, we must next give a rude sketch of the quantitative theory of sex.

\section{BIBLIOGRAPHY FOR CHAPTER II}

I. Goldschmidt, R. Intersexuality and the Endocrine Aspect of Sex. Endocrinology, Vol. I, p. 434, I9I7. 2. Bell, Dr Blair. The Sex Complex. London, Igr6, p. 98 .

3. Paton, D. Noêl. Regulators of Metabolism. London, I9I3, p. I46.

4. Goodale, H. D. Gonadectomy . . Carnegie Pub. 243, I9I6, pp. 43f.

5. Wilson, Andrew. Polity of a Pond (essay). Humboldt Lib. of Sc., No. 88-reprint, dated I888

6. Hollingworth, L. S. Variability as Related to Sex Differences in Achievement. Am. Jour. of Sociol., XIX., I9I4, pp. 510-530.

7. Lowie, R. H. \& Hollingworth, L. S. Science and Feminism. Sci. Mthly., Sept., Igr6, pp. 277-284.

8. Montague, Helen \& Hollingworth, L. S. Comparative Variability of the Sexes at Birth. Am. J. of Sociol. $\mathrm{XX}, 335-70$. I9I5. 
9. Morgan, T. H. A Critique of the Theory of Evolution. N. Y., I916, pp. I-27.

Io. Loeb, Jacques. Artificial Parthenogenesis and Fertilization. Chicago, 1913, pp. 3, 5 I f., 240f., 303. II. Conklin, E. G. Organ-Forming Substances in the Eggs of Ascidians. U. of Pa. Contrib. from the Zool. Lab. Vol. I2. I905, pp. 205-230.

I2. Loeb, J. The Organism as a Whole. N. Y., Igr6, pp. I38f., I5I-2.

I3. Guyer, M. F. Being Well-Born. Indianapolis, I9I6, p. 5 I.

I4. Tower, W. L. (et. al.). Heredity and Eugenics. Chicago, I9I2, pp. I64, 254-5.

I5. Conklin, E. G. Share of Egg and Sperm in Heredity. Proc. Nat. Acad. of Sc., Feb., I9I7.

16. Goodale, H. D. A Feminized Cockerel. Jour. Exp. Zool. Vol. 20, pp. 42I-8.

I7. Ward, Lester F. Pure Sociology. N. Y., I903, pp. $322 f$.

I8. Ellis, Havelock. Man and Woman, 4th Ed. London, I904. Ch. XVI.

I9. Hall, G. Stanley. Adolescence. N. Y., I907. Vol. II, pp. $56 \mathrm{I}-2$.

20. Morgan, T. H. Heredity and Sex. N. Y., Igr3, pp. $\mathrm{I}_{55} \mathrm{f}$.

2I. Lillie, F. R. Theory of the Free Martin. Science, n. s., Vol. XIIII, pp. 6ri-I3.

22. Neugebauer, F. L. Hermaphrodismus, Leipzig, Igo8. 23. Vincent, S. Internal Secretions and the Ductless Glands. London, I9I2, p. 69.

24. Marshall, F. H. Physiology of Reproduction. London, I9IO, P. 3I4. 


\section{CHAPTER III}

SEX AND SEX DIFFERENCES AS QUANTITATIVE

Intersexes in moths ; Bird intersexes; Higher metabolism of males; Quantitative difference between sex factors; Old ideas of intersexuality; Modern surgery and human intersexes; Quantitative theory a Mendelian explanation; Peculiar complication in the case of man; Chenical life cycles of the sexes; Functionalreproductive period and the sex problem; Relative significance of physiological sex differences.

Crossing European and Japanese gypsy moths, Goldschmidt ( $I, 2,3,4)$ noticed that the sex types secured were not pure-i.e., that certain crosses produced females which bore a distinctly greater resemblance to the male type than others, and vice versa. One of these hybrids of " intersexes," as he calls them, would always possess some female and some male sexual characters. He found that he could separate the males and females, respectively, into seven distinct grades with respect to their modification toward the opposite-sex type, and could produce any one of these grades at will by breeding.

For example, the seven grades of females were roughly as follows: (I) Pure females; 
(2) Females with feathered antennæ like males and producing fewer than the normal number of eggs; (3) Appearance of the brown (male) patches on the white female wings; ripe eggs in abdomen, but only hairs in the egg-sponge laid; instincts still female; (4) Instincts less female; whole sections of wings with male colouration, interspersed with cuneiform female sectors ; abdomen smaller, males less attracted ; reproduction impossible; (5) Male colouration over almost the entire wing; abdomen almost male, with few ripe eggs ; instincts intermediate between male and female; (6) Like males, but with rudimentary ovaries and show female traits in some other organs; (7) Males with a few traces of female origin, notably wing-shape.

The males showed the same graded approach to the female type. Their instincts likewise became more and more female as the type was modified in that direction. That is, a moth would be $12 \%$ or $35 \%$ female, and so on.

Goldschmidt watched the crosses which produced seven different grades of maleness in his females. The moth material, like the birds and mammals, suggested a dual basis for sex in each individual. The grades of maleness and femaleness made it seem probable that the factor which determines sex must be stronger in some instances than in others, i.e., that the difference between two of these grades of female 
is originally quantitative, not qualitative-in amount rather than in kind.

Mating European moths with European, or Japanese with Japanese, produced pure, uniform sex-types, male and female. But a cross of European with Japanese strains resulted in intersexes. Goldschmidt concluded that (I) all individuals carried the genetic basis for both sexes; and (2) that these basic factors were two chemicals of enzyme nature. One of these he called Andrase, enzyme producing maleness, the other Gynase, enzyme producing femaleness. Further, (3) since each chemical sex determiner is present in both individuals in every cross, there must be two chemical "doses" of maleness and two of femaleness struggling for mastery in each fertilized egg. (4) If the total dose of maleness exceeds the total dose of femaleness, the sex will be male, and vice versa. (5) These quantities get fixed by natural selection in a single race which always lives in the same environment, i.e., the doses of maleness and femaleness in a given sex always bear practically the same relation to each other. Hence the types are fixed and uniform. (6) But different races are likely to have a different strength of chemical sex-doses, so that when they are crossed, the ratios of maleness to femaleness are upset. Often they are almost exactly equal, which produces a type half male and half 
female-or $2 / 3$, or $I / 3$, etc. The proof of this theory is that it solved the problems. Goldschmidt was able to work out the strengths of the doses of each sex in his various individuals, and thereby to predict the exact grade of intersexuality which would result from a given cross.

Riddle's work on pigeons $(5,6)$ brings us much nearer to man, and suggests the results noted by both Goldschmidt and Lillie. As in the Free-Martin cattle, there is an apparent reversal of the sex predisposition of the fertilized egg. As in the gypsy moths, different grades of intersexes were observed. In the pigeons, it was found that more yolk material tended to produce a larger proportion of females. The most minute quantitative measurements were made of this factor, to eliminate any possibility of error.

The chromosome mechanisms practically force us to suppose that about half the eggs are originally predisposed to maleness, half to femaleness. A pigeon's clutch normally consists of two eggs, one with a large yolk and one with a small yolk. But the half-and-half numerical relation of males to females varies considerably-i.e., not all the large-yolked eggs produce females or all the small-yolked ones males.

Wild pigeons begin the season by throwing a predominance of males, and the first eggs of 
the clutches also tend to produce males all along. In both cases, the male-producing eggs were found to be the ones with the smaller yolks. Family crosses also produce small yolks, which hatch out nearly all males. Some pairs of birds, however, have nearly all female offspring. Riddle investigated a large number of these cases and found the amount of yolk material to be large. In other words, there seems to be a definite relation between the amount of yolk and sex.

A great number of clever experiments were carried out to find out if eggs originally predisposed to one sex were actually used to produce the other. Selective fertilization with different kinds of sperm was impossible, since in these birds there is only one type of spermtwo of eggs-as to the sex chromosome. For instance, by overworking females at egg-production, the same birds which had been producing more males than females were made to reverse that relation.

One of the interesting results of the experiments was the production of a number of intersexual types of various grades. This was easily verifiable by colour and other characteristics. To make sure that the instincts were correspondingly modified, behaviour was registered on moving-picture films. Where the first egg of a clutch (the one with a small, normally 
male-producing yolk) produces a female, she is usually found to be more masculine than her sister from the second egg with the larger yolk. This is true both as to appearance and as to behaviour. Some of these were quite nearly males in appearance and behaviour, though they laid eggs.

Testicular and ovarian extracts were injected. The more feminine birds were often killed by the testicular extract, the more masculine by the ovarian extract. Finally, to make assurance doubly sure, some females which should theoretically have been the most feminine were dissected and shown to be so. That is, out-crosses which produced a predominance of females in the fall were mated with females which had been overworked at egg production until they threw nearly all females. Dissecting the females thus produced, they were shown to have right ovaries, which means double femaleness, since normally the pigeon is functional only in the left ovary, like other birds. The right one usually degenerates before or at hatching and is wholly absent in the week-old squab.

In pigeons, Riddle thinks the " developmental energy" of the eggs is in an inverse ratio to their size. The last and largest eggs of the season develop least and produce most females. The second egg of a clutch is larger than the first, but develops less and the bird produced 
is shorter-lived. Overworking and other conditions tending to produce large eggs and females also throw white mutants and show other signs of weakness. Old females lay larger eggs than do young ones. These eggs produce more females. They store more material, have a lower metabolism and less oxidizing capacity than do the earlier male-producing eggs.

It would be unsafe to draw specific conclusions about mammals from these bird and insect experiments. Both the secretory action and the chromosome mechanisms are different. The quantitative nature of sex, and also the existence of intersexual types, between males and females, would seem to be general phenomena, requiring rather slight corroboration from the mammals themselves. We have such mammalian cases as the Free-Martin cattle, and some convincing evidence of intersexuality in the human species itself, which will be reviewed presently.

The notion of more " developmental energy" or a higher metabolism in males is borne out in the human species. Benedict and Emmes (7) have shown by very careful measurements that the basal metabolism of men is about $6 \%$ higher than that of women. Riddle cites the work of Thury and Russell on cattle to show that a higher water value (as he found in the pigeon eggs), associated with increased metabolism, helps to produce males. 
In males, the secretion of the sex glands alone seems to be of particular importance, again suggesting this idea of "strength" which comes up over and over again. Removal of these glands modifies the male body much more profoundly than it does the female. (8.) It is quite generally supposed that the action of this one secretion may have much to do with the superior size and vigour of males. For example, Paton says (9): "The evidence thus seems conclusive that in the male the gonad, by producing an internal secretion, exercises a direct and specific influence upon the whole soma, increasing the activity of growth, moulding the whole course of development, and so modifying the metabolism of nerve and muscle that the whole character of the animal is altered." It used to be said that the male was more " katabolic," the female more "anabolic." These expressions are objectionable, inasmuch as they hint that in a mature organism, with metabolism rather stable, tearing down, or katabolism, could go on faster than building up, or anabolism, or that one of two phases of the same process might go on faster than the other. It seems safer to say merely that a lower metabolism in the female is accompanied by a tendency to store materials.

A long time will doubtless be required to work out the details of differences in metabolism in 


\section{TABOO AND GENETICS}

the two sexes. Some of the main facts are known, however, and the general effects of the two diverse chemical systems upon the life cycles of the sexes are quite obvious. What we call the "quantitative theory of sex" has, besides a place in exact science, an interesting relation to the history of biological thought, especially as applied to society. It is thus in order to state as clearly as possible what it now is; then, so that no one may confuse it with what it is not, to run over some of the old ideas which resemble it.

Experiments with transplanted sex glands, with sex-gland extracts (testicular and ovarian) and the observation of infusions of a male-type blood-stream into a female body, as occurs in nature in some cattle and in the so-called human " hermaphrodites," indicate a gross chemical difference between the respective determiners for femaleness and for maleness. So the chemicals involved, though not yet isolated, must be presumed to be qualitatively different, since they produce such different results.

But such experiments also indicate that both determiners must be present in some proportions in every individual of either sex. The basis for both sexes being present, the one which shall predominate or be expressed in the individual must depend upon the quantitative relation between the determiners which come 
together at fertilization. The quantitative theory merely means that this predominance of one factor or the other (maleness or femaleness - Gynase or Andrase) is more pronounced in some cases than in others.

In brief, then, the quantitative theory of sex is merely the most reasonable explanation of the known fact that intersexes exist-that is, females with some male characteristics, or with all their characters more like the female type than the average, and vice versa. Laboratory biology has established the phenomena of intersexuality beyond question, and the word " intersex" has become a scientific term. But the fact that this word and the idea it represents are new to exact science does not mean that it is new in the world.

Intersexes in the human species-not only the extreme pathological cases represented by the so-called " hermaphrodites," but also merely masculine women and effeminate men-have been the subject of serious remarks as well as literary gibes from the earliest times The Greeks called these people urnings. Schopenhauer was interested in the vast ancient literature and philosophy on this subject. The Igth century produced a copious psychological treatment of warped or reversed sexual impulses by such men as Moll, Krafft-Ebing and Havelock Ellis. Otto Weiniger (Io) collected a mass 


\section{TABOO AND GENETICS}

of this philosophy, literature, psychology, folklore and gossip, tied it together with such biological facts as were then known (IgOI) and wove around it a theory of sex attraction.* The same material was popularized by Leland (II), Carpenter (I2) and W. L. George (I3) to support quite different views.

George's statement that "there are no men and .... no women; there are only sexual majorities" (p. 6I, op. cit.) has been widely quoted. The feminists, he adds, "base themselves on Weininger's theory, according to which the male principle may be found in woman, and the female principle in man.' Unfortunately, George does not make clear what he means by " principle," so his theory, if he has one, is impossible to appraise in biological terms. From the embryonic idea expressed above, he deduces a very positive social

* Note: Weiniger thought he could pick, merely by observing physical type, people who would be sexually attracted to each other. There is much ground for scepticism about this. To begin with, the biological experiments indicate that intersexes are peculiarly likely to appear where two or more races are mixed. So far, there is no exact knowledge about the amount or kind of sex difference in each race. As Bateson remarks (Biol. Fact \& the Struct. of Society, p. I3), one unversed in the breeds even of poultry would experience great difficulty and make many mistakes in sorting a miscellaneous group of cocks and hens into pairs according to breed. If this is true in dealing with pure breeds, " in man, as individuals pure-bred in any respect are very rare, the operation would be far more difficult." In the human species sexual attraction also obviously depends upon many factors which are not purely biological; it is rather a complicated sentiment than an instinct. 
philosophy of sex. The feminists, he says, " recognize no masculine or feminine 'spheres," and ... propose to identify absolutely the conditions of the sexes." So, while George seems to think much more highly of women than does Weininger, their philosophies come together, for quite different reasons, on the practical procedure of disregarding reproduction and letting the race go hang (Io, p. 345). Weininger seems to recognize the dual basis for sex ; George evidently does not quite follow him. Both entirely misconceived the real issues involved, as well as the kind of evidence required to settle them, as we shall see later in discussing adaptation and specialization.

Dr Blair Bell (I4, I5) has collected a mass of evidence on intersexes in the human species. This includes his own surgical and other cases, as well as many treated by his colleagues, and a very considerable review of the medical literature. He not only believes in degrees of femininity in women, but has worked out classifications which he claims to have found of great practical value in surgery (I4, pp. I66-7). As noted above, Riddle discovered that his more feminine female pigeons were often killed by a dose of testicular extract which was practically harmless to a partially masculinized female. Sex in the human species being a matter of all the glands organized into a complex, 


\section{TABOO AND GENETICS}

the quantitative "strength" of that complex would be useful to know before removing any one secretion from it. Dr Bell states that the oöphorectomy operation (removal of ovaries) may be performed upon a masculine type of woman with " little disturbance of the metabolism..." But he thinks that the degree of masculinity should always be carefully observed before undertaking such operations, which in some cases have most undesirable effects.

At one end of the scale, this surgeon places the typically feminine woman in all her characteristics-with well-formed breasts, menstruating freely and feminine in instincts-he says " mind." The intermediate grades consist, he says, of women whose metabolism leans toward the masculine type. Some have sexual desires but no maternal impulse. Others desire maternity but take no interest in sex activity, or positively shun it. The physical manifestations of masculine glandular activity take the form of pitch of voice, skin texture, shape and weight of bones, etc. Some of the inter-grades are a little hard to define-the human species is such an inextricable mixture of races, etc.; but Dr Bell does not hesitate to describe the characteristically masculine woman of the extreme type, who "shuns both sexual relations and maternity ... (She) is on the fringe of femin- 
inity. These women are usually flat-breasted and plain. Even though they menstruate, their metabolism is often for the most part masculine in character: indications of this are seen in the bones which are heavy, in the skin which is coarse, and in the aggressive character of the mind. ... If a woman have well-developed genitalia, and secondary characteristics, she usually is normal in her instincts. A feebly menstruating woman with flat breasts and coarse skin cannot be expected to have strong reproductive instincts, since she is largely masculine in type..."

The glandular and quantitative explanation of sex, instead of being abstruse and complicated, brings the subject in line with the known facts about inheritance generally. The dual basis for femaleness and maleness in each individual simply means that both factors are present, but that only one expresses itself fully. The presence of such a dual basis is proved by the fact that in castration and transplantation experiments both are exhibited by the same individual in a single lifetime. In the case of the Free-Martin cattle, even the female sexglands are modified toward the male type to such an extent that they were long mistaken for testes. The same applies to some glands found in human "hermaphrodites," as Dr Bell's plates show. 
The peculiar complication of the chemical complex determining sex in these mammalian forms, involving all the glands and hence the entire body, makes it problematical whether a complete (functional) reversal is possible, at least after any development whatever of the embryo has taken place. On the other hand, the fact that such complete transformations have not so far been observed by no means proves their non-existence. Their being functional, and hence to all external appearances normal, would cause such animals to escape observation.

Latent traits of the opposite sex of course immediately suggest recessive or unexpressed characters in the well-known Mendelian inheritance phenomena. In the bird-castration cases, we saw that to remove the inhibiting sex glands caused previously latent characters to act like dominant or expressed ones. The case of horns in sheep, investigated by Professor Wood (I6), is so similar that it seems worth summarizing, by way of illustration.

Both sexes in Dorset sheep have well-developed horns; in the Suffolk breed both sexes are hornless. If the breeds are crossed, all the rams in the first (hybrid) generation have horns and all the ewes are hornless. If these hybrids are mated, the resulting male offspring averages three horned to one hornless; but the females 
are the reverse of this ratio-one horned to three hornless. This is an example of Mendel's principle of segregation-factors may be mixed in breeding, but they do not lose their identity, and hence tend to be sorted out or segregated again in succeeding generations.

In the horned Dorsets, we must suppose that both males and females carry a dual factor for horns-technically, are homozygous for horns. The hornless Suffolks, on the contrary, are homozygous for absence of horns. Thus the dual factor in the zygotes or fertilized eggs at the basis of the first filial (hybrid) generation consits of a single factor for horns and a single factor for their absence. If we represent horns by $H$ and absence of horns by $A$, Dorsets have a factor $H H$, Suffolks $A A$ and the hybrids $H A$.

All the males in this generation have horns, which means that a single " dose" of the factor $H$ will produce horns in a male, or that they are dominant in males. But a single dose will not produce horns in a female-that is, horns are recessive in females-the factor is present but unexpressed.

Mating two $H A$ hybrids, the $H$ and $A$ of course split apart in the formation of the gametes, as the $H H$ and $A A$ did in the previous generation; so that we get an equal number of single $H$ and $A$ factors. In reuniting in fertilized eggs, the chance is just half and half that 
an $H$ will unite with another $H$ or with an $A-$ that an $A$ will unite with an $H$ or another $A$. Thus we have two chances of getting $H A$ to each chance of getting either $A A$ or $H H$. Half the zygotes will be $H A$, one-fourth $H H$ and one-fourth $A A$.

If we consider four average males, one will have two $A$ 's (absence of the factor for horns) and will thus be hornless. One will have two $H$ 's, or the double factor for horns, and hence will exhibit horns-as will also the two $H A$ 's since a single dose of horns expresses them in a male. So we have the three-to-one Mendelian ratio.

But four females with exactly the same factors will express them as follows: The one $H H$ (double factor for horns) proves sufficient to express horns, even in a female. The $A A$, lacking the factor entirely, cannot have horns. Nor will the two $H A$ females have horns, a single dose being insufficient to express them in a female. Again we get our three-to-one Mendelian ratio, but this time it is three hornless to one horned.

Especially Goldschmidt's carefully graded experiments point to a similar difference in the strength of the dose or doses of the sex factors. Instead of the two doses of horns required to express them in the presence of the female secretory balance in Professor Wood's 
sheep, Goldschmidt found it took six doses of maleness to completely express it on a female basis in his moths. But even with three doses, the female was incapable of reproduction. A single dose in excess of the ordinary combination to produce normal females modified the type of body, also reducing the number of eggs.

In the case of the horns, only two types were possible, absence or presence of the character. Likewise there are only two types of primary sex, i.e., of sex glands proper. But seven different types or grades of body for each sex were found to exhibit themselves in the moths. In more complicated bodies, we should of course expect many more, and where many races (instead of two) are mixed, as in man, a classification merely on the basis of physical characteristics would be much more complicated. Indeed, we may well be sceptical as to the possibilities of cataloguing differences of the sort between men and women by body type alone.

In society, however, we are much more interested in the mental than the purely physical qualities of the two types of bodies, especially since the use of machines has so largely replaced brute strength with skill. Most employments do not even require a muscular skill beyond that possessed by ordinary individuals of both sexes. 
Even this ignores the primary consideration in the sex problem in society, the first of the following two parts into which the whole problem may be divided: (I) How to guarantee the survival of the group through reproduction of a sufficient number of capable individuals; and (2) How to make the most economical use of the remaining energies, first in winning nutrition and protection from the environment, second in pursuing the distinctly human values over and above survival. The sex problem as a whole is concerned with adjusting two different general types of individuals, male and female, to the complicated business of such group life or society. The differences between these two sex-types being fundamentally functional, the best way to get at them is to trace the respective and unlike life cycles.

We have already shown in rude outline how a difference (apparently chemical) between two fertilized eggs starts them along two different lines of development in the embryonic stage. One develops the characteristic male primary and secondary sex characters, the other the female. Throughout the embryonic or intramaternal stage this differentiation goes on, becoming more and more fixed as it expresses itself in physical structures. Childhood is only a continuation of this development-physically separate from the mother after the period of 
lactation. Until puberty, when sex ceases to be merely potential and becomes functional (about I2-I4 in girls and I4-I6 in boys), the differences in metabolism are not very marked. Neither are they in old age, after sex has ceased to be functional. It is during the period when sex is functional (about 35 years in women and considerably longer in men) that the gross physiological differences manifest themselves.

Before puberty in both sexes, calcium or lime salts are retained in the tissues and go to build up the bony skeleton. (A mere sketch of calcium metabolism is all that can be given here - for details consult such works as I5 and I7 in bibliography; summary in I4; pp. 34f. \& I6If.) Note that puberty comes earlier in girls than in boys, and that the skeleton therefore remains lighter. During the reproductive period in women these salts are heavily drawn upon for the use of the reproductive system. The male reproductive system draws upon them as well, though the drain is very slight as compared to that in women. In old age these salts produce senility through deposit in the tissues, especially in the arteries.

At the pubertal age in girls begins the phenomenon known as menstruation, in which there is a large excretion of calcium salts. In pregnancy these are needed for building the skeleton of the fœtus, and at delivery go to the 


\section{TABOO AND GENETICS}

breasts to assist in lactation. Bell states that there is a noticeable connection between early menstruation and short stature, and vice versa. What is commonly known as menstruation lasts only a few days, and is merely the critical period in a monthly cycle or periodicity which goes with the female sex specialization. This period involves the gradual preparation of the uterus or womb for a guest, together with the maturing of the ova. Then the Graafian follicles containing the ova break and these latter enter the uterus for fertilization.

If fertilization takes place, the fertilized egg buries itself in the wall and development of the embryo proceeds. Menstruation stops, the calcium salts being required for the growing embryo. There is likely to be no menstruation for a considerable time after delivery if the child is nursed, as is normal. This gives the uterus time for devolution to the normal, before a surplus of calcium salts sets the periodicity going again. If the egg which passes from the ovary to the uterus is not fertilized, it is excreted, the uterus goes through another monthly cycle of preparation for the period of intra-maternal environment, and so on indefinitely until the climacteric.

This climacteric or decay of sexuality is a rather critical time, especially in women. It marks the period at which the metabolism can 
no longer support the strain of reproduction. A surplus of calcium brings on senility, as noted above. Withdrawal of the interests which centre in sex, together with the marked accompanying physical changes, involves a shift of mental attitude which is also frequently serious. A British coroner stated in the British Medical Journal in I900 (Vol. 2, p. 792) that a majority of 200 cases of female suicide occurred at this period, while in the case of younger women suicide is peculiarly likely to occur during menstruation. Krugelstein and Lombroso, respectively, remark the same tendencies. (I8.)

It is a matter of almost everyday observation that men and women in the neighbourhood of fifty suddenly find themselves disoriented in the world. Tolstoi, for example, who had written passionately of passion in his earlier years, suddenly awoke, according to his " Confessions," from what seemed to him afterward to have been a bad dream. In this case, the result was a new version of religion as a new anchorage for the man's life. It may be pacifism, prohibition, philanthropy, or any one of a very large number of different interestsbut there must usually be something to furnish zest to a life which has ceased to be a sufficient excuse for itself.

If freed from worry about economic realities, it is not infrequently possible for the first time 
for these people to " balance" their lives-to find in abstraction a rounded perfection for which earlier in life we seek in vain as strugglers in a world of change. Thus old people are often highly conservative, i.e., impatient of change in their social environment, involving re-orientation; they wish the rules of the game let alone, so they can pursue the new realities they have created for themselves.

Socially, the old are of course a very important factor since a changed metabolism sets them somewhat outside the passionate interests which drive people forward, often in wrong directions, in the prime of life. Hence in a sense the old can judge calmly, as outsiders. Like youth before it has yet come in contact with complicated reality, they often see men and women as "each chasing his separate phantom."

While such conservatism, in so far as it is judicial, is of value to society, looking at it from the viewpoint of biology we see also some bad features. Senex, the old man, often says to younger people, "These things you pursue are valueless-I too have sought them, later abandoned the search and now see my folly; " not realizing that if his blood were to resume its former chemical character he would return to the quest.

Elderly people, then, biological neuters, come especially within the problem of the economical 
use of the social as distinguished from the biological capacities of the race. They affect the sex problem proper, which applies to a younger age-class, only through their opinions. Some of these opinions are hangovers from the time in their own lives when they had stronger sexual interests, and some are peculiar to people of their readjusted glandular activity. Their reproductive contribution to society has been made.

Pre-pubertal childhood and youth, on the contrary, has its biological contributions to society still before it. The glandular activity of boys and girls is perhaps not so unlike as to justify society in giving them a different kind of education and preparation for group life. The excuse for two sorts of training is that the two sexes will not do the same work after puberty. Hence the question of youthful training is sociological almost entirely-not biological-or rather, it rests upon the biology, not of childhood but of the reproductive period, which society anticipates.

Instead of scattering attention over the whole history of the universe, then, or even over the general field of biology, in dealing with sex as a social problem, the emphasis must be upon the human life cycle during the functionalreproductive period. Other biological data than that which concerns this period is merely intro- 
ductory or explanatory. The extent to which the sociological problem involved is linked up with general biological considerations like natural selection, adaptation and specialization will be summarized in a separate chapter.

Earlier female maturity and puberty, as well as lighter structure, have already been accounted for by the metabolism, especially of the calcium salts. These have also been shown to be the key fact in the monthly periodicity of the mammalian female. Nearly all of the anatomical and physiological sex differences catalogued by such pioneer workers as Ellis, Ploss, Thomas and Bucura are simply what we should expect from the less active and in some ways peculiar metabolism of woman.

Among such differences are the size and shape of bones and other body structures, the more plentiful hæmoglobin in male blood during the reproductive period, and such blood peculiarities as the production of more carbonic acid or the higher specific gravity in the male. The greater percentage of fat as compared with muscle in women (I9), if it is generally true, is what we should expect from a lower metabolism and a tendency to store materials. The long list of diseases which are more or less sex-limited (20; I4, pp. I6of. ; I8) are largely endocrine. Even those which do not primarily concern the internal secretory system would be expected to 
work somewhat differently in the presence of unlike blood streams. As to the greater average weight of the male brain, this is true of the whole body. Brain weight, either absolute or relative to body weight, is not positively known to be in any way correlated (in normal people) with mental capacity.

A library might be stocked with the vast literature devoted to summarizing and cataloguing sex differences; and most of it would be useless from the standpoint of sociology. Unaccompanied by the criticisms a biologist would have to make on the method of their ascertainment and validity, not to mention their significance, such lists can easily do-and probably have done-more harm than good. One simple and reasonable criterion would reduce this catalogue to fairly modest proportions, so far as social science is concerned: Which ones have an obvious or even probable social significance? Over and above that, while such contrasts may be of speculative interest, they lead imaginative people to argue from them by analogy and thus cloud the real issues.

What are the outstandingly significant sex differences which application of the above criterion leaves? (I) A less active and more uneven metabolism of woman; (2) Associated with this, less physical strength on the average -hence an inferior adaptability to some kinds 


\section{TABOO AND GENETICS}

of work, resulting in a narrower range of choice of occupation, disadvantageous in competitive society; (3) But the one fundamental difference, to which all the others are as nothing, is the specialization of the mammalian female body and metabolism to furnish the intra-maternal environment (approximately nine months in the human species) for the early development of the young and lactation for some months afterward.

This last may be said to include the former two, which were arbitrarily placed first because they are always in evidence, whether reproduction is undertaken or not. This takes us out of cell and endocrine biology and into the general problem in group adjustment to environment which that specialization entails.

\section{BIBLIOGRAPHY FOR CHAPTER III}

I. Goldschmidt, R. Experimental Intersexuality and the Sex Problem. Amer. Naturalist, I9r6. Vol. 50, pp. 705 f.

2. Goldschmidt, R. Preliminary Report on Further Experiments in Inheritance and Determination of Sex. Proc. Nat. Acad. Sc., rgr6. Vol. II, No. I, pp. 53 f.

3. Goldschmidt, R. A Case of Facultative Parthenogenesis. Biol. Bulletin, rgr7. Vol. XXXII, No. r, p. 38 .

4. Goldschmidt, R. Intersexuality and the Endocrine Aspect of Sex. Endocrinology, Vol. I, p. 434. IgI\%. Fine summary of the work done on moths, birds and various forms by many biologists. 
5. Riddle, Dr Oscar. Quantitative Basis of Sex as indicated by the Sex-Behaviour of Ioves from a Sex-Controlled Series. Science, n.s., Vol. 39, p. 440, I9I4.

6. Riddle, Dr Oscar. Sex Control and Known Correlations in Pegeons. Amer. Nat. Vol. L, pp. 385-4Io. 7. Benedict, F. G. \& Enmmes, L. E. A Comparison of the Basal Metabolism of Men and Women. Jour. Biol. Chem. Vol. 20. No. 3. I9I4.

8. Schäfer, Sir E. A. Endocrine Glands and Internal Secretions. Stanford University, I9I4, p. 9I.

9. Paton, D. Noël. Regulators of Metabolism. London, I9I3, p. I46.

Io. Weininger, Otto. Sex and Character. London \& N. Y., I906. Eng. trans. of Geschlecht u. Charakter, Vienna \& Leipzig, I90 I \& I903.

II. Leland, C. G. The Alternate Sex. I-ondon, I904. I2. Carpenter, Edw. Love's Coming of Age. London, I906.

I3. George, W. L. The Intelligence of Woman, Boston, IgI6.

I4. Bell, Dr Blair. The Sex Complex, London, I9ı6.

I5. Bell, Dr. Blair. Gynæcology. I.ondon, I9I9.

I6. Bateson, W. Mendel's Principles of Heredity. I9og, pp. I69-70.

I7. Marshall, F. H. A Physiology of Reproduction. London, I9Io.

I8. Ellis, Havelock. Man and Woman. Igo4 ed., pp. $284 \mathrm{f}$.

I9. Thomas, W. I. Sex and Society. I907, p. I9.

20. Schäfer, Sir Edw. An Introduction to the Study of Internal Secretions. London, I9I6, pp. Io6f. 


\section{CHAPTER IV}

\section{SEX SPECIALIZATION AND GROUP SURVIVAL}

Adaptation and specialization; Reproduction a group not an individual problem; Conflict between specialization and adaptation; Intelligence makes for economy in adjustment to environment; Reproduction, not production, the chief factor in the sex problem.

From the facts briefly stated in the preceding chapters it is quite evident that the general superiority of man over woman or vice versa cannot be proven by biology. Such an idea arises from a careless and unscientific use of language. Superiority is a term which, when used to express the rather exact ideas of biology, is employed in a carefully limited and specific, not in a general, sense. That is, superiority, even if an apparently general idea like survival value is referred to, always implies a given, understood environment where such is not specifically mentioned. Wolves, for example, might be found to possess superior chances for survival over foxes, beaver or partridges in a given environment. A biologist would probably use more exact and less ambiguous terms to express such a fact, and say that wolves were 
the best adapted to the given surroundings. If all these animals continued to live side by side in the given environment, they could be compared only as to specific details-size, strength, cunning, fleetness in running, swimming or flying, concealment from enemies, etc. Then the biologist would probably make his meaning perfectly clear by stating that one is specialized in one direction or another.

Especially is general superiority a vague idea when the things compared are different but mutually necessary or complementary. If their functions overlap to some extent (i. e., if certain acts can be performed by either), we may say that one is better adapted to a certain activity than the other. Thus it may be that women are generally better adapted to caring for young children than are men, or that men are on the whole better adapted to riveting boiler plates, erecting skyscrapers, or sailing ships. Where their activities do not overlap at all, even the word adaptation hardly applies. For example, women are not better " adapted " to furnishing the intra-maternal environment for the young, since men are not adapted to it at all. It is a case of female specialization.

Men being neither specialized nor adapted, to any extent whatever, to this particular activity, any attempt at comparison is obviously fruitless, since one term is always zero. This 
specialization, absolutely necessary to the survival of human groups, is either present or it is absent in a given individual. Any attempt to formulate a general proposition about superiority either attaches purely arbitrary values to different kinds of activity or is absurd from the standpoint of the most elementary logic.

From the standpoint of biology, reproduction is not an individual but a group problem, however many problems of detail it may give rise to in individual lives. Sex involves the division of the reproductive process, without the exercise of which any human group would perish very shortly, into two complementary, mutually necessary but unequal parts. (This statement applies only to the reproductive process, as obviously the male and female gametes contribute equally to the formation of the new individual). Neither part (the male or the female) of this process is more necessary than the other, both being absolutely necessary. But the female specialization for furnishing the intra-maternal environment makes her share more burdensome.

Biologically considered, not even two individuals (male and female), together with their offspring, can be more than an arbitrary " unit " as concerns sex, since inbreeding eventually impoverishes the stock. Hence outcrosses are necessary. To intelligibly consider the sex 
problem in the human species, then, we must always predicate a considerable group of people, with such organization and division of activities as to guarantee that all the processes necessary to survival will be carried on. Sex is a group problem. Considering the mutual interdependence and the diversity of activities in human society, to make the generalization that one sex is superior to the other is on a par with saying that roots and branches are superior to trunks and leaves. It is sheer foolishness. Yet oceans of ink have flowed in attempts to establish one or the other of two equally absurd propositions.

Since the specialization to furnish the intramaternal environment for the young makes the female part of the reproductive process essentially and unavoidably more burdensome than the male, it results that an economical division of the extra-reproductive activities of any group must throw an unequal share upon the males. This specialization to carry the young during the embryonic period is thus at the base of the division of labour between the sexes. It is the chief factor involved in the problems of sex, and gives rise, directly or indirectly, to most of the others.

But the sex problem as a whole is one of adaptation as well as of specialization. An incident of the female specialization is a type 


\section{TABOO AND GENETICS}

of body on the average smaller, weaker and less well adapted to some other activities than is the male body, even when reproduction is not undertaken. A great complication is added by the fact that some women, and also some men, are better adapted than others to nonreproductive activities. This is another way of saying that the type of body associated with either type of sex glands varies a good deal, for reasons and in respects already pointed out.

The most important fact about this reproductive specialization is that beyond fertilization it is exclusive in the female. Since the males cannot furnish the intraparental environment for the young, the entire burden must fall on half the group. If this aggregation is to even hold its own numerically, its women must have, on an average, two children each, plus about one more for unavoidable waste--death in infancy or childhood, sterility, obvious unfitness for reproduction, etc., i.e., three in all. If one woman has less than her three children, then another must have more than three, or the group number will decrease. Group survival is the fundamental postulate in a problem of this kind.

The above figure is for civilized society. In primitive groups, the terrific wastage makes a much higher birth-rate necessary, several times as high in many cases. If we suppose such a 


\section{TABOO AND GENETICS}

group, where child mortality, lack of sanitation, etc., necessitates an average of eight children per woman (instead of three), the biological origin of the division of labour between the sexes is much more clearly seen than it is in civilized societies.

If men are better hunters or fighters than women, the latter could nevertheless hunt and fight-it is a question of superior or inferior adaptation to particular activities. But it is more than that. Only the women are biologically specialized to the chief reproductive burden (intra-parental environment and lactation). If half the women should withdraw from childbearing, the remainder would be obliged to average sixteen apiece. But even this is not all. Unfortunately, the half of the women who would be found best adapted to hunting and fighting would be the more vigorous half. The new generation would thus be born from the leftovers, and would be poor quality. Such a division of labour within a group would be fatally foolish and entirely uncalled for-since there are plenty of men adapted to hunting and fighting, but entirely unspecialized to child-bearing and nursing.

Group survival being the fundamental thing, the group is obliged to develop a division of labour which directs the activities of the individuals composing it to providing for its 
necessities, regardless of any interference with their own desires. That is, if group survival requires that woman use her specialization to child-bearing instead of any adaptation she may possess in other directions, one of two things inevitably result: (I) Either the group finds or evolves some social control machinery which meets the necessity, or (2) it must give way to some other group which can do so. In either case, the result is a division of labour, which we see more clearly in primitive peoples. The less efficient group is not necessarily exterminated, but if it loses out in the competition until some other group is able to conquer it and impose its division of labour the result is of course the extinction of the conquered group as an integral part of society. This is simply natural selection working on groups. Natural selection works chiefly in this manner on the human species, because that species lives in groups. Such group control of the component individuals as has been described has led to a division of labour. between the sexes in every primitive society. All this means is that the group adopting such a division has greater survival value, and hence is more likely to be represented in later ages.

It must not be supposed that such systems of control were always logically thought out or deliberately planned. Even animals which live in herds or colonies have divisions of labour 
Through an infinite slaughter of the least fit, such groups arrive at some kind of instinctive adjustment to produce and protect the young. The crudest human intelligence must have eliminated much of the waste involved, by comprehending obvious cause-and-effect relations which animals have to arrive at through trial and error methods.

For example, an intelligence capable of employing artificial weapons is also able to see that the wielder of these for group defence cannot be encumbered with baggage or children when the group is in movement. Hence women became the burden bearers, and took care of the children, even after the nursing period. War parties could not generally be mixed, for the obvious reasons that such women as did not have young children would be pregnant a good deal of the time, or likely to become so. Moreover, a hunter and fighter must not have his courage, ferocity and physical initiative undermined by unsuitable employments and associations.

In a semi-settled group, the hunter and warrior cannot be relied upon to keep hearthfires burning or tend crops, even though he may occasionally have time for such activities. These duties are therefore relegated to the women, whose child-bearing functions impose upon them a more sedentary existence. Women must reproduce practically up to their full capacity to 


\section{TABOO AND GENETICS}

fill up the gaps made by war, accident and disease as well as death from old age. To this biological service which they alone can perform are added those which lie nearest it and interfere least with carrying it out.

We must therefore keep in view all the activities of any group in which the sex problem is being studied. There is a certain tendency to disregard the female specialization to childbearing, and to regard the sex question as one merely of adaptation to extra-biological services. In every group which has survived, some machinery-a "crust of custom," reinforced by more arbitrary laws or regulationshas sought to guarantee reproduction by keeping women out of lines of endeavour which might endanger that fundamental group necessity. Primitive societies which got stabilized within a given territory and found their birth-rate dangerously high could always keep it down by exposing or destroying some of the unfit children, or a certain per cent of the female children, or both.

In primitive groups, the individual was practically nil. But modern civilized society is able to survive without the rigid control of individual activities which the old economy entailed. Man comes to choose more and more for himself individually instead of for the group, uniformity weakens and individualism 
becomes more pronounced. As control of environment becomes more complete and easy, natural selection grows harder to detect. We turn our interests and activities toward the search for what we want and take survival largely for granted-something the savage cannot do. Natural selection becomes unreal to us, because the things we do to survive are so intricately mixed up with those we do for other reasons. Natural selection in gregarious animals operates upon groups rather than upon individuals. Arrangement of these groups is often very intricate. Some have territorial boundaries and some have not. Often they overlap, identical individuals belonging to several. Hence it is not strange that natural selection phenomena often escape attention.

But this must not lead us to suppose that natural selection is wholly inoperative in civilized society. We see some nations outbreeding others, or dominating them through superior organization. Within nations, some racial and religious groups outbreed others and thus gradually supplant them-for the future is to those who furnish its populations. 


\section{CHAPTER V}

RACIAL DEGENERATION AND THE NECESSITY FOR RATIONALIZATION OF THE MORES

Racial decay in modern society ; Purely " moral " control dysgenic in civilized society; New machinery for social control; Mistaken notion that reproduction is an individual problem; Economic and other factors in the group problem of reproduction.

From the discussion in the preceding chapter, it becomes apparent that for the half of the female element in a savage society possessing the most vigor and initiative to turn away from reproduction would in the long run be fatal to the group. Yet this is what occurs in large measure in modern civilized society. Reproduction is a biological function. It is non-competitive, as far as the individual is concerned, and offers no material rewards. The breakdown of the group's control over the detailed conduct and behaviour of its members is accompanied by an increasing stress upon material rewards to individuals. So with growing individualism, in the half of the race which can both bear children and compete in the social activities offering rewards, i.e., the women 
who are specialized to the former and adapted to the latter, there is a growing tendency among the most successful, individualized strains, to choose the social and eschew the biological functions.

Racial degeneration is the result. Recorded history is one succession of barbarous races, under strong, primitive breeding conditions, swamping their more civilized, individualized neighbours, adopting the dysgenic ways of civilization and then being swamped in their turn by barbarians. This is especially pronounced in our own times because popularized biological and medical knowledge makes it possible for a tremendous class of the most successful and enlightened to avoid reproduction without foregoing sex activity.

In primitive groups, a "moral" control which kept all women at reproduction was neither eugenic nor dysgenic unless accompanied by systematic destruction of the least fit children. By " moral " control is meant the use of taboo, prejudice, religious abhorrence for certain acts and the like. The carefully nurtured moral ideas about sex and reproduction simply represent the system of coercion which groups have found most effective in enforcing the division of reproductive and other activities among the individual members. When this social machinery grew up, to regulate sexual activity was in 
general to regulate reproduction. The natural sex desire proved sufficiently powerful and general to still seek its object, even with the group handicaps and regulations imposed to meet the reproductive necessity. But contraceptive knowledge, etc., has now become so general that to regulate sex activity is no longer to regulate reproduction. The taboo or " moral" method of regulation has become peculiarly degenerating to race quality, because the most intelligent, rationalized individuals are least affected by it.

There is no turning back to control by ignorance. Even theoretically, the only way to stop such a disastrous selection of the unfit would be to rationalize reproduction-so that nobody shall reproduce the species through sheer ignorance of how to evade or avoid it. This done, some type of social control must be found which will enable civilized societies to breed from their best instead of their worst stock. Under the old scheme, already half broken down, natural selection favours primitive rather than civilized societies through decreased birth-rates and survival of the unfit in the latter. Even this is true only where the savage groups are not interfered with by the civilized, a condition rapidly disappearing through modern occidental imperialism and the inoculation of primitive peoples with "civilized" diseases 
such as syphilis, rum-drinking and rampant individualism.

To continually encourage the racially most desirable women to disregard their sexual specialization and exploit their social-competitive adaptation must obviously destroy the group which pursues such a policy. The only way to make such a course democratic is to carefully instruct all women, rich and poor, wise and ignorant, in the methods of avoiding reproduction and to inject the virus of individualism in all alike. Then the group can get its population supply only by a new system of control. To remove any economic handicaps to child-bearing is certainly not out of harmony with our ideas of justice.

In removing the economic handicaps at present connected with the reproductive function in women, care must also be taken that the very measures which insure this do not themselves become dysgenic influences. Such schemes as maternity insurance, pensions for mothers, and most of the propositions along this line, may offer an inducement to women of the poorer classes to assume the burdens connected with their specialization for child-bearing. But their more fortunate sisters, who find themselves so well adapted to modern conditions that they are even moderately successful in the competition for material rewards, will hardly find 


\section{TABOO AND GENETICS}

recompense thus for turning from their social to their biological functions. To these highly individualized modern women must be presented more cogent reasons for taking upon themselves the burden of reproducing the group.

It is obvious that from just this energetic female stock we should obtain a large part of the next generation if we are at all concerned over the welfare of the group and its chances of survival. One suggestion is that we may be able to turn their very individualism to account and use it as a potent factor in the social control of their reproductive activities. If we can demonstrate on the basis of sound biological data that the bearing of children is necessary for the full and complete development of the individual woman, physically and mentally, we shall have gone a long way toward securing voluntary motherhood. Only such argument will induce the highly individualized, who may also be the most vital, woman to turn of her own accord from competitive social activities to the performance of the biological function for which she is specialized. This is especially true, as has been intimated above, since contraceptive knowledge now permits the exercise of sexual functions without the natural consequences, and the avoidance of motherhood no longer involves the denial of expression to the sexual urge. 
Even if we are able to utilize this method of control, it will not obtain the requisite number of offspring to maintain the eugenic quality of the group, since the bearing of one or two children would be all that individual development would require. If the group must have on the average three children from each of its women in order to replace itself, the larger part of the reproductive activities will still be confined to the more ignorant, or if they also make use of contraceptive knowledge, the group will simply die out from the effects of its own democratic enlightenment. Thus it becomes apparent that we must find some more potent force than this narrow form of self-interest to accomplish the social purposes of reproduction. When reproduction is generally understood to be as thoroughly a matter of group survival as for example the defensive side in a war of extermination, the same sentiment of group loyalty which now takes such forms as patriotism can be appealed to. If the human race is unsocial it will perish anyway. If it has not become unsocial-and it does not display any such tendency, but only the use of such impulses in mistaken directions -then a group necessity like reproduction can be met. Whatever is required of the individual will become " moral " and "patriotic"-i.e., it will be wreathed in the imperishable sentiments which group themselves around socially neces- 
sary and hence socially approved acts everywhere and always.

In whatever races finally survive, the women of good stock as well as poor-perhaps eventually the good even more than the poor-will reproduce themselves. Because of our ideals of individual liberty, this may not be achieved by taboo, ignorance or conscription for motherhood. But when it is found to be the personal interest to bear children, both as a means of complete physical and mental development and as a way of winning social approval and esteem, it will become as imperative for woman to fulfil the biological function to which she is specialized as it was under the old system of moral and taboo control. The increasing emphasis on the necessity of motherhood for the maintenance of a normal, health personality, and the growing tendency to look upon this function as the greatest service which woman can render to society, are manifest signs that this time is approaching. There is little doubt that woman will be as amenable to these newer and more rationalized mores as human nature has always been to the irrationally formed customs and traditions of the past.

To ignore the female specialization involved in furnishing the intramaternal environment for three children, on an average, to the group, is simply foolish. If undertaken at maturity 
-say from twenty-two to twenty-five years of age-and a two-year interval left between the three in the interest of both mother and children, it puts woman in an entirely different relation toward extra-reproductive activities than man. It does imply a division of labour.

In general, it would seem socially expedient to encourage each woman to have her own three children, instead of shifting the burden upon the shoulders of some other. If such activities of nursing and caring for the very young can be pooled, so much the better. Doubtless some women who find them distasteful would be much more useful to society at other work. But let us not disregard fundamentals. It is obviously advantageous for children of normal, able parents to be cared for in the home environment. In a biologically healthy society the presumption must be that the average woman has some three children of her own. Since this obviously includes nurses and governesses, we see at once the futility of the oft-proposed class solution of hiring single women to care for the children of the fortunate. If such a servant is undesirable, she is not hired; if normal, in a biologically healthy society she would have her own children.

The female handicap incident to reproduction may be illustrated by the case of Hambletonian Io mentioned in Chapter II. We saw that a 


\section{TABOO AND GENETICS}

female could not have borne the hundredth part of his colts. This simply means that the effort or individual cost of impressing his characters upon the new generation is less than one onehundredth that required of a female.

Among domestic animals this is made use of to multiply the better males to the exclusion of the others, a valuable biological expedient which we are denied in human groups because it would upset all our social institutions. So we do the next best thing and make the males do more than half in the extra-biological activities of society, since they are by their structure prevented from having an equal share in the reproductive burden. This is an absolutely necessary equation, and there will always be some sort of division of labour on the basis of it.

Since reproduction is a group, not an individual, necessity, whatever economic burden it entails must eventually be assumed by society and divided up among the individuals, like the cost of war or any other group activity. Ideally, then, from the standpoint of democracy, every individual, male or female, should bear his share as a matter of course. This attitude toward reproduction, as an individual duty but a group economic burden, would lead to the solution of most of the problems involved. Negative eugenics should be an immediate assumption-if the state must pay for offspring, the quality will 
immediately begin to be considered. A poor race-contribution, not worth paying for, would certainly be prevented as far as possible.

Some well-meaning radical writers mistakenly suppose that the emancipation of women means the withdrawal by the group of any interest in, or any attempt to regulate, such things as the hours and conditions of female labour. That would simply imply that the group takes no interest in reproduction-in its own survival. For if the group does not make some equation for the greater burden of reproduction upon women, the inevitable result will be that that particular service will not be rendered by those most desirable to be preserved.

Given the fundamental assumption that the group is to survive--to be perpetuated by the one possible means-if it withdraws all solicitude about the handicap this entails to women as a whole, introducing a spirit of laissez-faire competition between men and women, the women with sense enough to see the point will not encumber themselves with children. For each one of these who has no children, some other woman must have six instead of three. And some people encourage this in the name of democracy!

The most involved problems must inevitably centre around the women who, to quote Mrs. Hollingworth, "vary from the mode," but are 
yet functional for sex. Some have no sex desires at all, some no craving for or attachment to children, some neither of these. It is a question still to be solved whether some of them ought, in the interest of the race, to be encouraged to reproduce themselves. In less individualized primitive society, seclusion, taboo and ignorance coerced them into reproduction. Any type of control involving the inculcation of " moral" ideas is open to the objection that it may work on those who should not reproduce themselves as well as those who should.

In a sense, this problem will tend to solve itself. With the substitution of the more rationalized standards of self-interest and group loyalty for the irrational taboo control of reproductive activities, there will be as much freedom for women to choose whether they will accept maternity as there is now, in the period of transition from the old standards to the new. The chief difference will be that many of the artificial forces which are acting as barriers to motherhood at the present time-as for example the economic handicap involved-will be removed, and woman's choice will therefore be more entirely in harmony with her native instinctive tendencies. Thus those women endowed with the most impelling desire for children will, as a rule, have the largest number. In all probability their offspring will inherit 


\section{Io6 TABOO AND GENETICS}

the same strong parental instinct. The stocks more poorly endowed with this impulse will tend to die out by the very lack of any tendency to self-perpetuation. It is only logical to conclude, therefore, that as we set up the new forces of social control outlined in this chapter, we are at the same time providing more scope for natural selection, and that the problem of aberrant types consequently becomes only a transitory one. 


\section{PART II.}

\section{THE INSTITUTIONALIZED SEX TABOO}

BY

IVA LOWTHER PETERS, PH.D. 



\section{CHAPTER I}

\section{THE PRIMITIVE ATTITUDE TOWARD SEX AND WOMANHOOD}

Primitive social control; Its rigidity; Its necessity; Universality of this control in the form of taboos; Connection between the universal attitude of primitive peoples towards woman as shown in the Institutionalized Sex Taboo and the magic-religious belief in Mana; Relation of Mana to Taboo; Discussion of Sympathetic Magic and the associated idea of danger from contact; Difficulties in the way of an inclusive definition of Taboo; Its dual nature; Comparison of concepts of Crawley, Frazer, Marett and others; Conclusion that Taboo is Negative Mana ; Contribution of modern psychology to the study of Taboo ; Freud's analogy between the dualistic attitude toward the tabooed object and the ambivalence of the emotions; The understanding of this dualism together with the primitive belief in Mana and Sympathetic Magic explains much in the attitude of man toward woman; The vast amount of evidence in the taboos of many peoples of dualism in the attitude toward woman. Possible physiological explanation of this dualistic attitude of man toward woman found in a period before self-control had in some measure replaced social control, in the reaction of weakness and disgust following sex festivals.

A study of the elaborate, standardized, and authoritative systems of social control found 
among all primitive peoples gives a vivid impression of the difficulty of the task of compelling man to die to himself, that is, to become a socius. The rigors and rituals of initiation ceremonies at adolescence impressed the duties of sociality at that impressionable period. The individual who refused to bow his head to the social yoke became a vagabond, an outcast, an excommunicate. In view of the fierceness of the struggle for food and the attitude toward the stranger among all primitives, the outcast's life chances were unenviable. It was preferable to adapt one's self to the social order. "Bad" traits were the more easily suppressed in return for the re-enforcement of power which was the striking feature of group life; power over enemies, power over nature, and a re-enforcement of the emotional life of the individual which became the basis on which were built up the magico-religious ceremonies of institutionalized religion.

It is the purpose of this study to consider a phase of social life in which there can be traced a persistence into modern times of a primitive form of control which in a pre-rational stage of group life made possible the comparatively harmonious interplay of antagonistic forces. This form of control is called Taboo. A student of the phenomenon, a recognized authority on its ethnological interpretation, says of it: "To 


\section{TABOO AND GENETICS}

illustrate the continuity of culture and the identity of the elementary human ideas in all ages, it is sufficient to point to the ease with which the Polynesian word tabu has passed into modern language." (I : p. I6.)

We shall attempt to show that at least one form of taboo, the Institutionalized Sex Taboo, is co-extensive with human social experience, and exists to-day at the base of family life, the socialized form of sex relationship. The family as a social institution has been scarcely touched until a very recent historical period by the rationalizing process that has affected religious and political institutions. Economic changes resultant upon the introduction of an industrial era which showed the importance of women in diverse social relations were causes of this new effort at adaptation to changing conditions. It became apparent that taboos in the form of customs, ceremonials, beliefs, and conventions, all electrically charged with emotional content, have guarded the life of woman from change, and with her the functions peculiar to family life. There has doubtless been present in some of these taboos " a good hard common-sense element." But there are also irrational elements whose persistence has resulted in hardship, blind cruelty, and over-standardization.

In order to comprehend the attitude of early man toward sex and womanhood, and to 
understand the system of taboo control which grew out of this attitude, it is only reasonable to suppose that the prehistoric races, like the uncivilized peoples of the present time, were inclined to explain all phenomena as the result of the action of spiritistic forces partaking of both a magical and religious nature. This supernatural principle which the primitive mind conceived as an all-pervading, universal essence, is most widely known as mana, although it has been discussed under other names.*

Certain persons, animals and objects $\dagger$ are often held to be imbued to an unusual degree with this mana, and hence are to be regarded as holy and held in awe. Inasmuch as man may wish to use this power for his own purposes, a ceremonial cult would naturally grow up by which this would become possible. Otherwise, to come in contact with these objects directly or indirectly, besides profaning their sanctity

*The Australians call it Arunkulta, the Iroquis Indians Orenda and other North American tribes Wakonda, the Melanesians Mana.

$\nmid \operatorname{Dr}$ F. B. Jevons (2) says: "These things ... are alike taboo: the dead body; the now-born child; blood and the shedder of blood ; the divine being as well as the criminal; the sick, outcasts, and foreigners; animals as well as men ; women especially, the married woman as well as the sacred virgin; food, clothes, vessels, property, house, bed, canoes, the threshing floor, the winnowing fan, a name, a word, a day; all are or may be taboo because dangerous. This short list does not contain one-hundredth part of the things which are supposed to be dangerous; but even if it were filled out and made tolerably complete, it would, by itself, fail to give any idea of the actual extent and importance of the institution of taboo." 


\section{TABOO AND GENETICS}

would be exceedingly dangerous for the transgressor, because of this same power of transmission of a dread and little understood force. Therefore, all such persons, animals or objects are taboo and must be avoided. Under these circumstances it can be seen that taboos are unanalyzed, unrationalized "Don'ts," connected with the use and wont which have crystallized around the wish of man to manipulate the mysterious and often desirable features of his environment, notably those connected with possession, food, and sex.

The idea of the transmission of mana through contact is concomitant with the notion of sympathetic magic, defined as the belief that the qualities of one thing can be mysteriously transferred to another. The most familiar illustration is that of the hunter who will not eat the heart of the deer he has killed lest he become timid like that animal, while to eat the heart of a lion would be to gain all the fierce courage of that beast.* This belief becomes so elaborated that the qualities of one object are finally thought to be transferred to another which has never come into direct contact with the first, the transition being accomplished through the agency of a third object which has been in contact with both the others and thus

*E. B. Tylor (3) has called attention to the belief that the qualities of the eaten pass into the eater as an explanation of the food taboos and prejudices of savage peoples. 
acts as the conducting medium through which the qualities of one pass into the other.

Just as the holy thing, which is to be feared as the seat of a mystic, supernatural force, is to be avoided lest harm befall from contact with it, or lest it be defiled by human touch and its divine essence be affected, so the unclean thing is also made taboo lest it infect man with its own evil nature. Even as the savage will not have his idol polluted by contact with his own personality, however indirect, so he would himself avoid pollution in similar fashion by shunning that which is unclean. Here also the avoidance of the tabooed person or thing is based on the principle of sympathetic magic understood as a method of transference of qualities, and on belief in the possibility of infection by contact.

The dual nature of taboo as the avoidance of both the sacred and the unclean is noted by authorities on the subject who differ in other respects as to the definition of taboo, such as in the relation of taboo to the magical ceremonies by which man undertook to mould his environment to his wishes. Whether the tabooed object be regarded in one light or the other, the breaking of taboo is associated with dread of the unknown-besides the fear of infection with the qualities of the tabooed object according to the laws of sympathetic magic. There is 


\section{TABOO AND GENETICS}

also the fear of the mysterious and supernatural, whether conceived as the mana force or as a principle of " bad magic."

Dr. J. G. Frazer has collected into the many volumes of "The Golden Bough" a mass of evidence concerning the taboos of primitive society. On the basis of his definition of magic as " a misapplication of the ideas of association by similarity and contiguity," Dr. Frazer divided magic into "positive magic," or charms, and "negative magic," or taboo. "Positive magic says, "Do this in order that so and so may happen.' Negative magic or taboo says "Do not do this lest so and so should happen.' "' (4: p. III, v. I.)

But Dr. Frazer's conclusion, which he himself considered only tentative, was not long left unassailed. Prof. R. R. Marett in his essay "Is Taboo a Negative Magic?" (5) called attention to the very evident fact that Dr. Frazer's definition would not cover the characteristics of some of the best known taboos, the food taboos of Prof. Tylor to which we have previously alluded in this study, as a consequence of which "the flesh of timid animals is avoided by warriors, but they love the meat of tigers, boars, and stags, for their courage and speed." (3: p. I3I.) Are not these food taboos rather, Dr. Marett asks, a " misapplication of the ideas of association by similarity and contiguity" 
amounting to the sympathetic taboos so carefully described by such writers on Magic as MM. Hubert and Mauss of L'Année Sociologique? Still another kind of taboos mentioned by Dr. Frazer but amplified by $\mathrm{Mr}$. Crawley in "The Mystic Rose," the taboos on knots at childbirth, marriage, and death, are much better described by the term " sympathetic taboo." Moreover, if taboo were a form of magic as defined by Dr. Frazer, it would be a somewhat definite and measurable quantity; whereas the distinguishing characteristic of taboo everywhere is the "infinite plus of awfulness" always accompanying its violation. As Dr. Marett observes, there may be certain definite results, such as prescribed punishment for violations against which a legal code is in process of growth. There may be also social " growlings," showing the opposition of public opinion to which the savage is at least as keenly sensitive as the modern. But it is the "infinite plus " always attached to the violation of taboo that puts it into the realm of the mystical, the magical. It would seem that Dr. Frazer's definition does not include enough.

It is when we turn to the subject of this study that we see most clearly the deficiencies in these explanations-to the "classic well-nigh universal major taboo" of the woman shunned. Dr. Marett uses her as his most telling argument 


\section{TABOO AND GENETICS}

against the inclusiveness of the concepts of Dr. Frazer and of MM. Hubert and Mauss. He says : "It is difficult to conceive of sympathy, and sympathy only, as the continuous, or even the originally efficient cause of the avoidance." Mr Crawley had called attention to the fact that savages fear womanly characteristics, that is, effeminacy, which is identified with weakness. While noting with great psychological insight the presence of other factors, such as the dislike of the different, he had gone so far as to express the opinion that the fear of effeminacy was probably the chief factor in the Sex Taboo. This is probably the weakest point in Mr. Crawley's study, for he shows so clearly the presence of other elements, notably mystery, the element that made woman the potential witch against whom suspicion concentrated in so tragical a fashion up to a late historical period.

Because of the element of mystery present in taboo we are led to conclude that taboo is more than negative magic if we accept so definite a concept as " a false association of ideas." The presence of power in the tabooed object turns our attention to mana as giving us a better understanding of why man must be wary. Mana must however be liberally interpreted if we are to see to the bottom of the mystery. It must be thought of as including good as well as evil power, as more than the "black magic" of the 
witch-haunted England of the I7th century, as is shown by the social position of the magicians who deal with the Mana of the Pacific and with the Orenda of the Iroquois. It implies "wonder-working," and may be shown in sheer luck, in individual cunning and power, or in such a form as the "uncanny" psychic qualities ascribed to women from the dawn of history. With this interpretation of mana in mind, taboo may be conceived as negative mana; and to break taboo is to set in motion against oneself mystic wonder-working power.

Our study thus far has made it clear that there are mystic dangers to be guarded against from human as well as extra-human sources. There is weakness to be feared as well as power, as shown by the food and sex taboos And once again there is mystery in the different, the unusual, the unlike, that causes avoidance and creates taboos. Man's dislike of change from the old well-trodden way, no matter how irrational, accounts for the persistence of many ancient folkways (6) whose origins are lost in mystery.* Many of these old and persistent avoidances have been expanded in the develop-

*Prof. Franz Boas explains this tendency : "The more frequently an action is repeated, the more firmly it will become established ... So that customary actions which are of frequent repetition become entirely unconscious. Hand in hand with this decrease of consciousness goes an increase in the emotional value of the omission of these activities, and still more of the performance of acts contrary to custom." 


\section{TABOO AND GENETICS}

ment of social relationships until we agree with Mr. Crawley that taboo shows that "man seems to feel that he is treading in slippery places." Might it not be within the range of possibility that in the study of taboo we are groping with man through the first blind processes of social control ?*

It is worthy of note that the most modern school of analytical psychology has recently turned attention to the problem of taboo. Prof. Sigmund Freud, protagonist psychoanalysis, in an essay, Totem und Tabu, called attention to the analogy between the dualistic attitude toward the tabooed object as both sacred and unclean and the ambivalent attitude of the neurotic toward the salient objects in his environment. We must agree that in addition to the dread of the tabooed person or object there is often a feeling of fascination. This is of course particularly prominent in the

* No study of the tabu-mana theory, however delimited its field, can disregard the studies of religion and magic made by the contributors to L'Année Sociologique, notably MM. Durkheim and Levy-Bruhl, and in England by such writers as Sir Gilbert Murray, Miss Harrison, Mr A. B. Cook, Mr F. M. Cornford, and others. In their studies of " collective representations" these writers give us an account of the development of the social obligation back of religion, law, and social institutions. They posit the sacred as forbidden and carry origins back to a pre-logical stage, giving as the origin of the collective emotion that started the representations to working the re-enforcement of power or emotion resulting from gregarious living. This study is concerned, however, with a "social " rather than a "religious" taboo,- -if such a distinction can somewhat tentatively be made, with the admission that the social scruple very easily takes on a religious colouring. 
case of the woman tabooed because of the strength of the sex instinct. As Freud has very justly said, the tabooed object is very often in itself the object of supreme desire. This is very obvious in the case of the food and sex taboos, which attempt to inhibit two of the most powerful impulses of human nature. The two conflicting streams of consciousness called ambivalence by the psychologist may be observed in the attitude of the savage toward many of his taboos. As the Austrian alienist cannily remarks, unless the thing were desired there would be no necessity to impose taboo restrictions concerning it.

It is by a knowledge of the mana concept and the belief in sympathetic magic, clarified by recognition of the ambivalent element in the emotional reaction to the thing tabooed, that we can hope to understand the almost universal custom of the "woman shunned" and the sex taboos of primitive peoples. This dualism appears most strongly in the attitude toward woman; for while she was the natural object of the powerful sexual instinct she was quite as much the source of fear because she was generally supposed to be endowed with spiritistic forces and in league with supernatural powers. During the long period when the fact of paternity was unrecognized, the power of reproduction which was thus ascribed to woman alone made 
of her a mysterious being. Her fertility could be explained only on the basis of her possession of an unusually large amount of mana or creative force, or by the theory of impregnation by demonic powers. As a matter of fact, both explanations were accepted by primitive peoples, so that woman was regarded not only as imbued with mana but also as being in direct contact with spirits. Many of the devices for closing the reproductive organs which abounded among savage tribes were imposed as a protection against spirits rather than against the males of the human species. The tradition of impregnation by gods or demons was not confined to savage tribes, but was wide-spread in the days of Greece and Rome and lasted into biblical times, when we read of the sons of heaven having intercourse with the daughters of men.

In addition to this fear of the woman as in possession of and in league with supernatural powers, there was an additional motive to avoidance in the fear of transmission of her weakness through contact, a fear based on a belief in sympathetic magic, and believed with all the " intensely realized, living, and operative assurance" of which the untutored mind is capable. Crawley masses an overwhelming amount of data on this point, and both he and Frazer show the strength of these beliefs. Indeed, in many cases violation proved to be 
"sure death," not by the hand of man, but from sheer fright. As a result, just as woman was considered to have both the tendency and power to impart her characteristics through contact, so the sexual act, the acme of contact, became the most potent influence for the emasculation of the male.

If we wish for proof that the primitive attitude toward women was essentially that which we have outlined, we have only to glance at the typical taboos concerning woman found among ancient peoples and among savage races of our own day. Nothing could be more indicative of the belief that the power to bring forth children was a manifestation of the possession of mana than the common avoidance of the pregnant woman. Her mystic power is well illustrated by such beliefs as those described by the traveller Im Thurn, who says that the Indians of Guiana believe that if a pregnant woman eat of game caught by hounds, they will never be able to hunt again. Similarly, Alfred Russell Wallace wrote of the aborigines of the Amazon: "They believe that if a woman during her pregnancy eats of any meat, any other animal partaking of it will suffer ; if a domestic animal or tame bird, it will die; if a dog, it will be for the future incapable of hunting; and even a man will be unable to shoot that particular kind of game for the future."

(8). In Fiji 


\section{TABOO AND GENETICS}

a pregnant wife may not wait upon her husband. (9). In the Caroline Islands men may not eat with their wives when pregnant, but small boys are allowed to do so. (IO).

The avoidance of the menstruous woman is an even more widespread custom than the shunning of pregnancy, probably because this function was interpreted as a symptom of demonic possession. Primitive man had no reason to know that the phenomenon of menstruation was in any way connected with reproduction. The typical explanation was probably very much like that of the Zoroastrians, who believed that the menses were caused by the evil god Ahriman. A woman during the period was unclean and possessed by that demon. She must be kept confined and apart from the faithful, whom her touch would defile, and from the fire, which her very look would injure. To this day there is in the house of the Parsee a room for the monthly seclusion of the women, bare of all comforts, and from it neither sun, moon, stars, fire, water, nor any human being can be seen. (II).

All the ancient civilizations had such taboos upon the menstruous woman. According to Pliny, the Romans held that nothing had such marvellous efficacy as, or more deadly qualities than, the menstrual flow. The Arabs thought that a great variety of natural powers attached 
themselves to a woman during the menstrual period. (I2: p. 448). Rabbinic laws demand that "a woman during all the days of her separation shall be as if under a ban." The epithet Niddah, applied to a woman at that time, means "to lay under a ban." The reconstruction of the ancient Assyrian texts shows that the law of the unclean taboo on the woman in her courses holds for them. Up to the present time the Semitic woman is carefully segregated from the rest of the tribe, often for a long time, and becomes taboo again on each successive occasion. (13). Peoples in the eastern Mediterranean region will not permit a woman in her courses to salt or pickle; whatever she might perpare would not keep. This belief survives among the folk to-day in America, and was evidently brought early in the history of the country, for it is common among pioneer stock.

There are very similar taboos among the savage races. Among the Tshi peoples of West Africa women are not allowed to remain even in the town but retire at the period to huts erected for the purpose in the neighbouring bush, because they are supposed to be offensive to the tribal deities at that time. (I4). The Karoks of California have a superstition like that of the Israelites. Every month the woman is banished without the village to live in a booth 
by herself. She is not permitted to partake of any meat, including fish. If a woman at this time touches or even approaches any medicine which is about to be given to a sick man, it will cause his death. (I5). Amongst other Indian tribes of North America women at menstruation are forbidden to touch men's utensils, which would be so defiled by their touch that their subsequent use would be attended by certain misfortune. The Canadian Dénés believe that the very sight of a woman in this condition is dangerous to society, so that she wears a special skin bonnet to hide her from the public gaze (I6). In western Victoria a menstruous woman may not take anyone's food or drink, and no one will touch food that has been touched by her. (I 7 ). Amongst the Maoris, if a man ate food cooked by a menstrous woman, he would be "tapu an inch thick." (I8). Frazer quotes the case of an Australian blackfellow who discovered that his wife had lain on his blanket at her menstrual period, and who killed her and died of terror himself within a fortnight. (I9). Australian women at this time are forbidden on pain of death to touch anything that men use or even to walk on a path that men frequent. (20). Among the Baganda tribes a menstruous woman is not permitted to come near her husband, cook his food, touch any of his weapons, or sit on his mats, bed, or seat. (2I). 
By some twist in the primitive way of thinking, some "false association by similarity and contiguity," the function of childbirth, unlike that of pregnancy, where the emphasis seems to have been placed in most cases on the mana principle, was held to be unclean and contaminating, and was followed by elaborate rites of purification. It may be that the pains of delivery were ascribed to the machinations of demonic powers, or possession by evil spirits, -we know that this has sometimes been the case. The use of charms and amulets, and the chanting of sacred formulæ at this dangerous time all point to such beliefs. At any rate, although the birth of the child would seem in every respect except in the presence of blood to be more closely connected with the phenomena of pregnancy than with that of menstruation, as a matter of fact the taboos on the woman in child-bed were intimately associated with those on menstruous women.

Among the ancients, the Zoroastrians considered the woman unclean at childbirth as at menstruation. (22). In the Old Testament, ritual uncleanness results from contact with a woman at childbirth. (23).

Likewise among savage tribes the same customs concerning childbirth prevail. Among the Australian aborgines women are secluded at childbirth as at menstruation, and all vessels 
used by them during this seclusion are burned. (20). The Ewe-speaking people think a mother and babe unclean for forty days after childbirth. (24). At menstruation and childbirth a Chippeway wife may not eat with her husband; she must cook her food at a separate fire, since any one using her fire would fall ill. (Io: v. ii, p. 457). The Alaskan explorer Dall found that among the Kaniagmuts a woman was considered unclean for several days both after delivery and menstruation; in either case no one may touch her and she is fed with food at the end of a stick. (25). Amongst the tribes of the Hindu Kush the mother is considered unclean for seven days after the birth of her child, and no one will eat from her hand nor will she suckle her infant during that period. In the Oxus valley north of the Hindu Kush the period is extended to forty days. (26.)

This attitude which primitive man takes toward woman at the time of her sexual crises -menstruation, pregnancy, childbirth-are but an intensification of the feeling which he has toward her at all times. Conflicting with his natural erotic inclinations are the emotions of awe and fear which she inspires in him as the potential source of contagion, for there is always some doubt as to her freedom from bad magic, and it is much safer to regard her as unclean. (27). Thus the every-day life of savage tribes 
is hedged in by all manner of restrictions concerning the females of their group. The men have their own dwelling in many instances, where no woman may enter. So, too, she may be barred out from the temples and excluded from the religious ceremonies when men worship their deity. There are people who will not permit the women of their nation to touch the weapons, clothing, or any other possessions of the men, or to cook their food, lest even this indirect contact result in emasculation. The same idea of sympathetic magic is at the root of taboos which forbid the wife to speak her husband's name, or even to use the same dialect. With social intercourse debarred, and often no common table even in family life, it is veritably true that men and women belong to two castes.

Of the primitive institution known as the " men's house," Hutton Webster says : " Sexual separation is further secured and perpetuated by the institution known as the men's house, of which examples are to be found among primitive peoples throughout the world. It is usually the largest building in a tribal settlement .. Here the most precious belongings of the community, such as trophies and religious emblems, are preserved. Within its precincts . . women and children . . . seldom or never enter . . Family huts serve as little more than resorts for the women and children." (28). 
Many examples among uncivilized peoples bear out this description of the institution of the men's house. Amongst the Indians of California and in some Redskin tribes the men's clubhouse may never be entered by a squaw under penalty of death. The Shastika Indians have a town lodge for women, and another for men which the women may not enter. (I5). Among the Fijis women are not allowed to enter a bure or club house, which is used as a lounge by the chiefs. In the Solomon Islands women may not enter the men's tambu house, and on some of the islands are not even permitted to cross the beach in front of it. (29). In the Marquesas Islands the $t i$ where the men congregate and spend most of their time is taboo to women, and protected by the penalty of death from the pollution of a woman's presence. (30).

Not only is woman barred from the men's club house, but she is also often prohibited from association and social intercourse with the opposite sex by many other regulations and customs. Thus no woman may enter the house of a Maori chief (3I), while among the Zulus, even if a man and wife are going to the same place they never walk together. (32). Among the Baganda wives are kept apart from the men's quarters. (2I). The Ojibway Indian Peter Jones says of his people: "When travelling the men always walk on before. It would be 
considered a great presumption for the wife to walk by the side of her husband. (33). In many islands of the South Seas the houses of important men are not accessible to their wives, who live in separate huts. Among the Bedouins a wife may not sit in any part of the tent except her own corner, while it is disgraceful for a man to sit under the shadow of the women's roffe (tent covering). (34). Among the Hindus, no female may enter the men's apartments. In the Society and Sandwich Islands the females were humiliated by taboo, and in their domestic life the women lived almost entirely by themselves. The wife could not eat the same food, could not eat in the same place, could not cook by the same fire. It was said that woman would pollute the food. (35). In Korea a large bell is tolled at about 8 p.m. and 3 a.m. daily, and between these hours only are women supposed to appear in the streets. (36). In the New Hebrides there is a curious segregation of the sexes, with a dread among the men of eating anything female. (37).

Among many tribes this segregation of the women and the separation of the sexes begin at an early age, most often at the approach of puberty, which is earlier in primitive peoples than in our own race. (38). The boys usually go about with the father, while the girls remain with the mother. This is true in Patagonia, 


\section{TABOO AND GENETICS}

where the boys begin to go with the father at ten, the daughters with the mother at nine. (39). In Korea boys and girls are separated at seven. From that time the Korean girl is absolutely secluded in the inner court of her father's home. Mrs Bishop says: "Girl children are so successfully hidden away that ... I never saw one girl who looked above the age of six ... except in the women's rooms." (36). Among the northern Indian girls are from the age of eight or nine prohibited from joining in the most innocent amusements with children of the opposite sex, and are watched and guarded with such an unremitting attention as cannot be exceeded by the most rigid discipline of an English boarding-school. (40). Similar arrangements are reported among the Hill Dyaks (4I), certain Victorian tribes (I 7 ), and many others. As already instanced, the separation of the sexes extends even to brothers and sisters and other close relatives. Thus in Fiji brothers and sisters are forbidden by national and religious custom to speak to each other. (9). In Melanesia, according to Codrington, the boy begins to avoid his mother when he puts on clothing, and his sister as soon as she is tattooed. (42). In the exclusive Nanburi caste of Travancore brothers and sisters are separated at an early age.

Women are more often than not excluded 
also from religious worship on account of the idea of their uncleanness. The Arabs in many cases will not allow women religious instruction. The Ansayrees consider woman to be an inferior being without a soul, and therefore exclude her from religious services. (34). In the Sandwich Islands women were not allowed to share in worship or festivals. (35). The Australians are very jealous lest women should look into their sacred mysteries. It is death for a woman to look into a Bora. (20). In Fiji women are kept away from worship and excluded from all the temples. (9). The women of some of the Indian hill-tribes may not sacrifice nor appear at shrines, nor take part in religious festivals. In New Ireland women are not allowed to approach the temples. (43). In the Marquesas Islands the Hoolah-hoolah ground, where festivals are held, is taboo to women, who are killed if they enter or even touch with their feet the shadow of the trees: (30). Women are also excluded from the sacred festivals of the Ahts. (44). In the Amazon region, the women are not even permitted to see the objects used in important ceremonies. If any woman of the Uaupes tribe happens to see the masks used in the tribal ceremony she is put to death. (45).

Crawley has explained the taboos on the sexes eating together and on the cooking of food 


\section{TABOO AND GENETICS}

by women for men as due to the superstitious belief that food which has come in contact with or under the influence of the female is capable of transmitting her properties. Some southern Arabs would die rather than accept food from a woman. (12). Among the old Semites it was not the custom for a man to eat with his wife and children. Among the Motu of New Guinea when a man is helega, he may not eat food that his wife has cooked. (46). South Australian boys during initiation are forbidden to eat with the women, lest they "grow ugly or become grey."

It was probably some fear of the charmweaving power of woman which lay at the root of the rules which forbade her to speak her husband's name, the implication being that she might use it in some incantation against him. For instance, a Zulu woman was forbidden to speak her husband's name; if she did so, she would be suspected of witchcraft. (47). Herodotus tells us that no Ionian woman would ever mention the name of her husband, nor may a Hindu woman do so.

(48).

Frazer says that the custom of the Kaffir woman of South Africa not to speak the name of her own or husband's relations has given rise to an almost entirely different language from that of the men through the substitution of new words for the words thus banned. Once 
this " women's speech" had arisen, it would of course not besused by the men because of the universal contempt for woman and all that pertained to her. This may have been the origin of the use of different dialects in some tribes, such as the Japanese, the Arawaks, some Brazilian tribes, and others. (49).

Although the division of labour between the sexes had a natural biological basis, and indeed had its beginning in the animal world long before man as such came into existence, the idea of the uncleanness of woman was carried over to her work, which became beneath the dignity of man. As a result, there grew up a series of taboos which absolutely fixed the sphere of woman's labour, and prohibited her from encroaching on the pursuits of man lest they be degraded by her use, quite as much as they barred man from her specific activities. In Nicaragua, for example, it is a rule that the marketing shall be done by women. In Samoa, where the manufacture of cloth is allotted to the women, it is taboo for a man to engage in any part of the process. (30). Among the Andamanese the performance of most of the domestic duties falls to the lot of the women and children. Only in cases of stern necessity will the husband procure wood or water. (50). An Eskimo even thinks it an indignity to row in an umiak, the large boat used by women. 
They also distinguish very definitely between the offices of husband and wife. For example, when a man has brought a seal to land, it would be a stigma on his character to draw it out of the water, since that is the duty of the female. (5I). In the Marquesas Islands, the use of canoes in all parts of the islands is rigorously prohibited to women, for whom it is death even to be seen entering one when hauled on shore; while Tapa-making, which belongs exclusively to women, is taboo to men. (30). Among the Betchuanas of South Africa the men will not let women touch the cattle. (52). The Baganda think that if a woman steps over a man's weapons they will not aim straight or kill until they have been purified. (2I). Among many South African tribes, if a wife steps over her husband's assegais, they are considered useless from that time and are given to the boys to play with. This superstition rings many changes and is current among the natives of all countries.

The taboos which have thus been exemplified and reviewed are based on the feeling that woman is possessed of a demonic power, or perhaps of a mana principle which may work injury; or else upon the fear that she may contaminate man with her weakness. It is very probable that many of these taboos originated even as far back as the stage of society in which the line of descent was traced through the 
mother. There seems little doubt that the framework of ancient society rested on the basis of kinship, and that the structure of the ancient gens brought the mother and child into the same gens. Under these circumstances the gens of the mother would have some ascendancy in the ancient household. On such an established fact rests the assumption of a matriarchate, or period of Mutterrecht. The German scholar Bachofen in his monumental work "Das Mutterrecht" discussed the traces of female " authority" among the Lycians, Cretans, Athenians, Lemnians, Lesbians, and Asiatic peoples. But it is now almost unanimously agreed that the matriarchal period was not a time when women were in possession of political or economic power, but was a method of tracing descent and heritage. It is fairly well established that, in the transition from metronymic to patronymic forms, authority did not pass from women to men, but from the brothers and maternal uncles of the women of the group to the husbands and sons. Such a method of tracing descent, while it doubtless had its advantages in keeping the woman with her child with her blood kindred, would not prevent her from occupying a degraded position through the force of the taboos which we have described. (53).

With the development of the patriarchal system and the custom of marriage by capture 
or purchase, woman came to be regarded as a part of man's property, and as inviolate as any other of his possessions. Under these circumstances virginity came to be more and more of an asset, since no man wished his property to be defiled by the touch of another. Elaborate methods for the preservation of chastity both before and after marriage were developed, and in many instances went so far as to consider a woman defiled if she were accidentally touched by any other man than her husband. Here we have once more the working of sympathetic magic, where the slightest contact works contamination.

We have in other connections alluded to the seclusion of young girls in Korea, among the Hindus, among the North American Indians, and in the South Seas. One of the most beautiful examples of this custom is found in New Britain. From puberty until marriage the native girls are confined in houses with a bundle of dried grass across the entrance to show that the house is strictly taboo. The interior of these houses is divided into cells or cages in each of which a girl is confined. No light and little or no air enters, and the atmosphere is hot and stifling.

The seclusion of women after marriage is common among many peoples. In the form in which it affected western civilization it probably originated among the Persians or some other 
people of central Asia, and spread to the Arabs and Mohammedans. That it did not originate with the Arabs is attested by students of their culture. It was common among the Greeks, whose wives were secluded from other men than their husbands. In modern Korea it is not even proper to ask after the women of the family. Women have been put to death in that country when strange men have accidentally touched their hands. (36: p. 34I).

The saddest outcome of the idea of woman as property was the status of widows. In uncivilized society a widow is considered dangerous because the ghost of her husband is supposed to cling to her. Hence she must be slain that his spirit may depart in peace with her, as well as with the weapons and other possessions which are buried with him or burned upon his funeral pyre. The Marathi proverb to the effect that "the husband is the life of the woman" thus becomes literally true.

The best known case of widow slaying is of course the custom of " suttee " in India. The long struggle made against this custom by the British government is a vivid illustration of the strength of these ancient customs. The Laws of Manu indicate that the burning of widows was practised by primitive Aryans. In the Fiji Islands, where a wife was strangled on her husband's grave, the strangled women 
were called "the carpeting of the grave." (54.) In Arabia, as in many other countries, while a widow may escape death, she is very often forced into the class of vagabonds and dependents. One of the most telling appeals made by missionaries is the condition of child widows in countries in which the unfortunates cannot be killed, but where the almost universal stigma of shame is attached to second marriages. A remarkable exception to this, when in ancient Greece the dying husband sometimes bequeathed his widow to a male friend, emphasized the idea of woman as property.

Although the taboos which are based on the idea of ownership are somewhat aside from the main theme of our discussion, they nevertheless reinforce the other taboos of the seclusion and segregation of woman as unclean. Moreover, as will be shown in a later chapter, the property idea has certain implications which are important for the proper understanding of the status of woman and the attitude toward her at the present time.

In the face of the primitive aversion to woman as the source of contamination through sympathetic magic, or as the seat of some mystic force, whether of good or evil, it may well be asked how man ever dared let his sexual longings overcome his fears and risk the dangers of so intimate a relationship. Only by some religious 
ceremonial, some act of purification, could man hope to counteract these properties of woman; and thus the marriage ritual came into existence. By the marriage ceremonial, the breach of taboo was expiated, condoned, and socially countenanced. (I : p. 200). This was very evident in the marriage customs of the Greeks, which were composed of purification rites and other precautions. (55). The injunctions to the Hebrews given in Leviticus illustrate the almost universal fact that even under the sanction of marriage the sexual embrace was taboo at certain times, as for example before the hunt or battle.

We are now prepared to admit that throughout the ages there has existed a strongly dualistic or " ambivalent " feeling in the mind of man toward woman. On the one hand she is the object of erotic desire; on the other hand she is the source of evil and danger. So firmly is the latter feeling fixed that not even the sanction of the marriage ceremony can completely remove it, as the taboos on intercourse within the marital relationship show.

There are certain psychological and physiological reasons for the persistence of this dualistic attitude in the very nature of the sex act itself. Until the climax of the sexual erethism, woman is for man the acme of supreme desire; but with detumescence the emotions 
tend to swing to the opposite pole, and excitement and longing are forgotten in the mood of repugnance and exhaustion. This tendency would be very much emphasized in those primitive tribes where the corroboree with its unlimited indulgence was common, and also among the ancients with their orgiastic festivals. In the revulsion of feeling following these orgies woman would be blamed for man's own folly. In this physiological swing from desire to satiety, the apparent cause of man's weakness would be looked upon as the source of the evil-a thing unclean. There would be none of the ethical and altruistic element of modern "love" to protect her. Students agree that these elements in the modern sentiment have been evolved, " not from the sexual instinct, but from the companionship of the battlefield." (56). It is therefore probable that in this physiological result of uncontrolled sex passion we shall find the source of the dualism of the attitude toward sex and womanhood present in taboo.

\section{BIBLIOGRAPHY FOR CHAPTER I}

I. Crawley, A. E. The Mystic Rose. 492 pp. Macmillan. London, I902.

2. Jevons, F. B. History of Religion. 443 pp. Methuen \& Co. London, 1896 .

3. Tylor, E. B. Early History of Mankind, 3d. ed. 388 pp. J. Murray. London, 1878.

4. Frazer, J. G. The Golden Bough: Part I, The Magic 


\section{TABOO AND GENETICS}

Art and the Evolution of Kings. 2 vols. Macmillan. London, I9II.

5. First published in Anthropological Essays presented to E. B. Tylor in honour of his $75^{\text {th }}$ birthday. Oct. 2, I907. 4 I6 pp. The Clarendon Press, Oxford, I907.

6. Sumner, W. G. Folkways. 692 pp. Ginn \& Co. Boston, I907.

7. Boas, Franz. The Mind of Primitive Man. 294 pp. Macmillan. N. Y., IgII.

8. Wallace, Alfred Russel. Narrative of Travels on the Amazon and Rio Negro. 54I pp. Reeve \& Co., London, I853.

9. Williams, Thomas, and Calvert, James. Fiji and the Fijians. 55 I pp. Appleton. N. Y., I859.

Io. Ploss, Dr Hermann H. Das Weib. 2 vols. Th. Grieben's Verlag. Leipzig, I885.

II. Greiger, Ostiranische Kultur. Erlangen, I882. Quoted from Folkways (6), p. 5 I3.

I2. Robertson Smith, W. Religion of the Semites. 508 pp. A. \& C. Black. Edinburgh, I894.

I3. Thompson, R. C. Semitic Magic. 286 pp. Luzac \& Co. London, Igo8.

I4. Ellis, A. B. Tshi-speaking Peoples of the Gold Coast of West Africa. 343 pp. Chapman \& Hall. London, I887.

I5. Powers, Stephen. Tribes of California. Contributions to North American Ethnology, Third Volume. Washington, I877.

I6. Morice, Rev. Father A. G. The Canadian Dénés. Annual Archeological Report, I905. Toronto, Igo6. Quoted from Frazer, Taboo and the Perils of the Soul.

I7. Dawson, James. Australian Aborigines. III pp., with Appendix. George Robertson. Melbourne, Sydney, and Adelaide, I88r. Citation from Latin note to Chap. XII. 
I8. Tregear, Edward. The Maoris of New Zealand. Journal of the Anthropological Institute, v. xix, I889. I9. Armit, Capt. W. E. Customs of the Australian Aborigines. Jour. Anthr. Inst., ix, I880, p. 459. See also (I8).

20. Ridley, W. Report on Australian Languages and Traditions. Jour. Anthr. Inst., ii, I872.

2I. Roscoe, Rev. John. Manners and Customs of the Baganda. Jour. Anthr, Inst., xxxii, I902.

22. Zend-Avesta. Sacred Books of the East Series. Oxford I880, I883.

23. Leviticus xii.

24. Ellis, A. B. Ewe-speaking Peoples of the Slave Coast of West Africa. Chapman \& Hall. London, I8go. 33I pp.

25. Dall, W. H. Alaska and Its Resources. 627 pp. Lee \& Shepard. Boston, I870.

26. Biddulph, Maj. J. Tribes of the Hindoo Koosh. I64 Pp. Gov't. Printing Office. Calcutta, I880.

27. Frazer, J. G. The Golden Bough: Part II, Taboo and the Perils of the Soul. $446 \mathrm{pp}$. Macmillan. London, IgrI.

28. Webster, Hutton. Primitive Secret Societies. 227 pp. Macmillan. N. Y., 1908.

29. Guppy, H. B. The Solomon Islands and Their Natives. 384 pp. Swan Sonnenschein \& Co. London, I887.

3o. Melville, $\mathrm{H}$. The Marquesas Islands. $285 \mathrm{pp}$. John Murray. London, I846.

3r. Taylor, Rev. Richard. Te Ika A Maui, or New Zealand and Its Inhabitants. 7I3 pp. 2d. ed. Macintosh. London, I870.

32. Shooter, Rev. Joseph. The Kaffirs of Natal and the Zulu Country. 403 pp. E. Stanford. London, I 857 .

33. Jones, Rev. Peter. History of the Ojibway Indians.

217 pp. A. W. Bennett. London, I86r. 
34. Featherman, A. Social History of the Races of Mankind. 5 vols. Trübner \& Co. London, I88I.

35. Ellis, Rev. Wm. Polynesian Researches. 4 vols. G. Bohn. London, I853.

36. Bishop, Mrs Isabella Bird. Korea and Her Neighbours. 480 pp. Fleming H. Revell Co. N. Y., I 898 .

37. Somerville, Lieut. Boyle T. The New Hebrides. Jour. Anthr. Inst, xxiii, I894.

38. Hall, G. Stanley. Adolescence. 2 vols. Appleton, N. Y., I904.

39. Musters, G. C. At Home with the Patagonians. $340 \mathrm{pp}$. J. Murray. London, I873.

40. Hearne, Samuel. A Journey from Prince of Wales's Fort in Hudson's Bay to the Northern Ocean. Publications of the Champlain Society, No. 6. London, I795.

4I. Low, Hugh. Sarawak. 4 I6 pp. Richard Bentley. London, I848.

42. Codrington, Rev. R. H. The Melanesians. 4 Ig pp. Oxford, I89I.

43. Romilly, Hugh Hastings. The Western Pacific and New Guinea, 2d. ed., 284 pp. John Murray. London, I887.

44. Sproat, G. M. Scenes and Studies of Savage Life. 3I7 pp. Smith, Elder \& Co. London, I 868.

45. Wissler, Clark. The American Indian. 435 pp. D. C. McMurtrie. N. Y., I9I7.

46. Lawes, W. G. Ethnographical Notes on the Motu, Koitapu, and Koiari Tribes of New Guinea. Jour. Anthr. Inst., viii, I879.

47. Callaway, Rev. Canon Henry. Religious System of the Amazulu. 448 pp. Trübner \& Co. London, I870. 48. Crooke, W. Popular Religion and Folklore of Northern India. 2 vols. Archibald Constable \& Co. Westminster, 1896.

49. Crawley, A. E. Sexual Taboo. Journ. Anthr. Inst., xxiv, I895. 


\section{TABOO AND GENETICS}

50 Man, E. H. The Aboriginal Inhabitants of the Andaman Islands. Jour. Anthr. Inst., xii, I882.

5I. Crantz, David. History of Greenland. Trans. fr. the German, 2 vols. Longmans, Green. London, I8.20.

52. Holub, E. Central South African Tribes. Jour. Anthr. Inst., x, I88r.

53. Morgan, Lewis H. Ancient Society. 560 pp. Henry Holt \& Co. N. Y., I907. (First edition, 1877).

54. Fison, Rev. Lorimer. Figian Burial Customs. Jour. Anthr. Inst., x. I88I.

55. Rohde, Erwin. Psyche. 7II pp. Freiburg und Leipzig, I894.

56. Benecke, E. F. M. Women in Greek Poetry. 256 pp. Swan Sonnenschein \& Co. London, I8g6. 


\section{CHAPTER II}

\section{FROM THE DAWN OF HISTORY : WOMAN AS SAINT AND WITCH}

Taboos of first chapter indicate that in the early ages the fear of contamination by woman predominated ; Later, emphasis fell on her mystic and uncanny power; Ancient fertility cults; Temple prostitution, dedication of virgins, etc. ; Ancient priestesses and prophetesses ; Medicine early developed by woman added to belief in her power; Woman's psychic quality of intuition : its origin-theories-conclusion that this quality is probably physiological in origin, but aggravated by taboo repressions; Transformation in attitude toward woman in the early Christian period; Psychological reasons for the persistence in religion of a Mother Goddess; Development of the Christian concept; Preservation of ancient women cults as demonology ; Early Christian attitude toward woman as unclean and in league with demons; Culmination of belief in demonic power of woman in witchcraft persecutions ; All women affected by the belief in witches and in the uncleanness of woman; Gradual development on the basis of the beliefs outlined of an ideally pure and immaculate Model Woman.

From the data of the preceding chapter, it is clear that in the early ages of human life there was a dualistic attitude toward woman. On the one hand she was regarded as the possessor of 
the mystic mana force, while on the other she was the source of "bad magic" and likely to contaminate man with her weaknesses. Altogether, the study of primitive taboos would indicate that the latter conception predominated in savage life, and that until the dawn of history woman was more often regarded as a thing unclean than as the seat of a divine power.

At the earliest beginnings of civilization man's emotions seem to have swung to the opposite extreme, for emphasis fell on the mystic and uncanny powers possessed by woman. Thus it was that in ancient nations there was a deification of woman which found expression in the belief in feminine deities and the establishment of priestess cults. Not until the dawn of the Christian era was the emphasis once more focussed on woman as a thing unclean. Then, her mystic power was ascribed to demon communication, and stripped of her divinity, she became the witch to be excommunicated and put to death.

All the ancient world saw something supernatural, something demoniacal, in generation. Sometimes the act was deified, as in the phallic ceremonials connected with nature worship, where the procreative principle in man became identified with the creative energy pervading all nature, and was used as a magic charm at the time of springtime planting to insure the 


\section{I48 TABOO AND GENETICS}

fertility of the fields and abundant harvest.

It was also an important part of the ritual in the Phrygian cults, the cult of the Phœnician Astarte, and the Aphrodite cults. These mystery religions were widely current in the GræcoRoman world in pre-Christian times. The cult of Demeter and Dionysius in Greece and Thrace ; Cybele and Attis in Phrygia; Atagartes in Cilicia; Aphrodite and Adonis in Syria; Ashtart and Eshmun (Adon) in Phœnicia; Ishtar and Tammuz in Babylonia; Isis, Osiris and Serapis in Egypt, and Mithra in Persia-all were developed along the same lines. (2.) The custom of the sacrifice of virginity to the gods, and the institution of temple prostitution, also bear witness to the sacred atmosphere with which the sex act was surrounded among the early historic peoples. (3.) It was this idea of the mysterious sanctity of sex which did much to raise woman to her position as divinity and fertility goddess.

The dedication of virgins to various deities, of which the classic example is the institution of the Vestal Virgins at Rome, and the fact that at Thebes and elsewhere even the male deities had their priestesses as well as priests, are other indications that at this time woman was regarded as divine or as capable of ministering to divinity. The prophetic powers of woman were universally recognized. The oracles at 


\section{TABOO AND GENETICS}

Delphi, Argos, Epirus, Thrace and Arcadia were feminine. Indeed the Sibylline prophetesses were known throughout the Mediterranean basin.*

The widespread character of the woman-cult of priestesses and prophetesses among the peoples from whom our culture is derived is evidenced in literature and religion. That there had been cults of ancient mothers who exerted moral influence and punished crime is shown by the Eumenides and Erinyes of the Greeks. The power of old women as law-givers survived in Rome in the legend of the Cumæan Sibyl. (5.) An index of the universality of the sibylline cult appears in the list of races to which Varro and Lactantius say they belonged: Persian, Libyan, Delphian, Cimmerian, Erythrian, Trojan, and Phrygian. (6.) These sibyls were believed to be inspired, and generations of Greek and Roman philosophers never doubted their power. Their carmina were a court of last resort, and their books were guarded by a sacred taboo.

* Farnell (4) found such decided traces of feminine divinity as to incline him to agree with Bachofen that there was at one time an age of Mutterrecht which had left its impress on religion as well as on other aspects of social life. As we have said before, it is now fairly well established that in the transition from metronymic to patronymic forms, anthority did not pass from women to men but from the brothers and maternal uncles of the women of the group to husbands and sons. This fact does not, however, invalidate the significance of Farnell's data for the support of the view herein advanced, i.e., that woman was at one time universally considered to partake of the divine. 
Among the Greeks and neighbouring nations the women of Thessaly had a great reputation for their charms and incantations. (7.) Among the writers who speak of a belief in their power are: Plato, Aristophanes, Horace, Ovid, Virgil, Tibullus, Seneca, Lucan, Menander, and Euripides.

All of the northern European tribes believed in the foresight of future events by women. Strabo says of the Cimbri that when they took the field they were accompanied by venerable, hoary-headed prophetesses, clothed in long, white robes. Scandinavians, Gauls, Germans, Danes and Britons obeyed, esteemed and venerated females who dealt in charms and incantations. These sacred women claimed to foretell the future and to interpret dreams, and among Germans, Celts and Gauls they were the only physicians and surgeons. The druidesses cured disease and were believed to have power superior to that of the priests. (8.) The Germans never undertook any adventure without consulting their prophetesses. (9.) The Scandinavian name for women endowed with the gift of prophecy was fanae, fanes. The English form is fay. The ceremonies of fays or fairies, like those of the druidesses, were performed in secluded woods.*

Magic and medicine went hand in hand in

*Joan of Arc was asked during her trial if she wero a fay. 
ancient times, and remained together down to the middle ages. Old herbals largely compiled from the lore of ancient women form a link in the chain of tradition, the first ring of which may have been formed in Egypt or in Greece. There is no doubt that women from an early date tried to cure disease. Homer makes mention of Hecamede and her healing potions. There seems little doubt that there were Greek women who applied themselves to a complete study of medicine and contributed to the advance of medical science. This traditional belief in the power of women to cure disease survives in the folk to-day. (Io.)

In view of the widespread veneration of a peculiar psychic quality of woman, a power of prophecy and a property of divinity which has made her an object of fear and worship, it may be well to review the modern explanations of the origin of this unique feminine power. Herbert Spencer was of the opinion that feminine penetration was an ability to distinguish quickly the passing feelings of those around and was the result of long ages of barbarism during which woman as the weaker sex was obliged to resort to the arts of divination and to cunning to make up for her lack of physical force and to protect herself and her offspring. (II.) In like vein Käthe Schirmacher, a German feminist, says: "The celebrated intuition of woman is 
nothing but an astonishing refinement of the senses through fear... Waiting in fear was made the life task of the sex." (I2.)

Lester F. Ward had a somewhat different view. (I3.) He thought that woman's psychic power came from the sympathy based on the maternal instinct, which "though in itself an entirely different faculty, early blended with or helped to create, the derivative reason-born faculty of altruism." With Ward's view Olive Schreiner agrees, saying: "We have no certain proof that it is so at present, but woman's long years of servitude and physical subjection, and her experience as childbearer and protector of infancy, may be found in the future to have endowed her... with an exceptional width of human sympathy and instinctive comprehension." (I4.)

In all probability Lombroso came nearer to the truth in his explanation of feminine penetration. "That woman is more subject to hysteria is a known fact," he says, "but few know how liable she is to hypnotic phenomena, which easily opens up the unfoldment of spiritual faculties. . . The history of observation proves that hysteria and hypnotism take the form of magic, sorcery, and divination or prophecy, among savage peoples. 'Women,' say the Pishawar peoples, "are all witches ; for several reasons they may not exert their inborn powers.' 


\section{TABOO AND GENETICS}

... In the Slave Coast hysterical women are believed to be possessed with spirits. The Fuegians believed that there had been a time when women wielded the empire through her possession of the secrets of sorcery." (8: pp. 85 f.)

The history of modern spiritualism has so well confirmed this view of Lombroso's that we are safe in accepting it as the partial explanation of the attribute of a mysterious and uncanny power which man has always given to the feminine nature. The power of prophecy and divination which was possessed by women at the dawn of history and for some time thereafter was probably not different in its essentials from the manifestations of hysterical girls who have puzzled the wisest physicians or the strange phenomena of those spiritualistic mediums who have been the subject of research well into our own times. (I5.)

If we wish to push our inquiry still further and ask why woman should be so much more subject than man to hysterical seizures and to hypnotic suggestion, we shall probably find that it is an essential part of her femininity. Modern psychology and physiology have pointed out that the menstrual cycle of woman has a vast influence not only on her emotional nature but on her whole psychic life, so that there are times when she is more nervously tense, more apt to become hysterical or to yield to the influence of 


\section{I54 TABOO AND GENETICS}

suggestion. Moreover, because of the emphasis on chastity and the taboos with which she was surrounded, any neurotic tendencies which might be inherent in her nature were sure to be developed to the utmost.

As Lombroso suggests, hysteria and other neurotic phenomena are classed as evidence of spirit possession by the untutored mind. Thus it happened that observing the strange psychic manifestations to which woman was periodically subject, the ancient peoples endowed her with spiritualistic forces which were sometimes held to be beneficent and at other times malefic in character. Whatever the attitude at any time whether her mana were regarded as evil or benignant, the savage and primitive felt that it was well to be on his guard in the presence of power; so that the taboos previously outlined would hold through the swing of man's mind from one extreme to the other.

As goddess, priestess and prophetess, woman continued to play her rôle in human affairs until the Christian period, when a remarkable transformation took place. The philosophy of dualism that emanated from Persia had affected all the religions of the Mediterranean Basin and had worked its way into Christian beliefs by way of Gnosticism, Manicheanism, and NeoPlatonism. Much of the writing of the church fathers is concerned with the effort to harmonize 
conflicting beliefs or to avoid the current heresies. To one who reads the fathers it becomes evident to what extent the relation of man to woman figures in these controversies. (I6.)

The Manicheanism which held in essence Persian Mithraism and which had so profound an influence on the writings of St. Augustine gave body and soul to two distinct worlds and finally identified woman with the body. But probably as a result of the teachings of Gnosticism with its Neo-Platonic philosophy which never entirely rejected feminine influence, some of this influence survived in the restatement of religion for the folk. When the restatement was completed and was spreading throughout Europe in the form which held for the next millennium, it was found that the early goddesses had been accepted among the saints, the priestesses and prophetesses were rejected as witches, while the needs of men later raised the Blessed Virgin to a place beside her son.

Modern psychology has given us an explanation of the difficulty of eradicating the worship of such a goddess as the Great Mother of Asia Minor from the religion of even martial peoples who fear the contamination of woman's weakness; or from a religion obsessed with hatred of woman as unclean by men who made the suppression of bodily passions the central notion 
of sanctity. The most persistent human relationship, the one charged with a constant emotional value, is not that of sex, which takes manifold forms, but that of the mother and child. It is to the mother that the child looks for food, love, and protection. It is to the child that the mother often turns from the mate, either because of the predominance of mother love over sex or in consolation for the loss of the love of the male. We have only recently learned to evaluate the infantile patterns engraved in the neural tissue during the years of childhood when the mother is the central figure of the child's life. Whatever disillusionments may come about other women later in life, the mother ideal thus established remains a constant part of man's unconscious motivations. It is perhaps possible that this infantile picture of a being all-wise, all-tender, all-sacrificing, has within it enough emotional force to create the demand for a mother-goddess in any religion.

To arrive at the concept of the Madonna, a far-reaching process of synthesis and reinterpretation must have been carried out before the Bible could be brought into harmony with the demands made by a cult of a mother goddess. Just as the views brought into the church by celibate ideals spread among heathen people, so the church must have been in its turn influenced by the heathen way of looking at things. 


\section{TABOO AND GENETICS}

(I7.) One of the great difficulties was the reconciliation of the biological process of procreation with divinity. But there had for ages been among primitive peoples the belief that impregnation was caused by spirit possession or by sorcery. This explanation had survived in a but slightly altered form in the ancient mythologies, all of which contained traditions of heroes and demi-gods who were born supernaturally of a divine father and a human mother. In the myths of Buddha, Zoroaster, Pythagoras and Plato, it was intimated that the father had been a god or spirit, and that the mother had been, and moreover remained after the birth, an earthly virgin. These old and precious notions of the supernatural origin of great men were not willingly renounced by those who accepted the new religion; nor was it necessary to make such a sacrifice, because men thought that they could recognize in the Jewish traditions something corresponding to the heathen legends. (I8.)

The proper conditions for the development of a mother cult within Christianity existed within the church by the end of the second century. At the Council of Nicæa (325 A. D.) it was settled that; the Son was of the same nature as the Father. The question of the nature of Mary then came to the fore. The eastern fathers, Athanasius, Ephraim Syrus, Eusebius 
and Chrysostom, made frequent use in their writings of the term Theotokos, Mother of God. When Nestorius attacked those who worshipped the infant Christ as a god and Mary as the mother of God rather than as the mother of Christ, a duel began between Cyril of Alexandria and Nestorius "which in fierceness and importance can only be compared with that between Arius and Athanasius." (I9.)

In 43 I A. D. the Universal Church Council at Ephesus assented to the doctrine that Mary was the Mother of God. Thus Ephesus, home of the great Diana, from primitive times the centre of the worship of a goddess who united in herself the virtues of virginity and motherhood, could boast of being the birthplace of the Madonna cult. And thus Mary, our Lady of Sorrows, pure and undefiled, "the church's paradox," became the ideal of man. She was " a woman, virgin and mother, sufficiently high to be worshipped, yet sufficiently near to be reached by affection. . . . If we judge myths as artistic creations we must recognize that no god or goddess has given its worshippers such an ideal as the Mary of Christian art and poetry." (I9: p. I83.) (20: v. ii., pp. 220f.)

Although Christianity thus took over and embodied in its doctrines the cult of the mothergoddess, at the same time it condemned all the rites which had accompanied the worship of the 


\section{TABOO AND GENETICS}

fertility goddesses in all the pagan religions. The power of these rites was still believed in, but they were supposed to be the work of demons, and we find them strictly forbidden in the early ecclesiastical laws. The phallic ceremonials which formed so large a part of heathen ritual became marks of the devil, and the deities in whose honour they were performed, although losing none of their power, were regarded as demonic rather than divine in nature. Diana, goddess of the moon, for example, became identified with Hecate of evil repute, chief of the witches. "In such a fashion the religion of Greece, that of Egypt, of Phœnicia and Asia Minor, of Assyria and of Persia, became mingled and confused in a simple demonology."

In addition to the condemnation of Pagan deities and their ritualistic worship, there was a force inherent in the very nature of Christianity which worked toward the degradation of the sex life. After the death of Christ, his followers had divorced their thoughts from all things earthly and set about fitting themselves for their places in the other world. The thought of the early Christian sects was obsessed by the idea of the second coming of the Messiah. The end of the world was incipient, therefore it behooved each and every one to purge himself from sin. This emphasis on the spiritual as opposed to the fleshly became fixated especially 
on the sex relationship, which came to be the symbol of the lusts of the body which must be conquered by the high desires of the soul. Consequently the feelings concerning this relation became surcharged with all the emotion which modern psychology has taught us always attaches to the conscious symbol of deeply underlying unconscious complexes. In such a situation man, who had come to look with horror on the being who reminded him that he was flesh as well as spirit saw in her "the Devil's gateway," or " a fireship continually striving to get along side the male man-of-war to blow him up into pieces." (22.)*

With the rejection of the idea of the sanctity of sex as embodied in the phallic rituals of the pagan cults, the psychic power of woman became once more a thing of fear rather than of worship, and her uncleanness was emphasized again more than her holiness, even as in primitive times. The power of woman to tell the course of future events which in other days had made her revered as priestess and prophetess now made her hated as a witch who had control of what the Middle Ages knew as the Black Art. (23.) The knowledge of medicine which

* Dr Donaldson, translator of the Ante-Nicene Fathers, says: "I used to believe . . . that woman owes her present position to Christianity . . but in the first three centuries I have not been able to see that Christianity had any favourable effect on the position of woman." 
she had acquired through the ages was now thought to be utilized in the making of " witch's brew," and the "ceremonies and charms whereby the influence of the gods might be obtained to preserve or injure " (2I : V. I, p. I2) became incantations to the evil one. In addition to her natural erotic attraction for the male, woman was now accused of using charms to lure him to his destruction. The asceticism of the church made it shameful to yield to her allurements, and as a result woman came to be feared and loathed as the arch-temptress who would destroy man's attempt to conform to celibate ideals. This sex antagonism culminated in the witchcraft persecutions which make so horrible a page of the world's history.

Among the pagans, witches had shared with prophetesses and priestesses a degree of reverence and veneration. Medea had taught Jason to tame the brazen-footed bulls and dragons which guarded the Golden Fleece. Hecate was skilled in spells and incantations. Horace frequently mentions with respect Canidia, who was a powerful enchantress. Gauls, Britons and Germans had obeyed and venerated women who dealt in charms and incantations. The doctrines of Christianity had changed the veneration into hatred and detestation without eradicating the belief in the power of the witch. It was with the hosts of evil that she was now believed to 
have her dealings, however. When this notion of the alliance between demons and women had become a commonplace, " the whole tradition was directed against woman as the Devil's instrument, basely seductive, passionate and licentious by nature." (24.) Man's fear of woman found a frantic and absurd expression in her supposed devil-worship. As a result, the superstitions about witchcraft became for centuries not only a craze, but a theory held by intelligent people.

Among the female demons who were especially feared were: Nahemah, the princess of the Succubi; Lilith, queen of the Stryges; and the Lamiæ or Vampires, who fed on the living flesh of men. Belief in the Vampires still persists as a part of the folklore of Europe. Lilith tempted to debauchery, and was variously known as child-strangler, child-stealer, and a witch who changed true offspring for fairy or phantom children.* The figure of the childstealing witch occurs in an extremely ancient apocryphal book called the Testament of Soloman, and dates probably from the first or second century of the Christian Era. (25.)

Laws against the malefici (witches) were passed by Constantine. In the Theodosian Code (Lib. 9. Tit. I6. Leg. 3.) they are

*The name of Lilith carries us as far back as Babylon, and in her charms and conjurations we have revived in Europe the reflection of old Babylonian charms. 
charged with making attempts by their wicked arts upon the lives of innocent men, and drawing others by magical potions (philtra et pharmaca) to commit misdemeanours. They are further charged with disturbing the elements, raising tempests, and practising abominable arts. The Council of Laodicea (343-38I. Can. 36) condemned them. The Council of Ancyra forbade the use of medicine to work mischief. St. Basil's canons condemned witchcraft. The fourth Council of Carthage censured enchantment. (26.) John of Salisbury tells of their feasts, to which they took unbaptized children. William of Auverne describes the charms and incantations which they used to turn a cane into a horse. William of Malmesbury gives an account of two old women who transformed the travellers who passed their door into horses, swine or other animals which they sold. From some of the old Teuton laws we learn that it was believed that witches could take a man's heart out of his body and fill the cavity with straw or wood so that he would go on living.

One of the famous witchcraft trials was that of the Lady Alice Kyteler (27), whose high rank could not save her from the accusation. It was claimed that she used the ceremonies of the church, but with some wicked changes. She extinguished the candles with the exclamation, "Fi! Fi! Fi! Amen!" She was also accused 
of securing the love of her husbands, who left much property to her, by magic charms. These claims were typical of the accusations against witches in the trials which took place.

By the sixteenth century, the cumulative notion of witches had penetrated both cultivated and uncultivated classes, and was embodied in a great and increasing literature. "No comprehensive work on theology, philosophy, history, law, medicine, or natural science could wholly ignore it," says Burr, "and to lighter literature it afforded the most telling illustrations for the pulpit, the most absorbing gossip for the news-letter, the most edifying tales for the fireside." (28.)

As a result of this belief in the diabolic power of woman, judicial murder of helpless women became an institution, which is thus characterized by Sumner : "After the refined torture of the body and nameless mental sufferings, women were executed in the most cruel manner. These facts are so monstrous that all other aberrations of the human race are small in comparison.... He who studies the witch trials believes himself transferred into the midst of a race which has smothered all its own nobler instincts, reason, justice, benevolence and sympathy." (24.)

Any woman was suspect. Michelet, after a thirty years' study, wrote: “Witches they are 


\section{TABOO AND GENETICS}

by nature. It is a gift peculiar to woman and her temperament. By birth a fay, by the regular recurrence of her ecstasy she becomes a sibyl. By her love she grows into an enchantress. By her subtlety . . . she becomes a witch and works her spells."

Just how many victims there were of the belief in the power of women as witches will never be known. Scherr thinks that the persecutions cost I00,000 lives in Germany alone. (30.) Lord Avebury quotes the estimate of the inquisitor Sprenger, joint author of the "Witch Hammer," that during the Christian period some 9,000,000 persons, mostly women, were burned as witches. (3I.) Seven thousand victims are said to have been burned at Treves, 600 by a single bishop of Bamburg, 800 in a single year in the bishopric of Wurtzburg. At Toulouse 400 persons perished at a single burning. (29: ch. I.) (20: V. I. ch. I.) One witch judge boasted that he executed 900 witches in fifteen years. The last mass burning in Germany was said to have taken place in I678, when 97 persons were burned together. The earliest recorded burning of a witch in England is in Walter Mapes' De Nugis Curialium, in the reign of Henry II. An old black letter tract gloats over the execution at Northampton, I6I2, of a number of persons convicted of witchcraft. (32.) The last judicial sentence 
was in 1736 , when one Jane Wenham was found guilty of conversing familiarly with the devil in the form of a cat. (33.)

The connection between the witchcraft delusion and the attitude toward all women has already been implied. (34.) The dualistic teaching of the early church fathers, with its severance of matter and spirit and its insistence on the ascetic ideal of life, had focussed on sexuality as the outstanding manifestation of fleshly desires. The contact of the sexes came to be looked upon as the supreme sin. Celibacy taught that through the observance of the taboo on woman the man of God was to be saved from pollution. Woman was the arch temptress who by the natural forces of sex attraction, reinforced by her evil charms and incantations, made it so difficult to attain the celibate ideal. From her ancestress Eve woman was believed to inherit the natural propensity to lure man to his undoing. Thus the old belief in the uncleanness of woman was renewed in the minds of men with even greater intensity than ever before, and in addition to a dangerous adventure, even within the sanction of wedlock the sex act became a deed of shame. The following quotations from the church fathers will illustrate this view :

Jerome said, " Marriage is always a vice ; all we can do is to excuse and cleanse it. ... In 
Paradise Eve was a virgin. Virginity is natural while wedlock only follows guilt." (35.)

Tertullian addressed women in these words: "Do you not know that you are each an Eve? The sentence of God on this sex of yours lives in this age. ... You are the devil's gateway. ... You destroy God's image, Man." (35:

Bk. I.)

Thus woman became degraded beyond all previous thought in the teaching of the early church. The child was looked upon as the result of an act of sin, and came into the world tainted through its mother with sin. At best marriage was a vice. All the church could do was to cleanse it as much as possible by sacred rites, an attempt which harked back to the origin of marriage as the ceremonial breaking of taboo. Peter Lombard's Sentences affirmed marriage a sacrament. This was reaffirmed at Florence in I439. In I565, the Council of Trent made the final declaration. But not even this could wholly purify woman, and intercourse with her was still regarded as a necessary evil, a concession that had to be unwillingly made to the lusts of the flesh.

Such accounts as we have of the lives of holy women indicate that they shared in the beliefs of their times. In the account of the life of a saint known as the Blessed Eugenia preserved in an old palimpsest (36) we read that she 
adopted the costume of a monk,- "Being a woman by nature in order that I might gain everlasting life." The same account tells of another holy woman who passed as a eunuch, because she had been warned that it was easier for the devil to tempt a woman. In another collection of lives of saints is the story (37) of a holy woman who never allowed herself to see the face of a man, even that of her own brother, lest through her he might go in among women. Another holy virgin shut herself up in a tomb because she did not wish to cause the spiritual downfall of a young man who loved her.

This long period of religious hatred of and contempt for woman included the Crusades, the Age of Chivalry (38), and lasted well into the Renaissance. (39.) Students of the first thousand years of the Christian era like Donaldson (22), McCabe (40), and Benecke argue that the social and intellectual position of women was probably lower than at any time since the creation of the world. It was while the position of woman as wife and mother was thus descending into the slough which has been termed the Dark Age of Woman that the Apotheosis of the Blessed Virgin was accomplished. The attitude toward human love, generation, the relation of the earthly mother to the human child because of Eve's sin, all made the Immacu- 
late Conception a logical necessity. The doctrine of the virgin birth disposed of sin through the paternal line. But if Mary was conceived in sin or was not purified from sin, even that of the first parent, how could she conceive in her body him who was without sin? The controversy over the Immaculate Conception which began as early as the seventh century lasted until Pius IX declared it to be an article of Catholic belief in I854. Thus not only Christ, but also his mother became purged of the sin of conception by natural biological processes, and the same immaculacy and freedom from contamination was accorded to both. In this way the final step in the differentiation between earthly motherhood and divine motherhood was completed.

The worship of the virgin by men and women who looked upon the celibate life as the perfect life, and upon the relationship of earthly fatherhood and motherhood as contaminating, gave the world an ideal of woman as "superhuman, immaculate, bowing in frightened awe before the angel with the lily, standing mute and with downcast eyes before her Divine Son." (4I.) With all its admitted beauty, this ideal represented not the institution of the family, but the institution of the church. Chivalry carried over from the church to the castle this concept of womanhood and set it to 
the shaping of The Lady (42), who was finally given a rank in the ideals of knighthood only a little below that to which Mary had been elevated by the ecclesiastical authorities. This concept of the lady was the result of the necessity for a new social standardization which must combine beauty, purity, meekness and angelic goodness. Only by such a combination could religion and family life be finally reconciled. By such a combination, earthly motherhood could be made to approximate the divine motherhood.

With the decline of the influence of chivalry, probably as the result of industrial changes, The Lady was replaced by a feminine ideal which may well be termed the " Model Woman." Although less ethereal than her predecessor, The Lady, the Model Woman is quite as much an attempt to reconcile the dualistic attitude, with its Divine Mother cult on the one hand, and its belief in the essential evil of the procreative process and the uncleanness of woman on the other, to human needs. The characteristics of the Model Woman must approximate those of the Holy Virgin as closely as possible. Her chastity before marriage is imperative. Her calling must be the high art of motherhood. She must be the incarnation of the maternal spirit of womanhood, but her purity must remain unsullied by any trace of erotic passion. 


\section{TABOO AND GENETICS}

A voluminous literature which stated the virtues and duties of the Model Woman blossomed out in the latter part of the eighteenth and first half of the nineteenth century. (43.) The Puritan ideals also embodied this concept. It was by this attempt to make woman conform to a standardized ideal that man sought to solve the conflict between his natural human instincts and desires and the early Christian teaching concerning the sex life and womanhood.

\section{BIBLIOGRAPHY FOR CHAPTER II}

I. Frazer, J. G. The Golden Bough. A Study in Magic and Religion. Part I. The Magic Art. 2 vols. Macmillan. London, I9II. Part V. Spirits of the Corn and of the Wild. 2 vols. London, Igr2.

2. Farnell, L. R. Evolution of Religion. 235 pp.

Williams and Norgate. London, 1905. Crown Theological Library, Vol I2.

3. Frazer, J. G. Part IV. of The Golden Bough ; Adonis, Attis, and Osiris. Chaps. III and IV. Macmillan. London, 1907.

- Sumner, W. G. Folkways. 692 pp. Ginn \& Co. Boston, I907. Chap. XVI, Sacral Harlotry.

- Lombroso, Cesare, and Lombroso-Ferrero, G. La donna delinquente. 508 pp. Fratelli Bocca. Milano, I9I5.

4. Farnell, L. R. Sociological Hypotheses Concerning the Position of Woman in Ancient Religion. Archiv für Religionswissenschaft. Siebenter Band, I904.

5. Fowler, W. Warde. The Religious Experiences of the Roman People. 504 pp. Macmillan. London, I9II. 6. For a description of these sibyls with a list of the works in which they are mentioned, see : 


\section{TABOO AND GENETICS}

- Fullom, Steven Watson. The History of Woman. Third Ed. London, I855.

- Rohmer, Sax. (Ward, A. S.) The Romance of Sorcery. 320 pp. E. P. Dutton \& Co., New York, I9I4.

7. Maury, L. F. La Magie et L'Astrologie dans l'Antiquité et au Moyen Age. Quatrieme éd. 484 pp. Paris, 1877 .

8. Lombroso, Cesare. Priests and Women's Clothes. North American Review. Vol. I92, rgro.

9. For an extensive compilation of facts from ancient literature and history concerning sacred women, see : Alexander, W. History of Women from the Earliest Antiquity to the Present Time. 2 vols. W. Strahan. London, I779.

Io. Mason, Otis T. Woman's Share in Primitive Culture. 295 pp. Appleton. New York, I894.

- Dycr, T. F. S. Plants in Witchcraft. Popular Science Monthly. Vol. 34, I889, pp. 826-833.

- Donaldson, Rev. James. Woman, Her Position and Influence in Ancient Greece and Rome. $278 \mathrm{pp}$. Longmans, Green. London, 1907.

II. Spencer, Herbert. Study of Sociology. 43 I pp. Appleton. N. Y., I880.

I2. Schirmacher, Käthe. Das Rătsel: Weib. I6o pp. A Duncker. Weimar, IgII.

13. Ward, Lester F. Psychic Factors in Civilization. 369 pp. Ginn \& Co., Boston and New York, rgo6. Chap. XXVI.

- Pure Sociology. 607 pp. Macmillan. N. Y., I903. I4. Schreiner, Olive. Woman and Labour. 299 pp. Frederick A. Stokes Co. N. Y., IgII.

I5. Hall, G. Stanley. Adolescence. 2 vols. Appleton. N. Y., I904.

--Dupouy, Edmund. Psychologie morbide. Librairie des Sciences Psychiques, I907.

I6. The Ante-Nicene Fathers. Translation by the Rev. Alexander Roberts and James Donaldson, LL.D., 
and others. American Reprint of the Edinburgh Edition. Buffalo, I889.

I7. Hatch, Edwin. Influence of Greek Ideas and Usages upon the Christian Church. Ed. by A. M. Fairbairn. 4th ed. London, I892. Hibbert Lectures, I888.

I8. Gilbert, George Holley. The Greek Strain in Our Oldest Gospels. North American Review. Vol. 192, IgIo.

Ig. Hirn, Yrjo. The Sacred Shrine. 574 pp. Macmillan. London, I9I2.

20. Lecky, W. E. H. Rationalism in Europe. 2 vols. Appleton. N. Y. and London, I9IO. Vol. II, pp. $220 \mathrm{f}$.

21. Wright, Thomas. Narratives of Sorcery and Magic. 2 vols. R. Bentley. London, I85I.

22. Donaldson, Rev. James. The Position of Woman Among the Early Christians. Contemporary Review. Vol. 56, I889.

23. Bingham, Joseph. Antiquities of the Christian Church. 2 vols. London, 1846 .

24. Sumner, W. G. Witchcraft. Forum. Vol. 4I, I909, pp. 4 10-423.

25. Gaster, M. Two Thousand Years of a Charm Against the Child-stealing Witch. Folklore. Vol. XI, No. 2, June, rgoo.

26. For discussion of the dates of the Church Councils see Rev. Charles J. Hefele, Councils of the Church. Trans. fr. the German by C. W. Bush, I883.

27. Alice Kyteler. A contemporary narrative of the Proceedings against Dame Alice Kyteler, prosecuted for sorcery by Richard de Ledrede, Bishop of Ossory, I324. Edited by Thomas Wright. London, I843. 28. Burr, George L. The Literature of Witchcraft. Papers of the American Historical Association. Vol IV, pp. 37-66. G. P. Putnam's Sons. N. Y., I8go.

29. Michelet, J. La Sorcière. 488 pp. Paris, I878. Trans. of Introduction by L. J. Trotter. 
30. Scherr, Johannes. Deutsche Frauenwelt. Band II.

3I. Avebury, Right Hon. Lord (Sir John Iubbock). Marriage, Totemism and Religion. 243 pp. Longmans, Green. London, I9II. Footnote, p. I27.

32. Wood, Wm. Witchcraft. Cornhill Magazine. Vol. V, I 898 .

- Lea, H. C. Superstition and Force. 407 pp. Philadelphia, I866.

33. Bragge, F. Jane Wenham. 36 pp. E. Curll. London I7 2 .

34. Paulus, Nikolaus. Die Rolle der Frau in der Geschichte des Hexenwahns. Historisches Jahrbuch. XXIX Band. München. Jahrgang Igr8.

35. Select Library of Nicene and Post-Nicene Fathers of the Christian Church. 2d. series. Vol. 6, Letter xxii, Ad Eustachium.

36. Studia Sinaitica No. IX. Select Narratives of Holy Women from the Syro-Antiochene or Sinai Palimpsest as written above the old Syriac Gospels by John the Stylite, of Beth-Mari Ianun in A.D. 778 . Edited by Agnes Smith Lewis, M.R.A.S. London, Ig0o.

37. Lady Meux Mss. No. VI. British Museum. The Book of Paradise, being the Histories and Sayings of the Monks and Ascetics of the Egyptian Desert by Palladius, Hieronymus and others. English Trans. by E. A. Wallis Budge. (From the Syriac.) Vol. I.

38. Gautier, Emile Théodore Léon. La Chevalerie. $850 \mathrm{pp}$. C. Delagrave. Paris, I8go.

39. Maulde la Clavière, R. de. The Women of the Renaissance. Trans. by G. H. Ely. 5Io pp. Swan Sonnenschein, Igoo.

40. McCabe, Joseph. Woman in Political Evolution. Watts \& Co. London, Igog.

4I. Barnes, Earl. Woman in Modern Society. 257 pp. B. W. Huebsch. N. Y., IgI3. 


\section{TABOO AND GENETICS}

42. Putnam, Emily James. The Lady. 323 pp. Sturgis \& Walton Co. N. Y., I9ro.

43. Excellent examples of this literature are Kenrick's "Tho Whole Duty of a Woman, or A Guide to the Female Sex," published some time in the eighteenth century (a copy in the Galatea Collection, Boston Public Library); and Duties of Young Women, by E. H. Chapin. 2 I 8 pp. G. W. Briggs. Boston, I848. 


\section{CHAPTER III}

THE DUALISM IN MODERN LIFE: THE INSTITUTIONAL TABOO

The taboo and modern institutions; Survival of ideas of the uncleanness of woman; Taboo and the family; The "good" woman; The "bad "woman; Increase in the number of women who do not fit into the ancient classifications.

With the gradual accumulation of scientific knowledge and increasing tendency of mankind toward a rationalistic view of most things, it might be expected that the ancient attitude toward sex and womanhood would have been replaced by a saner feeling. To some extent this has indeed been the case. It is surprising, however, to note the traces which the old taboos and superstitions have left upon our twentieth century social life. Men and women are becoming conscious that they live in a world formed out of the worlds that have passed away. The underlying principle of this social phenomenon has been called the principle of " the persistence of institutions." (I). Institutionalized habits, mosaics of reactions to forgotten situations, fall like shadows on the life of to-day. Memories 


\section{TABOO AND GENETICS}

of the woman shunned, of the remote woman goddess, and of the witch, transmit the ancient forms by which woman has been expected to shape her life.

It may seem a far cry from the savage taboo to the institutional life of the present; but the patterns of our social life, like the infantile patterns on which adult life shapes itself, go back to an immemorial past. Back in the early life of the peoples from which we spring is the taboo, and in our own life there are customs so analogous to many of these ancient prohibitions that they must be accounted survivals of old social habits just as the vestigial structures within our bodies are the remnants of our biological past.

The modern preaching concerning woman's sphere, for example, is an obvious descendant of the old taboos which enforced the division of labour between the sexes. Just as it formerly was death for a woman to approach her husband's weapons, so it has for a long time been considered a disgrace for her to attempt to compete with man in his line of work. Only under the pressure of modern industrialism and economic necessity has this ancient taboo been broken down, and even now there is some reluctance to recognize its passing. The exigencies of the world war have probably done more than any other one thing to accelerate the dis- 


\section{I78 TABOO AND GENETICS}

appearance of this taboo on woman from the society of to-day.

A modern institution reminiscent of the men's house of the savage races, where no woman might intrude, is the men's club. This institution, as Mr Webster has pointed out (2), is a potent force for sexual solidarity and consciousness of kind. The separate living and lack of club activity of women has had much to do with a delay in the development of a sex consciousness and loyalty. The development of women's organizations along the lines of the men's clubs has been a powerful factor in enabling them to overcome the force of the taboos which have lingered on in social life. Only through united resistance could woman ever hope to break down the barriers with which she was shut off from the fullness of life.

Perhaps the property taboo has been as persistent as any other of the restrictions which have continued to surround woman through the ages. Before marriage, the girl who is "well brought up" is still carefully protected from contact with any male. The modern system of chaperonage is the substitute for the old seclusion and isolation of the pubescent girl. Even science was influenced by the old sympathetic magic view that woman could be contaminated by the touch of any other man than her husband, for the principle of telegony, 
that the father of one child could pass on his characteristics to offspring by other fathers, lingered in biological teaching until the very recent discoveries of the physical basis of heredity in the chromosomes. Law-making was also influenced by the idea of woman as property. For a long time there was a hesitancy to prohibit wife-beating on account of the feeling that the wife was the husband's possession, to be dealt with as he desired. The laws of coverture also perpetuated the old property taboos, and gave to the husband the right to dispose of his wife's property.

The general attitude towards such sexual crises as menstruation and pregnancy is still strongly reminiscent of the primitive belief that woman is unclean at those times. Mothers still hesitate to enlighten their daughters concerning these natural biological functions, and as a result girls are unconsciously imbued with a feeling of shame concerning them. Modern psychology has given many instances of the rebellion of girls at the inception of menstruation, for which they have been ill prepared. There is little doubt that this attitude has wrought untold harm in the case of nervous and delicately balanced temperaments, and has even been one of the predisposing factors of neurosis. (3).

The old seclusion and avoidance of the pregnant woman still persists. The embarrass- 
ment of any public appearance when pregnancy is evident, the jokes and secrecy which surround this event, show how far we are from rationalizing this function.

Even medical men show the influence of old superstitions when they refuse to alleviate the pains of childbirth on the grounds that they are good for the mother. Authorities say that instruction in obstetrics is sadly neglected. A recent United States report tells us that preventable diseases of childbirth and pregnancy cause more deaths among women than any other disease except tuberculosis. (4).

The belief in the possession by woman of an uncanny psychic power which made her the priestess and witch of other days, has crystallized into the modern concept of womanly intuition. In our times, women " get hunches," have "feelings in their bones," etc., about people, or about things which are going to happen. They are often asked to decide on business ventures or to pass opinions on persons whom they do not know. There are shrewd business men who never enter into a serious negotiation without getting their wives' intuitive opinion of the men with whom they are dealing. The psychology of behaviour would explain these rapid fire judgments of women as having basis in observation of unconscious movements, while another psychological ex- 
planation would emphasize sensitiveness to suggestion as a factor in the process. Yet in spite of these rational explanations of woman's swift conclusions on matters of importance, she is still accredited with a mysterious faculty of intuition.

A curious instance of the peculiar forms in which old taboos linger on in modern life is the taboos on certain words and on discussion of certain subjects. The ascetic idea of the uncleanness of the sex relation is especially noticeable. A study of 150 girls made by the writer in I9I6-I7 showed a taboo on thought and discussion among well-bred girls of the following subjects, which they characterize as " indelicate," " polluting," and "things completely outside the knowledge of a lady."

I. Things contrary to custom, often called " wicked" and "immoral."

2. Things " disgusting," such as bodily functions, normal as well as pathological, and all the implications of uncleanliness.

3. Things uncanny, that " make your flesh creep," and things suspicious.

4. Many forms of animal life which it is a commonplace that girls will fear or which are considered unclean.

5. Sex differences.

6. Age differences. 
7. All matters relating to the double standard of morality.

8. All matters connected with marriage, pregnancy, and childbirth.

9. Allusions to any part of the body except head and hands.

Io. Politics.

II. Religion.

It will be noted that most of these taboo objects are obviously those which the concept of the Model Woman has ruled out of the life of the feminine half of the world.

As might well be expected, it is in the marriage ceremony and the customs of the family institution that the most direct continuation of taboo may be found. The early ceremonials connected with marriage, as $\mathrm{Mr}$ Crawley has shown, counteracted to some extent man's ancient fear of woman as the embodiment of a weakness which would emasculate him. Marriage acted as a bridge, by which the breach of taboo was expiated, condoned, and socially countenanced. Modern convention in many forms perpetuates this concept. Marriage, a conventionalized breach of taboo, is the beginning of a new family. In all its forms, social, religious, or legal, it is an accepted exception to the social injunctions which keep men and women apart under other circumstances.

The new family as a part of the social order 


\section{TABOO AND GENETICS}

comes into existence through the social recognition of a relationship which is considered especially dangerous and can only be recognized by the performance of elaborate rites and ceremonies. It is taboo for men and women to have contact with each other. Contact may occur only under ceremonial conditions, guarded in turn by taboo, and therefore socially recognized. The girl whose life from puberty on has been carefully guarded by taboos, passes through the gateway of ceremonial into a new life, which is quite as carefully guarded. These restrictions and elaborate rituals which surround marriage and family life may appropriately be termed institutional taboos. They include the property and division of labour taboos in the survival forms already mentioned, as well as other religious and social restrictions and prohibitions.

The foundations of family life go far back of the changes of recent centuries. The family has its source in the mating instinct, but this instinct is combined with other individual instincts and social relationships which become highly elaborated in the course of social evolution. The household becomes a complex economic institution. While the processes of change may have touched the surface of these relations, the family itself has remained to the present an institution established through the social sanctions of communities more primi- 
tive than our own. The new family begins with the ceremonial breach of taboo,-the taboo which enjoins the shunning of woman as a being both sacred and unclean. Once married, the woman falls under the property taboo, and is as restricted as ever she was before marriage, although perhaps in slightly different ways. In ancient Rome, the wife was not mistress of the hearth. She did not represent the ancestral gods, the lares and penates, since she was not descended from them. In death as in life she counted only as a part of her husband. Greek, Roman and Hindu law, all derived from ancestor worship, agreed in considering the wife a minor. (5).

These practices are of the greatest significance in a consideration of the modern institutional taboos which surround the family. Students agree that our own mores are in large part derived from those of the lowest class of freedmen in Rome at the time when Christianity took over the control which had fallen from the hands of the Roman emperors. These mores were inherited by the Bourgeoisie of the Middle Ages, and were passed on by them as they acquired economic supremacy. Thus these practices have come down to us unchanged in spirit even if somewhat modified in form, to fit the changed environment of our times.

The standardization of the family with its 
foundations embedded in a series of institutional taboos, added its weight to the formulation of the Model Woman type referred to at the close of the preceding chapter. The model wife appears in the earliest literature. In The Trojan Women, Hecuba tells how she behaved in wedlock. She stayed at home and did not gossip. She was modest and silent before her husband. The patient Penelope was another ideal wife. To her, her son Telemachus says:

"Your widowed hours apart, with female toil, And various labours of the loom, beguile, There rule, from palace cares remote and free, That care to man belongs, and most to me."

The wifely type of the Hebrews is set forth in Proverbs xxxi, I0-3r. Her virtues consisted in rising while it was yet night, and not eating the bread of idleness. In her relation to her husband, she must never surprise him by unusual conduct, and must see that he was well fed.

The Romans, Hindus, and Mohammedans demanded similar virtues in their wives and mothers. The wives of the medieval period were to remain little girls, most admired for their passive obedience. Gautier puts into the mouth of a dutiful wife of the Age of Chivalry the following soliloquy:

"I will love no one but my husband. Even 
if he loves me no longer, I will love him always. I will be humble and as a servitor. I will call him my sire, or my baron, or domine. . ." (6).

The modern feminine ideal combines the traits demanded by the worship of the madonna and the virtues imposed by the institutional taboos which surround the family. She is the virgin pure and undefiled before marriage. She is the protecting mother and the obedient, faithful wife afterward. In spite of various disrupting influences which are tending to break down this concept, and which will presently be discussed, this is still the ideal which governs the life of womankind. The average mother educates her daughter to conform to this ideal woman type which is the synthesized product of ages of taboo and religious mysticism. Home training and social pressure unite to force woman into the mould wrought out in the ages when she has been the object of superstitious fear to man and also a part of his property to utilize as he willed. Being thus the product of wholly irrational forces, it is little wonder that only in recent years has she had any opportunity to show what she in her inmost soul desired, and what capabilities were latent within her personality.

In sharp contrast to the woman who conforms to the standards thus created for her, is the prostitute, who is the product of forces as 


\section{TABOO AND GENETICS}

ancient as those which have shaped the family institution. In the struggle between man's instinctive needs and his mystical ideal of womanhood, there has come about a division of women into two classes.- the good and the bad. It is a demarcation as sharp as that involved in the primitive taboos which set women apart as sacred or unclean. In building up the Madonna concept and requiring the women of his family to approximate this mother-goddess ideal, man made them into beings too spiritual to satisfy his earthly needs. The wife and mother must be pure, as he conceived purity, else she could not be respected. The religious forces which had set up the worship of maternity had condemned the sex relationship and caused a dissociation of two elements of human nature which normally are in complete and intimate harmony. One result of this divorce of two biologically concomitant functions was the institution of prostitution.

Prostitution is designed to furnish and regulate a supply of women outside the mores of the family whose sex shall be for sale, not for purposes of procreation but for purposes of indulgence. In the ancient world, temple prostitution was common, the proceeds going to the god or goddess; but the sense of pollution in the sex relation which came to be so potent an element in the control of family life drove the 
prostitute from the sanctuary to the stews and the brothel, where she lives to-day. She has become the woman shunned, while the wife and mother who is the centre of the family with its institutional taboos is the sacred woman, loved and revered by men who condemn the prostitute for the very act for which they seek her company. Such is the irrational situation which has'come to us as a heritage from the past.

Among the chief causes which have impelled women into prostitution rather than into family life are the following: (I) Slavery ; (2) poverty ; (3) inclination. These causes have been expanded and re-grouped by specialists, but the only addition which the writer sees as necessary in consequence of the study of taboo is the fact that the way of the woman transgressor is peculiarly hard because of the sex taboo, the ignorance and narrowness of good women, and the economic limitations of all women. Ignorance of the results of entrance into a life which usually means abandonment of hope may be a contributing cause. Boredom with the narrowness of family life and desire for adventure are also influences.

That sex desire leads directly to the life of the prostitute is unlikely. The strongly sexed class comes into prostitution by the war of irregular relationships with men to whom they have been attached, and who have abandoned them 
or sold them out. Many authorities agree on the frigidity of the prostitute. It is her protection from physical and emotional exhaustion. This becomes evident when it is learned that these women will receive thirty men a day, sometimes more. A certain original lack of sensitiveness may be assumed, especially since the investigations of prostitutes have shown a large proportion, perhaps one-third, who are mentally inferior. It is an interesting fact that those who are sensitive to their social isolation defend themselves by dwelling on their social necessity. Either intuitively or by a trade tradition, the prostitute feels that " she remains, while creeds and civilizations rise and fall, blasted for the sins of the people." A beautiful young prostitute who had been expelled from a high grade house after the exposures of the Lexow Investigation, once said to the writer : "It would never do for good women to know what beasts men are. We girls have got to pay."

The lady, dwelling on her pedestal of isolation, from which she commands the veneration of the chivalrous gentleman and the adoration of the poet, is the product of a leisure assured by property. At the end of the social scale is the girl who wants to be a lady, who doesn't want to work, and who, like the lady, has nothing to sell but herself. The life of the prostitute is the nearest approach for the poor 


\section{TABOO AND GENETICS}

girl to the life of a lady with its leisure, its fine clothes, and its excitement. So long as we have a sex ethics into which are incorporated the taboo concepts, the lady cannot exist without the prostitute. The restrictions which surround the lady guard her from the passions of men. The prostitute has been developed to satisfy masculine needs which it is not permitted the lady to know exist.

But in addition to the married woman who has fulfilled the destiny for which she has been prepared and the prostitute who is regarded as a social leper, there is a large and increasing number of unmarried women who fall into neither of these classes. For a long time these unfortunates were forced to take refuge in the homes of their luckier sisters who had fulfilled their mission in life by marrying, or to adopt the life of the religieuse. Economic changes have brought an alteration in their status, however, and the work of the unattached woman is bringing her a respect in the modern industrial world that the "old maid" of the past could never hope to receive.

Although at first often looked upon askance, the working woman by the sheer force of her labours has finally won for herself a recognized place in society. This was the first influence that worked against the old taboos, and made possible the tentative gropings toward a new 
standardization of women. The sheer weight of the number of unattached women in present day life has made such a move a necessity. In England, at the outbreak of the war, there were $1,200,000$ more women than men. It is estimated that at the end of the war at least $25 \%$ of English women are doomed to celibacy and childlessness. In Germany, the industrial census of 1907 showed that only $9 \frac{1}{2}$ millions of women were married, or about one-half the total number over eighteen years of age. In the United States, married women constitute less than $60 \%$ of the women fifteen years of age and over.

The impossibility of a social system based on the old sex taboos under the new conditions is obvious. There must be a revaluation of woman on the basis of her mental and economic capacity instead of on the manner in which she fits into a system of institutional taboos. But the old concepts are still with us, and have shaped the early lives of working women as well as the lives of those who have fitted into the old grooves. Tenacious survivals surround them both, and are responsible for many of the difficulties of mental and moral adjustment which make the woman question a puzzle to both conservative and radical thinkers on the subject. 


\section{BIBLIOGRAPHY FOR CHAPTER III}

r. Davis, Michael M. Psychological Interpretations of

Society. $260 \mathrm{pp}$. Columbia University. Longmans.

Green \& Co. N. Y., I909.

2. Webster, Hutton. Primitive Secret Societies. 227 pp.

Macmillan. N. Y., Igo8.

3. Blanchard, Phyllis. The Adolescent Girl. 242 pp.

Kegan Paul \& Co., London, I92I.

- Peters, Iva L. A Questionnaire Study of Some of the

Effects of Social Restrictions on the American

Girl. Pedagogical Seminary, December, rgr6,

Vol. XXIII, pp. 550-569.

4. Report of the U. S. Children's Bureau, rgr7.

5. Fowler, W. Warde. The Religious Experience of the

Roman People. 504 pp. Macmillan. London, IgIr.

- Fustel de Coulanges, Numa Denis. The Ancient City.

Trans. from the latest French edition by Willard

Small. Ioth ed. Lee and Shepard. Boston, rgor. $529 \mathrm{pp}$.

6. Gautier, Emile Théodore Léon. La Chevalerie. 850 pp.

C. Delagrave. Paris, $\mathbf{x} 890$. 


\section{CHAPTER IV}

DYSGENIC INFLUENCES OF THE INSTITUTIONAL TABOO

Taboo survivals act dysgenically within the family under present conditions; Conventional education of girls a dysgenic influence; Prostitution and the family; Influence of ancient standards of "good " and "bad." The illegitimate child; Effect of fear, anger, etc., on posterity; The attitude of economically independent women toward marriage.

It is evident that in the working of old taboos as they have been preserved in our social institutions there are certain dysgenic influences which may well be briefly enumerated. For surely the test of the family institution is the way in which it fosters the production and development of the coming generation. The studies made by the Galton Laboratory in England and by the Children's Bureau in Washington combine with our modern knowledge of heredity to show that it is possible to cut down the potential heritage of children by bad matrimonial choices. If we are to reach a solution of these population problems, we must learn to approach the problem of the sex relation without that sense of uncleanness which has led so 
many generations to regard marriage as giving respectability to an otherwise wicked inclination. The task of devising a sane approach is only just begun. But the menace of prostitution and of the social diseases has become so great that society is compelled from an instinct of sheer self-preservation to drag into the open some of the iniquities which have hitherto existed under cover.

In the first place, the education of girls, which has been almost entirely determined by the standardized concepts of the ideal woman, has left them totally unprepared for wifehood and motherhood, the very calling which those ideals demand that they shall follow. The whole education of the girl aims at the concealment of the physiological nature of men and women. She enters marriage unprepared for the realities of conjugal life, and hence incapable of understanding either herself or her husband. When pregnancy comes to such a wife, the old seclusion taboos fall upon her like a categorical imperative. She is overwhelmed with embarrassment at a normal and natural biological process which can hardly be classified as "romantic." Such an attitude is neither conducive to the eugenic choice of a male nor to the proper care of the child either before or after its birth.

A second dysgenic influence which results 
from the taboo system of sexual ethics is the institution of prostitution, the great agency for the spread of venereal disease through the homes of the community, and which takes such heavy toll from the next generation in lowered vitality and defective organization.

The IgII report of the Committee on the Social Evil in Baltimore showed that at the time there was in that city one prostitute to every 500 inhabitants. As is the case everywhere, such statistics cover only prostitutes who have been detected. Hospital and clinic reports for Baltimore gave 9,450 acute cases of venereal disease in Igo6 as compared with 575 cases of measles, I,I72 cases of diphtheria, 577 of scarlet fever, I75 of chickenpox, 58 of smallpox and 733 cases of tuberculosis.

Statistics on the health of young men shown by the physical examinations of the various draft boards throughout the country give us a more complete estimate of the prevalence of venereal disease among the prospective fathers of the next generation than any other figures for the United States. In an article in the New York Medical Journal for February 2, I9I8, Dr. Isaac W. Brewer of the Medical Reserve Corps presents tables showing the percentage of rejections for various disabilities among the applicants for enlistment in the regular army from January I, I9I2, to December 
3I, I9I5. Among I53,705 white and II,092 coloured applicants, the rejection rate per $I, 000$ for venereal disease was 196.7 for whites and 279.9 for coloured as against 9I.3 for whites and 75.0 for coloured for heart difficulties, next on the list. In foreshadowing the results under the draft, Dr. Brewer says: "Venereal disease is the greatest cause for rejection, and reports from the cantonments where the National Army has assembled indicate that a large number of the men had these diseases when they arrived at the camp. It is probably true that venereal diseases cause the greatest amount of sickness in our country.'

Statistics available for conditions among the American Expeditionary Forces must be treated with great caution. Detection of these diseases at certain stages is extremely difficult. Because of the courtesy extended to our men by our allies, cases were treated in French and English hospitals of which no record is available. But it is fairly safe to say that there was no such prevalence of disease as was shown by the Exner Report to have existed on the Mexican Border. It may even be predicted that the education in hygienic measures which the men received may in time affect favourably the health of the male population and through them their wives and children. But all who came in contact with this problem in the army know that it 


\section{TABOO AND GENETICS}

is a long way to the understanding of the difficulties involved before we approach a solution. We do know, on the basis of the work, of Neisser, Lesser, Forel, Flexner and others, that regulation and supervision seem to increase the incidence of disease. Among the reasons for this are: (I) difficulties of diagnosis; difficulties attendant on the apprehension and examination of prostitutes; (3) the infrequency of examination as compared with the number of clients of these women; and perhaps as important as any of these reasons is the false sense of security involved.

The model woman of the past has known very little of the prostitute and venereal disease. It is often stated that her moral safety has been maintained at the expense of her fallen and unclean sister. But such statements are not limited as they should be by the qualification that her moral safety obtained in such a fashion is often at the expense of her physical safety. If the assumption has a basis in fact that there is a relation between prostitution and monogamic marriage, the complexity of the problem becomes evident. It is further complicated by the postponement of marriage from economic reasons, hesitation at the assumption of family responsibilities at a time of life when ambition as well as passion is strong, when the physiological functions are stimulated by city life 
and there is constant opportunity for relief of repression for a price. It is here that the demarcation between the man's and the woman's world shows most clearly. It may well be that the only solution of this problem is through the admission of a new factor-the "good" woman whom taboo has kept in ignorance of a problem that is her own. If it be true that the only solution for the double standard whose evils show most plainly here is a new single standard which has not yet been found, then it is high time that we find what that standard is to be, for the sake of the future.

The third dysgenic influence which works under cover of the institutional taboo is akin to the first in its ancient standards of "good" and "bad." We are only recently getting any standards for a good mother except a man's choice and a wedding ring. Men's ideals of attractiveness greatly complicate the eugenic situation. A good matchmaker, with social backing and money, can make a moron more attractive than a pushing, energetic girl with plenty of initiative, whose contribution to her children would be equal or superior to that of her mate. A timid, gentle, pretty moron, with the attainment of a girl of twelve years, will make an excellent match, and bring into the world children who give us one of the reasons why it is "three generations from shirt-sleeves 
to shirt-sleeves." For such a girl, the slave to convention, exactly fits the feminine ideal which man has built up for himself. And she will be a good wife and mother in the conventional sense all her life. This following of an ideal feminine type conceived in irrational processes in former days inclines men to marry women with inferior genetic possibilities because they meet the more insistent surface requirements. The heritage of our children is thus cut down, and many a potential mother of great men remains unwed.

The same survival of ancient sex taboos is seen in the attitude toward the illegitimate child. The marriage ceremony is by its origin and by the forms of its perpetuation the only sanction for the breaking of the taboo on contact between men and women. The illegitimate child, the visible symbol of the sin of its parents, is the one on whom most heavily falls the burden of the crime. Society has for the most part been utterly indifferent to the eugenic value of the child and has concerned itself chiefly with the manner of its birth. Only the situation arising out of the war and the need of the nations for men has been able to partially remedy this situation.

The taboos on illegitimacy in the United States have been less affected by the practical population problems growing out of war con- 
ditions than those of other countries. As compared with the advanced stands of the Scandinavian countries, the few laws of progressive states look painfully inadequate. Miss Breckinridge writes (I) :

"The humiliating and despised position of the illegitimate child need hardly be pointed out. He was the son of nobody, filius nullius, without name or kin so far as kinship meant rights of inheritance or of succession. In reality this child of nobody did in a way belong to his mother as the legitimate child never did in common law, for, while the right of the unmarried mother to the custody of the child of her shame was not so noble and dignified a thing as the right of the father to the legitimate child, she had in fact a claim, at least so long as the child was of tender years, not'so different from his and as wide as the sky from the impotence of the married mother. The contribution of the father has been secured under conditions shockingly humiliating to her, in amounts totally inadequate to her and the child's support. In Illinois, $\$ 550$ over 5 years; Tennessee, $\$ 40$ the first year, $\$ 30$ the second, $\$ 20$ the third. (See studies of the Boston Conference on Illegitimacy, September, I9I4, p. 47.) Moreover, the situation was so desperate that physicians, social workers and relatives have conspired to save the girl's respectability at the risk of the child's life and at the cost of all spiritual and educative value of the experience of motherhood. This has meant a greatly higher death rate among illegitimate infants, a higher crime and a higher dependency rate."

The fifth of the dysgenic influences which 


\section{TABOO AND GENETICS}

has been fostered by the institutional taboo is uncovered by recent studies of the effect of certain emotions on the human organism. The life of woman has long been shadowed by the fact that she has been the weaker sex; that even when strong she has been weighted by her child; and that throughout the period of private property she has been the poor sex, dependent on some male for her support. In an age of force, fear has been her strong emotion. If she felt rage it must be suppressed. Disappointment and discouragement had also to be borne in silence and with patience. Of such a situation Davies says:

"The power of the mind over the body is a scientific fact, as is evidenced by hypnotic suggestion and in the emotional control over the chemistry of health through the agency of the internal secretions. The reproductive processes are very susceptible to chemic influences. Thus the influences of the environment may in some degree carry through to the offspring." (2.)

The studies of Drs Crile and Cannon show that the effects of fear on the ganglionic cells are tremendous. Some of the cells are exhausted and completely destroyed by intensity and duration of emotion. Cannon's experiments on animals during fear, rage, anger, and hunger, show that the entire nervous system is involved and that internal and external functions change 
their normal nature and activity. The thyroid and adrenal glands are deeply affected. In times of intense emotion, the thyroid gland throws into the system products which cause a quickened pulse, rapid respiration, trembling, arrest of digestion, etc. When the subjects of experiments in the effect of the emotions of fear, rage, etc., are examined, it is found that the physical development, especially the sexual development, is retarded. Heredity, age, sex, the nervous system of the subject, and the intensity and duration of the shock must all have consideration. Griesinger, Amard and Daguin emphasize especially the results of pain, anxiety and shock, claiming that they are difficult or impossible to treat.

To the bride brought up under the old taboos, the sex experiences of early married life are apt to come as a shock, particularly when the previous sex experiences of her mate have been gained with women of another class. Indeed, so deeply has the sense of shame concerning the sexual functions been impressed upon the feminine mind that many wives never cease to feel a recurrent emotion of repugnance throughout the marital relationship. Especially would this be intensified in the case of sexual intercourse during the periods of gestation and lactation, when the girl who had been taught that the sexual functions existed only in the 
service of reproduction would see her most cherished illusions rudely dispelled. The effect of this long continued emotional state with its feeling of injury upon the metabolism of the female organism would be apt to have a detrimental effect upon the embryo through the blood supply, or upon the nursing infant through the mother's milk. There can be no doubt that anxiety, terror, etc., affect the milk supply, and therefore the life of the child.

The sixth dysgenic effect of the control by taboos is the rebellion of economically independent women who refuse motherhood under the only conditions society leaves open to them. The statistics in existence, though open to criticism, indicate that the most highly trained women in America are not perpetuating themselves. (3). Of the situation in England, Bertrand Russell said in I9I7: "If an average sample were taken out of the population of England, and their parents were examined, it would be found that prudence, energy, intellect and enlightenment were less common among the parents than in the population in general; while shiftlessness, feeble-mindedness, stupidity and superstition were more common than in the population in general . . Mutual liberty is making the old form of marriage impossible. while a new form is not yet developed." (4).

It must be admitted that to-day marriage and 


\section{TABOO AND GENETICS}

motherhood are subject to economic penalties. Perhaps one of the best explanations of the strength of the present struggle for economic independence among women is the fact that a commercial world interested in exchange values had refused to properly evaluate their social contribution. A new industrial system had taken away one by one their " natural " occupations. In the modern man's absorption in the life of a great industrial expansion, home life has been less insistent in its claims. His slackening of interest and attention, together with the discovery of her usefulness in industry, may have given the woman of initiative her opportunity to slip away from her ancient sphere into a world where her usefulness in other fields than that of sex has made her a different creat ure from the model woman of yesterday. These trained and educated women have hesitate to face the renunciations involved in a return to the home. The result has been one more factor in the lessening of eugenic motherhood, since it is necessarily the less strong who lose footing and fall back on marriage for support. These women wage-earners who live away from the traditions of what a woman ought to be will have a great deal of influence in the changed relations of the sexes. The answer to the question of their relation to the family and to a saner parenthood is of vital importance to society. 


\section{TABOO AND GENETICS 205 BIBLIOGRAPHY FOR CHAPTER IV}

I. Breckinridge, Sophonisba P. Social Control of Child Welfare. Publications of the American Sociological Society. Vol. XII, p. $23 \mathrm{f}$.

2. Davies, G. R. Social Environment. I49 pp. A. C. McClurg \& Co., Chicago, I9I7.

3. Popenoe, Paul. Eugenics and College Education. School and Society, pp. 438-44I. Vol. VI. No. I46. 4. Russell, Bertrand. Why Men Fight. 272 pp. The Century Co., N. Y., I9I7. 



\section{PART III}

THE SEX PROBLEM IN THE LIGHT OF MODERN PSYCHOLOGY

BY

PHYLLIS BLANCHARD, PH.D 



\section{CHAPTER I}

\section{SEX IN TERMS OF MODERN PSYCHOLOGY}

Bearing of modern psychology on the sex problem; Conditioning of the sexual impulse; Vicarious expression of the sexual impulse; Unconscious factors of the sex life; Taboo control has conditioned the natural biological tendencies of individuals to conform to arbitrary standards of masculinity and femininity; Conflict between individual desires and social standards.

An adequate treatment of the sex problem in society must necessarily involve a consideration of the sexual impulse in the individual members of that society. Recent psychological research, with its laboratory experiments and studies of pathology has added a great deal of information at this point. The lately acquired knowledge of the warping effect of the environment upon the native biological endowment of the individual by means of the establishment of conditioned reflexes, the discovery that any emotion which is denied its natural motor outlet tends to seek expression through some vicarious activity, and the realization of the fundamental importance of the unconscious factors in shaping emotional reactions, - - such formulations of behaviouristic and analytic psychology have 
thrown a great deal of light upon the nature of the individual sex life.

There are certain modifications of the erotic life which are explicable only when we recollect that under environmental influences situations which originally did not call up an emotional response come later to do so. This fact, which was first noted by Setchenov, was experimentally demonstrated by Pavlov and his students. (7). They found that when some irrelevant stimulus, such as a musical tone or a piece of coloured paper was presented to a dog simultaneously with its food for a sufficiently long period, the presentation of the tone or paper alone finally caused the same flow of saliva that the food had originally evoked. The irrelevant stimulus was named a food sign, and the involuntary motor response of salivary secretion was called a conditioned reflex to differentiate it from the similar response to the biologically adequate stimulus of food, which was termed an unconditioned reflex.

"The significance of the conditioned reflex is simply this, that an associated stimulus brings about a reaction; and this associated stimulus may be from any receptor organ of the body; and it may be formed of course not merely in the laboratory by specially devised experiments, but by association in the ordinary environment." (I). Thus it is evident that the 
formation of conditioned reflexes takes place in all fields of animal and human activity.

Watson has recently stated that a similar substitution of one stimulus for another occurs in the case of an emotional reaction as well as at the level of the simple physiological reflex response. (8). This means that when an emotionally exciting object stimulates the subject simultaneously with one not emotionaliy exciting, the latter may in time (or even after one joint stimulation) arouse the same emotional response as the former. Kempf considers this capacity of the emotion to become thus conditioned to other than the original stimuli " of the utmost importance in determining the selections and aversions throughout life, such as mating, habitat, friends, enemies, vocations, professions, religious and political preferences, etc." (5).

Just as Pavlov and his followers found that almost anything could become a food sign, so the study of neurotics has shown that the sexual emotion can be fixed upon almost any love object. For example, a single characteristic of a beloved person (e.g.,--eye colour, smile posture, gestures) can become itself a stimulus to evoke the emotional response originally associated only with that person. Then it happens that the affection may centre upon anyone possessing similar traits. In most psy- 
chological literature, this focussing of the emotion upon some particular characteristic is termed fetishism, and the stimulus which become capable of arousing the conditioned emotional response is called an erotic fetish. In extreme cases of fetishism, the sexual emotions can only be aroused in the presence of the particular fetish involved. Krafft-Ebing (6) and other psychopathologists describe very abnormal cases of erotic fetishism in which some inanimate object becomes entirely dissociated from the person with whom it was originally connected, so that it serves exclusively as a love object in itself, and prevents a normal emotional reaction to members of the opposite sex.

The development of romantic love has depended to a great extent upon the establishment of a wide range of stimuli capable of arousing the erotic impulses. As Finck has pointed out, this romantic sentiment is inseparable from the ideals of personal beauty. (3). As criteria of beauty he lists such characteristics as well-shaped waist, rounded bosom, full and red underlip, small feet, etc., all of which have come to be considered standards of loveliness because the erotic emotion has been conditioned to respond to their stimulation. Literature is full of references to such marks of beauty in its characters (Jane Eyre is almost the only wellknown book with a plain heroine), and is there- 
fore one of the potent factors in establishing a conditioned emotional reaction to these stimuli.

The erotic impulse may have its responses conditioned in many other ways than the building up of erotic fetishes. Kempf has observed that the affective reactions of the individual are largely conditioned by the unconscious attitudes of parents, friends, enemies and teachers. For instance, one boy is conditioned to distrust his ability and another to have confidence in his powers by the attitude of the parents. Similarly, the daughter whose mother is abnormally prudish about sexual functions will surely be conditioned to react in the same manner towards her own sexual functions, unless conditioned to react differently by the influence of another person. (5). Through the everyday associations in the social milieu, therefore, the erotic impulse of an individual may become modified in almost any manner.

Just as an emotional reaction may become conditioned to almost any other stimulus than the one which originally called it forth, so there is a tendency for any emotion to seek a vicarious outlet whenever its natural expression is inhibited. Were any member of the group to give free play to his affective life he would inevitably interfere seriously with the freedom of the other members. But the fear of arousing the dis- 
approval of his fellows, which is rooted in man's gregarious nature, inhibits the tendency to selfindulgence. "A most important factor begins to exert pressure upon the infant at birth and continues throughout its life," says Kempf. "It is the incessant, continuous pressure of the herd ... to conventionalize its methods of acquiring the gratification of its needs." (5). The emotions thus denied a natural outlet seek other channels of activity which have received the sanction of social approval.

It is obvious that the rigid social regulations concerning sexual activities must enforce repression of the erotic impulses more frequently than any others. The love which is thus denied its biological expression transmutes itself into many forms. It may reach out to envelop all humanity, and find a suitable activity in social service. It may be transformed into the love of God, and find an outlet in the religious life of the individual. Or it may be expressed only in language, in which case it may stop at the stage of erotic fantasy and day-dream, or may result in some really great piece of poetry or prose. This last outlet is so common that our language is full of symbolic words and phrases which have a hidden erotic meaning attached to them.

According to Watson, the phenomena seen in this tendency of emotions inhibited at one 
point to seek other outlets are too complex to be explained on the basis of conditioned reflex responses. All that we can say at present is that too great emotional pressure is drained off through whatever channel environmental and hereditary factors make possible. This vicarious mode of expression may become habitual, however, and interfere with a return to natural activities in a manner analogous to that in which the development of the erotic fetish often prevents the normal reaction to the original stimulus.

Because the conditioned emotional reactions and substitutions of vicarious motor outlets take place at neurological and physiological levels outside the realm of consciousness, they are called unconscious activities of the organism. There are many other unconscious factors which also modify the sex life of the human individual. The most fundamental of these are the impressions and associations of the infancy period, which may well be classed as conditioned reflex mechanisms, but are sufficiently important to receive separate consideration.

It is generally conceded by students of child psychology that the social reactions of the child are conditioned by the home environment in which the earliest and most formative years of its life are passed. It is not surprising, therefore, that the ideal of the opposite sex which 
the boy or girl forms at this time should approximate the mother or father, since they are the persons best loved and most frequently seen. The ideals thus established in early childhood are very often the unconscious influences which determine the choice of a mate in adult life. Or the devotion to the parent may be so intense as to prevent the transference of the love-life to another person and thus entirely prohibit the entrance upon the marital relation. Elida Evans has given some very convincing cases in illustration of these points in her recent book, "The Problem of the Nervous Child."

On the other hand, in those unfortunate cases where the father or mother is the object of dislike, associations may be formed which will be so persistent as to prevent the normal emotional reaction to the opposite sex in later years. This, too, results in the avoidance of marriage and the establishment of vicarious outlets for the sexual emotions, or less often in homosexual attachments or perversions of the sex life. Conditioned emotional reactions such as these play a dominant role in the social problem of sex, as will become apparent in succeeding chapters.

In addition to the influences which naturally act to condition the original sexual endowment of the individual, there are artificial forces 
which still further qualify it. The system of taboo control which society has always utilized in one form or another as a means of regulating the reproductive activities of its members, has set up arbitrary ideals of masculinity and femininity to which each man and woman must conform or else forfeit social esteem. The feminine standard thus enforced has been adequately described in Part II of this study. Dr Hinkle has also described this approved feminine type, as well as the contrasting masculine ideal which embodies the qualities of courage, aggressiveness, and other traditional male characteristics. From her psychoanalytic practice, Dr Hinkle concludes that men and women do not in reality conform to these arbitrarily fixed types by native biological endowment, but that they try to shape their reactions in harmony with these socially approved standards in spite of their innate tendencies to variation. (4).

The same conclusion might be arrived at theoretically on the grounds of the recent biological evidence of intersexuality discussed in Part I, which implies that there are no absolute degrees of maleness and femaleness. If there are no 100\% males and females, it is obvious that no men and women will entirely conform to ideals of masculine and feminine perfection. In addition to the imposition of these 
arbitrary standards of masculinity and femininity, society has forced upon its members conformity to a uniform and institutionalized type of sexual relationship. This institutionalized and inflexible type of sexual activity, which is the only expression of the sexual emotion meeting with social approval, not only makes no allowance for biological variations, but takes even less into account the vastly complex and exceedingly different conditionings of the emotional reactions of the individual sex life. The resulting conflict between the individual desires and the standards imposed by society has caused a great deal of disharmony in the psychic life of its members. The increasing number of divorces and the modern tendency to celibacy are symptomatic of the cumulative effect of this fundamental psychic conflict.

\section{BIBLIOGRAPHY FOR CHAPTER I}

I. Burnham, W. H. Mental Hygiene and the Conditioned Reflex. Ped. Sem. Vol. XXIV, Dec., I9I7, pp. 449-488.

2. Evans, Elida. The Problem of the Nervous Child. Kegan Paul \& Co., London, I920.

3. Finck, H. T. Romantic Love and Personal Beauty. Macmillan, N. Y., I89I.

4. Hinkle, Beatrice M. On the Arbitrary Use of the Terms "Masculine" and "Feminine." Psychoanalyt. Rev. Vol. VII, No. I, Jan., I920, pp. I5-30.

5. Kempf, E. J. The Tonus of the Autonomic Segments 


\section{TABOO AND GENETICS}

as Causes of Abnormal Behaviour. Jour. Nerv. \& Ment. Disease, Jan., I920, pp. I-34.

6. Krafft-Ebing, R. Psychopathia Sexualis. Fuchs, Stuttgart, I90\%.

7. Pavlov, J. P. L'excitation Psychique des Glandes Salivaires. Jour de Psychologie, Igro, No. 2, Pp. 97-II4.

8. Watson, J. B. Psychology from the Standpoint of a Behaviourist. Lippincott, Philadelphia, rgrg. 


\section{CHAPTER II}

\section{HOW OUR INSTITUTIONS FIT INDIVIDUAL SEX PSYCHOLOGY}

Social institutions controlling sex activities based on the assumption that all women are adapted to as well as specialized for reproduction; Neurotic tendencies which unfit women for marriage-the desire for domination; Sexual anæsthesia another neurotic trait which interferes with marital harmony; The conditioning of the sexual impulse to the parent ideal and the erotic fetish as factors which determine mating ; Homosexual tendencies and their part in the sex problem; The conflict between the desire for marriage and egoistic ambitions; The social regulations from the viewpoint of individual psychology.

The institutionalized forms of social control into which the old sex taboos have developed impose upon all members of the group a uniform type of sexual relationship. These socially enforced standards which govern the sex life are based upon the assumption that men and women conform closely to the masculine and feminine ideals of tradition. The emphasis is much more strongly placed on feminine con- 


\section{TABOO AND GENETICS}

formity, however; a great many sexual activities are tolerated in the male that would be unsparingly condemned in the female. Thus the sex problem becomes in large measure a woman's problem, not only because of her peculiar biological specialization for reproduction, which involves an enormous responsibility but also because her life has for so many generations been hedged in by rigid institutionalized taboos and prohibitions.

The traditional conception of marriage and the family relation implies that all women are adapted to as well as specialized for motherhood. In reality, if the biological evidence of intersexuality be as conclusive as now appears, there are many women who by their very nature are much better adapted to the activities customarily considered as pre-eminently masculine, although they are still specialized for childbearing. There is no statistical evidence of any high correlation between the sexual and maternal impulses. Indeed, a great many traits of human behaviour seem to justify the inference that these two tendencies may often be entirely dissociated in the individual life. Dr Blair Bell (as noted in Part I, Chapter III) believes that it is possible to differentiate women possessing a maternal impulse from those lacking such tendencies by the very anatomical structure. It is obvious that a woman endowed with a 
strong erotic nature requires a kind of sexual relationship different from one whose interests are predominantly in her children. And both the sexual and maternal types require different situations than the woman who combines the two instincts in her own personality for a normal expression of their emotional life.

According to social tradition, sexual activity (at least in the case of women) is to be exercised primarily for the reproduction of the group. Thus the institutions of marriage and the family in their present form provide only for the woman who possesses both the sexual and maternal cravings. Contraceptive knowledge has enabled a small number of women (which is rapidly growing larger) to fit into these institutions in spite of their lack of a desire for motherhood. There have been a few hardy theorists who have braved convention to the extent of suggesting the deliberate adoption of unmarried motherhood by women who are consumed by the maternal passion but have no strongly erotic nature. Whether their problem will be solved in this manner, only the course of social evolution in the future can show.

Besides the differences in natural instinctive tendencies which make it difficult for many women to fit into a uniform type of sexual relationship, modern society, with its less rigid 
natural selection, has permitted the survival of many neurotic temperaments which find marriage a precarious venture. The neurotic constitution, as Adler ( $I, 2)$ has pointed out, is an expression of underlying structural or functional organic deficiency. It is a physiological axiom that whenever one organ of the body, because of injury, disease, etc., becomes incapable of properly discharging its functions, its duties are taken over by some other organ or group of organs. This process of organic compensation, whereby deficiency in one part of the body is atoned for by additional labours of other parts, necessarily involves the nervous mechanism in ways which need not be discussed in detail here.

In children the process of compensation, with its formation of new nervous co-ordinations, is manifest in the inability to cope with their companions who have a better biological endowment. This gives rise to a feeling of inferiority from which the child tries to free itself by every possible means, ordinarily by surpassing in the classroom the playmates whom it cannot defeat on the playground. The feeling of inferiority continues throughout life, however, although the mechanism of physiological compensation may have become so perfected that the functioning of the organism is quite adequate to the needs of the environment. As a result, 


\section{TABOO AND GENETICS}

the ruling motive of the conduct becomes the desire to release the personality from this torturing sense of inability by a constant demonstration of the power to control circumstances or to dominate associates.

This abnormal will to power finds expression in the marital relationship in the desire for supremacy over the mate. The domineering husband is a familiar figure in daily life. The wife who finds it more difficult to rule her husband by sheer mastery achieves the same ends by developing a fit of hysterical weeping or having a nervous headache when denied her own way in family affairs.

By far the easiest way for the woman to satisfy her craving for power is the development of an interesting illness which makes her the centre of attention. The history of nervous disease furnishes many cases of neurosis where this uncontrollable longing for domination is the chief factor in the etiology of the illness. It is not at all unusual to meet wives who hold their husbands subservient to every whim because of "delicate nervous organizations" which are upset at the slightest thwarting of their wishes so that they develop nervous headaches, nervous indigestion, and many other kinds of sickness unless their preferences meet with the utmost consideration. This tendency often becomes a chronic invalidism, which, at 
the same time that it brings the longed-for attention, incapacitates the individual for sexual and maternal activities and makes the married life an abnormal and unhappy one.

Another more or less neurotic trait which acts as a cause of disharmony in the marital relationship is the sexual anæsthesia which is not at all uncommon in modern women. The absence of any erotic passion is held to be a matter of physiological makeup by many authorities, but it is probably more often due to the inhibition of natural tendencies in accordance with concepts built up by social tradition. In order to understand how social suggestion can have so powerful an effect upon the reactions of the individual, we must revert once more to the principles of behaviouristic psychology.

According to Watson (4), whenever the environmental factors are such that a direct expression of an emotion cannot occur, the individual has to have recourse to implicit motor attitudes. The best example in everyday life is probably seen in the case of anger, which can seldom be permitted to find an outlet in the natural act of striking, etc. It is apparent, however, in the facial expression and in a certain. muscular posture which can best be described as a " defiant" attitude. Another good example is the submissive attitude which often accompanies the emotion of fear. It is manifest in 
shrinking, avoiding movements, sometimes of the whole body, but more often of the eyes or some other special organ.

"In the sphere of love," Watson remarks, "there are numerous attitudes as shown by the popular expressions lovelorn, lovesick, tenderness, sympathy. More fundamental and prominent attitudes are those of shyness, shame, embarrassment, jealousy, envy, hate, pride, suspicion, resentment, anguish, and anxiety." (4.)

The significant fact is that these attitudes function by limiting the range of stimuli to which the person is sensitive. The attitude of shame concerning their sexual functions, which has been impressed upon women as a result of ages of thinking in harmony with taboo standards, thus is able to prevent the normal biological response to a situation which should call out the emotions of love. In women who have an unstable nervous system this shameful feeling often results in a definite physiological shrinking from the physical manifestations of sexuality and renders the individual insensitive to all erotic stimulation.

This attitude of shame in connection with the love life came into existence as a socially conditioned emotional reaction set up under the influence of the traditional ideal of the " model woman" who was pictured as a being of un- 


\section{TABOO AND GENETICS}

earthly purity and immaculacy. It has been passed on from generation to generation through an unconscious conditioning of the daughter's attitude by suggestion and imitation to resemble that of the mother. Thus it happens that although an increasing amount of liberty, both social and economic, and a more rational and scientific understanding of the womanly nature, have quite revoked this ideal in theory, in actual practice it still continues to exert its inhibitory and restrictive influence.

Because the standardized family relationship involves so much more radical a readjustment in the life of woman than of man, it has almost always been the feminine partner who has taken refuge in neurotic symptoms in order to escape the difficulties of the situation. After the marriage ceremony, the man's life goes on much as before, so far as his social activities are concerned, but woman takes up the new duties connected with the care of the home and her child-bearing functions. Moreover, the sexual life of woman is in many ways more complex than that of man. She has been subjected to more repressions and inhibitions, and as a result there has been more modification of her emotional reactions in the field of love. This greater complexity of her love life makes adaptation to marriage more problematical in the case of woman. 
Although the neurotic tendencies of modern women have been an important factor for the production of disharmony in the family life, there are certain variations of the individual sex life which are more universally significant. The conditioned emotional reactions which environmental influences have built up around the sexual impulse of each member of society invariably determine the choice of the mate and give rise to extremely complicated problems by the very nature of the selective process. It is largely a matter of chance whether the mate chosen in accordance with the ideals of romantic love and because of some fascinating trait which acts as an erotic fetish or in conformity with a parental fixation will prove a congenial companion through life.

But the complexity of the situation lies in the fact that the erotic impulses may become conditioned to respond to an indefinite number of substituted stimuli. For example, the parental fixation may become reconditioned by focussing upon some special characteristic of the father or mother, which becomes an erotic fetish. If the mate is selected on the basis of this fetishistic attraction, he (or she) may prove to be so unlike the parent in other respects as to lose all the affection which was originally inspired. A concrete illustration of these conflicting emotional reactions is the case of the girl who declared 


\section{TABOO AND GENETICS}

that she feared her fiancé as much as she loved him, but felt that she must marry him nevertheless. An investigation showed that her almost compulsive feeling about her lover was due to the fact that his gestures and manner of regarding her, in fact his whole bearing, reminded her of her dead father, while in other respects he was totally repugnant to her because his character traits were so far removed from those of her father ideal.

The conflict between the parental ideal and other phases of the sexual impulse is even more pronounced in men than in women, for two reasons. " In the first place, the mother plays by far the largest part in the life of her children, so that the son's fixation upon her is necessarily more intense than the daughter's affection for the father. Yet on the other hand, the sexual desire of the male is more easily aroused than that of the female, and is more apt to centre upon some member of the opposite sex who possesses certain physical attractiveness but is not at all like the mother ideal. Thus it happens that men often enshrine on their hearthstone the woman who approximates the worshipped mother, while they seek satisfaction for their erotic needs outside the home. In other words, in the masculine psyche there is often a dissociation of the sexual impulse in its direct manifestations and the sentiment of love in its 
more idealistic aspects. This partially explains the fact that it is possible for a man to be " unfaithful" to his wife while actually loving her devotedly all the time.

A different solution of the unconscious conflict between the mother fixation and the sexual desires at lower levels is seen in those cases in which the man impulsively marries the woman who has this transient attraction for him. When the first passion of such an alliance has worn away, there is no lasting bond to take its place, and the man must find solace in some such way as an intimate friendship with a woman who recalls the maternal impressions of his childhood. A famous example of this is found in the beautiful affection of Auguste Comte for his idolized Clotilde de Vaux. Although 'Comte was bound to a woman whom he had married in the flush of erotic desire and whom he found entirely uncongenial, Clotilde became the inspiration of his later life, and held his affection without the aid of any material bond because she so closely resembled the dead mother whom he adored.

It is evident that the selection of a mate who is erotically attractive, but proves to be very similar to a parent who was disliked instead of loved, is as unfortunate as the choice of a partner who is utterly unlike a beloved father or mother. Indeed, when all the possible complications 


\section{TABOO AND GENETICS}

are clearly visualized, taking into account the numerous ways in which the sexual emotions can be modified, it is plain that these unconscious factors which determine the choice of a mate are not always conducive to a happy married life.

Quite recently the tendency to homosexuality has been emphasized as an important factor in the psychological problem of sex. At the International Conference of Medical Women (New York, I9I9) it was stated that homosexual fixations among women are a frequent cause of female celibacy and divorce. This view was upheld by such authorities as Dr. Constance Long of England, and other prominent women physicians. Although a certain percentage of female homosexuality is congenital, it is probable that by far the largest part is due to a conditioning of the sexual impulse by the substitution of members of the same sex as the erotic stimulus in place of the normal response to the opposite sex.

This substitution is facilitated by certain facts in the social life of women. The frequent lack of opportunity to be with men during adolescent school days, and a certain amount of taboo on male society for the unmarried woman, are in direct favour of the establishment of homosexual reactions. There is also an increasing sex antagonism, growing out of woman's 
long struggle for the privilege of participating in activities and sharing prerogatives formerly limited to men, which acts as an inhibitory force to prevent the transference of the sexual emotion to its normal object in the opposite sex. Moreover, the entrance of woman into a manner of living and lines of activity which have heretofore been exclusively masculine, has brought out certain character traits which in other times would have been repressed as incompatible with the social standards of feminine conduct, but which are conducive to the formation of homosexual attachments, since the qualities admired in men can now be found also in women.

In this connection the term homosexuality is used very loosely to denote any type of emotional fixation upon members of the same sex which is strong enough to prevent a normal love life with some individual of the opposite sex. Among American women, at least, this tendency is seldom expressed by any gross physical manifestations, but often becomes an idealized and lofty sentiment of friendship. It is abnormal, however, when it becomes so strong as to prevent a happy married life.

The tendency of emotions to seek a vicarious outlet must also be considered in any inclusive attempt to explain the homosexual attachment of women. The woman who, on account of lack of attraction for men or for any other 
reason, is denied the normal functioning of the love life in marriage, is forced to find some other expression for her erotic emotions, and it is only natural that she should find it in an affection for other women. Again, the voluntary celibacy of a large class of modern women, who prefer to retain their economic independence rather than to enter into family life, also necessitates finding vicarious emotional activities. Whenever their work throws a number of these women into constant association, it is almost inevitable that homosexual attachments will spring up.

We meet all these types of homosexual fixations in daily life. The college girl who is isolated from men for four years has her sworn comrade among the girls, and is sure that she will never marry but will love her chum always. Very often it is some time after she leaves college before she begins to take an interest in male companionship. The young professional woman looks up to the older woman in her line of work with the same admiration for her courage and brilliancy that used to be reserved for the husband alone in the days when women were permitted only a strictly feminine education and occupation. The business woman refuses to give up her high salaried position for marriage, and consoles herself with her feminine friends. These are the common manifestations characteristic of female homosexuality. As has been 
suggested, the term is loosely applied to such cases as these, but the tendency of recent psychological literature is to consider them as highly sublimated expressions of this tendency. As has been intimated, the modern woman who has entered into the economic competition is often reluctant to abandon this activity for the responsibilities of wifehood and motherhood, which involve a withdrawal from the business world. Just as the materialistic rewards of economic activities often prove more attractive than the emotional satisfactions of family life, so, too, the intellectual ambitions of the professional woman may deter her from the exercise of her reproductive functions. Thus the egoistic and individualistic tendencies which modern social organization fosters in the personality of its feminine members makes them unwilling to sacrifice their ambitious plans in the performance of their natural biological functions.

In the present speeding up of competition, the entrance upon family life becomes almost as burdensome to man as to woman, although in a different manner. Free as he is from the biological responsibilities connected with childbearing which fall to a woman's lot, he finds the economic responsibilities which the care of children entails equally grilling. His choice of a profession can no longer be decided by his own preferences, but must be determined by 


\section{TABOO AND GENETICS}

the economic returns. He can never afford to sacrifice financial gain for personal recognition, because of his obligation to provide for his family. Thus it happens that marriage often presents a situation in which no outlet for personal ambitions is possible and the egoistic desires and emotions must be sternly repressed. There is therefore an increasing hesitancy on the part of the men of to-day to assume responsibilities so grave and involving so much personal sacrifice.

It is evident from even such a casual inquiry as this, that there are many facts of individual psychology which have not been taken into account by society in the development of the mores which govern the sexual relationships of its members. The traditional institution of the family, which would shape all women into model wives and mothers, has neglected to consider the fact that not all women are biologically adapted for these particular activities. The choice of a mate which is determined by irrational and unconscious motives may or may not prove to be a wise selection, as we have seen in the course of our discussion. Most significant of all for the social problem of sex, is the overwhelming tendency to individuation which is making both men and women frankly question whether marriage and parenthood are worth while when they involve so much personal sacrifice. 


\section{TABOO AND GENETICS}

From the viewpoint of psychology, we may briefly summarize the whole situation by saying that society has imposed upon its members a uniform and inflexible type of sexual relationships and reproductive activities with a total disregard of individual differences in its demand for conformity to these traditions. When the infinite number of variations and modifications possible in the sexual life of different individuals is taken into consideration, it is obvious that there must be a certain disharmony between personal inclinations and social standards. Because the power of the group control is very great, its members usually repress emotions which are not in accord with its regulations, and shape their conduct to meet with its approval. If such a restriction of the personality and emotional life of the individual is necessary for the welfare of the whole race and for social progress, its existence is entirely justified. It is our next task, therefore, to determine in what respects a rigid and irrational social control is conducive to human betterment, and wherein, if at all, it fails to achieve this purpose.

\section{BIBLIOGRAPHY FOR CHAPTER II}

I. Adler, Alfred. The Neurotic Constitution. Moffat, Yard, N. Y., I917. (Kegan Paul \& Co., I92I.)

2. Adler, Alfred. A Study of Organic Inferiority and Its Psychic Compensation. Nervous \& Mental Disease Pub. Co., N. Y., Igr7. 


\section{TABOO AND GENETICS}

3. Blanchard, P. A Psychoanalytic Study of Auguste Comte. Am. Jour. Psy., April, rgi8.

4. Watson, J. B. Psychology from the Standpoint of a Behaviourist. Lippincott, Philadelphia, IgIg. 


\section{CHAPTER III}

DYSGENIC NATURE OF CERTAIN FACTORS OF SEX PSYCHOLOGY AND NECESSITY FOR A SOCIAL THERAPY

Mating determined by unconscious psychological motives instead of eugenic considerations; Some of the best male and female stock refusing marriage and parenthood; The race is reproduced largely by the inferior and average stocks and very little by the superior stock ; As a therapeutic measure, society should utilize psychological knowledge as a new method of control ; Romantic love and conjugal love-a new ideal of love ; The solution of the conflict between individual and group interests.

From the viewpoint of group welfare, the present psychological situation of human reproductive activities undoubtedly has its detrimental aspects. As we have seen, the choice of a mate is determined by irrational motives which lie far below the levels of consciousness. These unconscious factors which govern sexual selection far outweigh the more rational considerations of modern eugenic thought. The marks of personal beauty around 
which romantic love centres and which there fore play a prominent part in mating are not necessarily indicative of physical and mental health that will insure the production of sound offspring. The modern standards of beauty (at least in so far as feminine loveliness is concerned) have gone far from the ancient Grecian type of physical perfection. Influenced perhaps by the chivalric ideals of " the lady," the demand is rather for a delicate and fragile prettiness which has come to be regarded as the essence of femininity. The robust, athletic girl must preserve this "feminine charm" in the midst of her wholesome outdoor life, else she stands in great danger of losing her erotic attraction.

Surface indications of the truth of this statement are easily discovered. The literature which before the war ran riot with athletic heroines pictured them with wind-blown hair and flushed cheeks receiving the offer of their male companion's heart and hand. The golf course or the summer camp was simply a charming new setting for the development of the eternal love theme. Even fashion has conspired to emphasize the feminine charm of the girl who goes in for sports, as a glance at the models of bathing costumes, silken sweaters, and graceful "sport" skirts plainly reveals.

Just as the love which is directed in accordance with an emotional reaction conditioned to 
respond to some erotic fetishism or to a parent ideal may be productive of individual unhappiness, so it is also entirely a matter of chance whether or not it leads to a eugenic mating. Like romantic love, it is quite as apt to focus upon a person who does not conform to eugenic ideals as upon one who does. The mate selected upon the basis of these unconscious motives is very likely to bequeath a neurotic constitution or an otherwise impaired physical organism to the offspring of the union, since those possibilities were not taken into consideration in making the choice.

It becomes apparent that while certain forces in the life of the individual and in the social inheritance have united to condition the emotional reactions of the sex life, these conditionings have not always been for the benefit of the race. Indeed, it would almost seem that society has been more concerned with the manner of expression of the love life in the individual members than in its effects upon the next generation. In its neglect or ignorance of the significance of artificial modifications of the emotions, it has permitted certain dysgenic influences to continue in the psychic life of generation after generation, regarding with the utmost placidity a process of sexual selection determined by irrational and irresponsible motives. 
The most potent dysgenic influence in the present phase of the sex problem is the conflict between the interests of the individual and the group regulations. The traditional type of marriage and family life has a cramping effect upon the personal ambitions which lessens its attractiveness materially. The enterprising young business or professional man has no desire to restrict his opportunities by the assumption of the responsibilities that accompany family life. He must be free to stake all his resources on some favourable speculation without the thought that he cannot take chances on impóverishing his wife and children. Or if he has professional aspirations, he must be able to take the long difficult pathway of scientific research with no anxiety about the meagre salary that is insufficient for the support of a home. Thus the most vital and aggressive male stocks as well as the most highly intelligent tend to avoid the hampering effects of family life, and their qualities are often lost to the next generation, since even if they marry they will feel that they cannot afford offspring.

As women enter more and more into the competition for economic and social rewards, this becomes equally applicable in their case. Indeed, it would be strange were there not an even greater tendency to shun the ties of family life on the part of ambitious women than of 
men, since it involves greater sacrifices in their case on account of their biological specialization for motherhood. It appears, therefore, that we are losing the best parental material for the coming generations on both the paternal and maternal sides. Thus the conflict between the egoistic desires and the social institution of the family is segregating just those energetic, successful individuals from whom the race of the future should spring if we hope to reproduce a social organism capable of survival in the intergroup struggle.

If it be true that the best stock, both male and female, for various reasons refuses to assume the duty of reproduction, the group will necessarily be replaced from individuals of average and inferior (but not superior) eugenic value. Even within these limits there is at present no conscious eugenic selection, and the irrational and unconscious motives which govern sexual selection at the present time may induce the choice of a mate from among the weaker individuals. Once again it becomes a matter of chance whether or not the matings prove to be for the welfare of the group and of the race.

It might be contended that the very fact that certain individuals withdraw from reproductive activities is sufficient proof of their lack of normal emotional reactions adapting them to the performance of those functions. But a 
clearer insight shows that the group standards permit the exercise of the reproductive activities only in accord with arbitrary regulations which have coalesced in the institutions of marriage and the family. These institutions have been developed to fit a definite ideal of manhood and womanhood which grew up out of a manner of thinking in accord with taboo control and ignorant superstitions rather than in harmony with the actual facts of the situation. Now that we are facing reality and trying to rationalize our thinking, we find that the variation from these masculine and feminine ideals does not necessarily imply biological or psychological abnormality, since the ideals were themselves established without reference to biological and psychological data.

The traditional marriage and family arrangement tends to enforce a selection of individuals who conform most nearly to these artificial types as parents for the succeeding generations. It is not at all certain that such a selection is advantageous to the group. It would seem rather that in so complex a social system as that of the present day with its increasing division of labour on other than purely sexual distinctions, we need a variety of types of individuals adapted to the varied activities of modern life.

If society is to successfully meet the present 
situation it must utilize its psychological insight to remedy conditions which are obviously dysgenic and detrimental to the welfare of the race. If the egoistic and highly individualized modern man and woman are induced to sacrifice personal ambitions in the interests of reproduction, for instance, it will only be because society has learned to turn those same egoistic impulses to its own ends. This will never be accomplished by the forces of tradition or by any such superimposed method of control as conscription for parenthood. There is too much of a spirit of freedom and individual liberty in the social mind to-day for any such measure to meet with success. The same spirit of freedom which formerly burst the bonds of superstition and entered into the world of science is now as impatient of restraint of its emotional life as it formerly was of restriction of its intellectual search for the truth.

Therefore society can no longer depend upon taboo standards crystallized into institutionalized forms as a means of control. It must appeal to more rational motives if it expects to have any degree of influence over its most intelligent and energetic members. Only when the production of eugenic offspring brings the same social approval and reward that is meted out for other activities will the ineradicable and irrespressible egoistic desires that now 


\section{TABOO AND GENETICS}

prevent individuals from assuming the responsibilities of family life be enlisted in the very cause to which they are now so hostile. When the same disapproval is manifested for the shirking of reproductive activities by the eugenically fit that is now directed toward lack of patriotism in other lines, the number of voluntary celibates in society will be materialy decreased.

The greatest triumph of society in the manipulation of the sexual and reproductive life of its members will come when it is able to condition the emotional reaction of the individual by the substitution of the eugenic ideal for the parental fixation and to focus the sentiment of romantic love upon eugenic traits. When this is accomplished, the selection of the mate will at least be favourable for racial regeneration even if individual disharmonies are not entirely eliminated. That there are great difficulties in the way of this accomplishment may be admitted at the outset. The conditioned responses to be broken down and replaced are for the most part formed in early childhood, and have had a long period in which to become firmly impressed upon the organism. But psychological experiments have proven that even the best established conditioned reactions can be broken down and others substituted in their place, so that the situation is not so hope- 


\section{TABOO AND GENETICS}

less. When we recollect that for ages the traditional ideals of masculinity and femininity have been conditioning the emotional life of men and women to respond to their requirements with a remarkable degree of success, there is ground for the belief that the same forces of suggestion and imitation may be turned to more rational ends and utilized as an effective means of social therapy.

If we are to have a more rationalized form of social control, the it will undoubtedly take into consideration the necessity of forming the socially desirable conditionings of the emotional life. The importance of the emotional reactions for social progress has been very well summarized by Burgess, who says that emotion can be utilized for breaking down old customs and establishing new ones, as well as for the conservation of the mores. Society can largely determine around what stimuli the emotions can be organized, this author continues, and the group has indeed always sought to control the stimuli impinging upon its members. One policy has been to eliminate objectionable stimuli, as in the outlawing of the saloon. The other is to change the nature of the affective response of the individual to certain stimuli in the environment where the natural or organic responses would be at variance with conduct considered socially desirable. (3). 


\section{TABOO AND GENETICS}

Modern psychological knowledge enables us to understand the mechanism of this last method of social control as the building up of the conditioned emotional response. If our civilization is to endure it must learn to apply this method of control to the sex life of the individual so that reproduction will fall to the lot of the most desirable eugenic stock instead of being left to the workings of chance as it is at the present time.

From the viewpoint of individual psychology, one of the principal problems of the erotic life is to find a smooth transition from the romantic love of the courtship period to the less ethereal emotions of the married state. Indirectly, this is also socially significant, because of the overwhelming effect of the home environment in shaping the reactions of the next generation. As a rule, only the children who have grown up in a happy and wholesome atmosphere of sincere parental comradeship and affection can have an entirely sane and healthy reaction to their own erotic functions in later years.

Although romantic love in its present expression may often lead to uncongenial marriages and even involve dysgenic mating, its æsthetic and refining influences are such as to make it desirable in spite of these drawbacks. Its influence upon literature has been noted by Bloch (2) while its potency in the formation of 
a deep and tender feeling between men and women has been elaborately discussed by Finck (4). Thus it is evident that its individual and social advantages more than balance its disadvantages.

Unfortunately, with the entrance into the marital relationship and the release of the erotic emotion into natural channels so that it no longer seeks the vicarious outlets which were partly supplied in the idealization of the lovers, there is a tendency for this romantic element to fade from their affection. The conjugal affection which replaces it is built on quite other foundations. It is not composed of day dreams about the beloved, but is wrought out of mutual interests, of joys and sorrows shared together, of the pleasure of unrestricted companionship, and of the common care of offspring. The danger lies in the possibility that these foundations for conjugal love will not have been lain by the time that romantic sentiments begin to grow dim. It is this crisis in the married life which seems disappointing in the afterglow of the engagement and honeymoon.

Of late there have been attempts to build up a new conception of love which shall incorporate the best features of romantic love and at the same time make the transition to the conjugal affection less difficult. This new conception has grown up through the increasing 
freedom of women and the constant association of the sexes in the educational and business world as well as in the social life. This free companionship of men and women has done much to destroy the illusions about each other which were formerly supposed to be so necessary a component of romantic love, but it has also created the basis for a broader sympathy and a deeper comradeship which is easily carried over into the married relation.

The new ideal of love which is being thus developed combines complete understanding and frankness with erotic attraction and the tenderness of romanticism. It implies a type of marital relationship in which there is preservation of the personality and at the same time a harmony and union of interests that was often absent from the old-fashioned marriage, when the wife was supposed to be more limited in her interests than her husband. It may well be that the evolution of this new ideal of love, which grants personal autonomy even within the marriage bond, will solve a great deal of the present conflict between the individualistic impulses and the exercise of the erotic functions as permitted by the group.

It is, of course, an open question as to how far the interests of the individual and the group can be made to coincide. Group survival demands that the most vital and intelligent 


\section{TABOO AND GENETICS}

members shall be those to carry on the reproductive functions. Therefore from the social viewpoint, it is quite justified in setting up the machinery of social approval and in establishing emotional attitudes by this means that will insure that this takes place. On the other hand, it may be that the individuals who will be thus coerced will be as rebellious against new forms of social control as they are restless under the present methods of restraint.

If we free curselves from a manner of thinking induced by inhibitions developed through ages of taboo control, and look at the problem rationally, we must admit that the chief interest of society would be in the eugenic value of the children born into it. At the present time, however, the emphasis seems to be chiefly upon the manrer of birth, that is, the principal concern is to have the parents married in the customary orthodox fashion. Only in view of the necessities of the recent war have the European nations been forced to wipe out the stain of illegitimacy, and in America we are still blind to this necessity. Only Scandinavia, under the leadership of such minds as Ellen Key's, was roused to this inconsistency in the mores without external pressure, and enacted legislation concerning illegitimacy which may well serve as a model to the whole world. The main points of the Norwegian Castberg bill are as follows: The child whose 
parents are unmarried has a right to the surname of the father, and the right of inheritance from a propertied father; the court has full power to clear up the paternity of the child; the man is held responsible for the child's support even if other men are known to have had intercourse with the mother. In order to discourage immorality in women for the purpose of blackmailing wealthy men, the mother is also compelled to contribute to the child's support. (I).

No psychologist of discernment, in insisting on eugenic standards rather than a marriage certificate as the best criterion for parenthood would encotrage any tendency to promiscuous mating. The individual suffering involved in such a system of sexual relationships would be too great to permit its universal adoption even if it should be found to have no deleterious social effects. But the very fact that transient mating does involve so much human agony, especially on the part of the woman, is all the more reason why it is needless to add artificial burdens to those already compelled by the very nature of the emotional life.

The study of child psychology, too, would tend to discourage any general tendency to temporary sexual relationships. Modern research has shown that nothing is more necessary for the normal development of the child's 
emotional life than a happy home environment with the presence of both father and mother. Only in these surroundings, with the love of both parents as a part of the childhood experience, can the emotional reactions of the child be properly conditioned to respond to the social situations of adult life.

In one respect, at least, society can do a great deal to better the existing situation, and to solve the struggle between the individual and group interests. At the same time that it endeavours to set up emotional responses that shall be conducive to eugenic mating and to a happy love life, as well as for the welfare of the child, it should also leave a wide margin of personal liberty for the individuals concerned to work out a type of sexual relationship which is in harmony with their natural inclinations. The institution of monogamy is too deeply founded in the needs of the individual and of the child to suffer from this increase in freedom and responsibility. Were it so frail a thing as to need the protection of the church and state as well as public opinion to insure its survival, it would be so little adapted to the needs of humanity that it might better disappear.

There are no indications that there would be any wider deviation from the monogamous relationship were variations frankly recognized that now take place in secret. By its present 
attitude, society is not accomplishing its purpose and preventing all sexual relationships except those which conform to its institutionalized standards. It is merely forcing what should be always the most dignified of human relationships into the shamefulness of concealment and furtiveness. Moreover, because it visits its wrath on the child born of unions which are not strictly conventionalized, it prevents the birth of children from mothers who might be of great eugenic value, but whon fear of social disapproval keeps from the exercise of their maternal functions but not of their sexual activities.

In the final analysis, it will probably be demonstrated that for a certain type of personality there can be no compromise which will resolve the conflict between the egoistic inclinations and the interests of the group. For those whose deepest desires are so out of harmony with the social life of the times there is no alternative but to sacrifice their personal desires or to forfeit the pleasure of feeling in complete rapport with their fellows. In such natures, the ultimate course of conduct will be determined by the relative strengths of the individualistic and gregarious impulses, other things being equal. In some instances this will mean the choice of a line of conduct out of harmony with the general trend of group life; in others, 


\section{TABOO AND GENETICS}

it will mean the repression of personal inclinations and conformity to social standards.

For the majority of people, however, it is likely that a more rational form of social control, freed from the long ages of taboo restrictions, and based upon accurate biological and psychological knowledge, will solve the disharmony between the individual and the group to a great extent. Such a rationalization will take into account the value of a new ideal of love which shall be built up from a sane relationship between the sexes and in accordance with eugenic standards. It will also grant a great deal of personal autonomy in the determination of sexual relationships in so far as this can be correlated with the welfare of the children of the race. Last of all, it will attempt to condition the emotional reactions to respond to stimuli which shall insure eugenic mating naturally and without the intervention of legislation.

Unless modern civilization can set up some such form of rational control for the sexual and reproductive life of its members, the present conflict between individuation and socialization will continue and the dysgenic factors now operative in society will steadily increase. In the end, this internal conflict may become so powerful as to act as an irresistible disintegrating force that will shatter the fabric of modern 


\section{TABOO AND GENETICS 255}

social organization. Only the evolution of a rationalized method of control can avert this social catastrophe.

\section{BIBLIOGRAPHY FOR CHAPTER III.}

I. Anthony, Katharine. Feminism in Germany and Scandinavia. Henry Holt, N. Y., IgI5.

2. Bloch, Ivan. Sexual Life of Our Time. Rebman, London, 1908.

3. Burgess, E. W. The Function of Socialization in Social Evolution. Univ. Chicago Press, I9I6.

4. Finck, H. T. Romantic Love and Personal Beauty. Macmillan, N. Y., I8gI. 




UNIVERSITY OF CALIFORNIA LIBRARY

Los Angeles

This book is DUE on the last date stamped below.

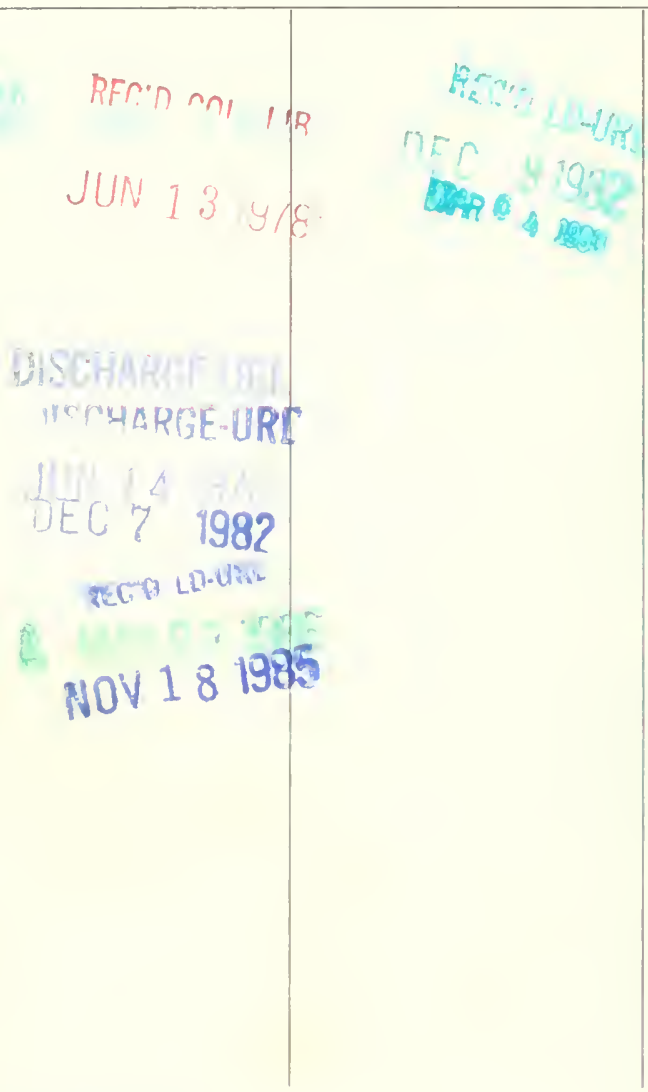

Form L9-Series 4939
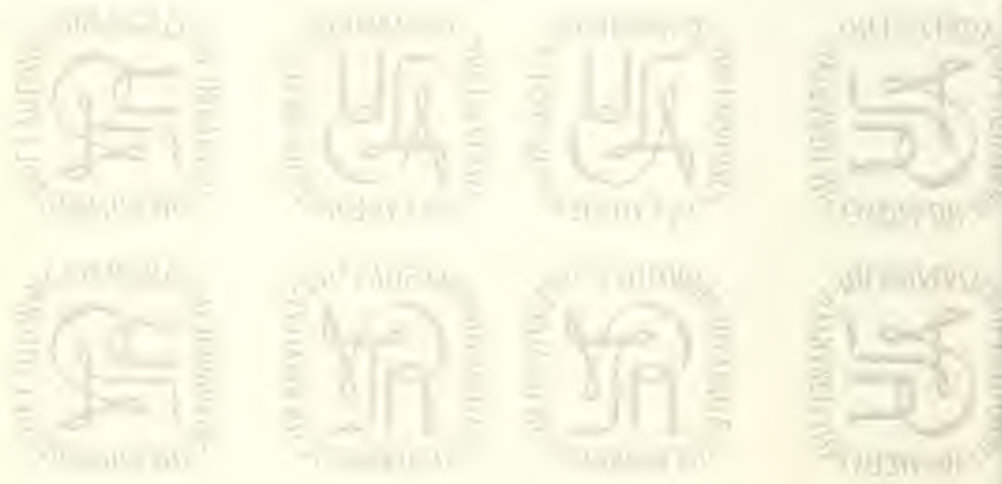


\section{tB $\|_{3}||||||||||||||||||||||$}
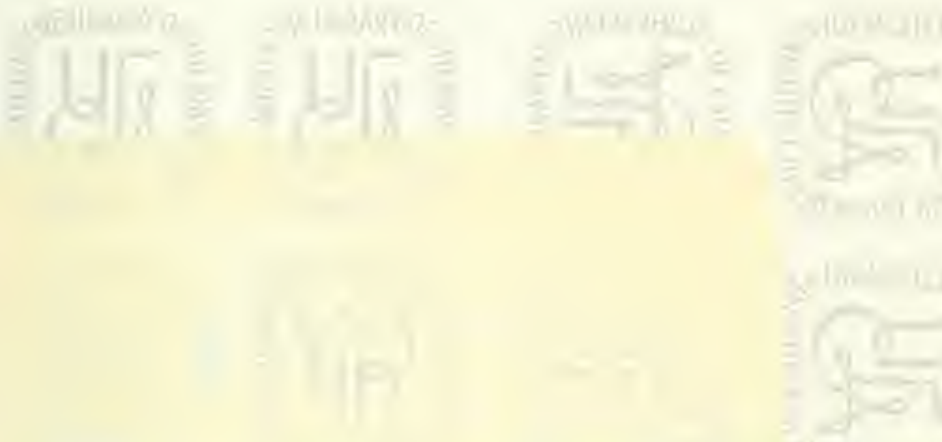

UC SOUTHERN REGIONAL LIBRARY FACILITY

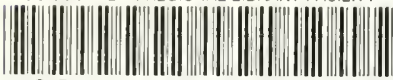

AA 0003906435
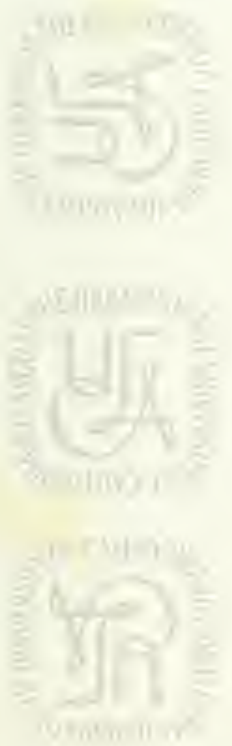
